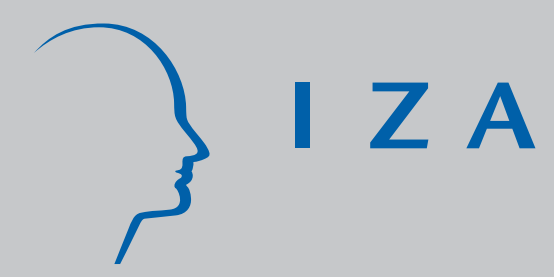

IZA DP No. 2387

Industry Wage Differentials, Unobserved Ability, and Rent-Sharing: Evidence from Matched Worker-Firm Data, 1995-2002

Robert Plasman

François Rycx

Ilan Tojerow

October 2006 


\title{
Industry Wage Differentials, Unobserved Ability, and Rent-Sharing: Evidence from Matched Worker-Firm Data, 1995-2002
}

\author{
Robert Plasman \\ Free University of Brussels, DULBEA \\ François Rycx \\ Free University of Brussels, DULBEA \\ and IZA Bonn \\ Ilan Tojerow \\ Free University of Brussels, DULBEA \\ and IZA Bonn
}

Discussion Paper No. 2387

October 2006

\author{
IZA \\ P.O. Box 7240 \\ 53072 Bonn \\ Germany
}

Phone: +49-228-3894-0

Fax: +49-228-3894-180

Email: iza@iza.org

Any opinions expressed here are those of the author(s) and not those of the institute. Research disseminated by IZA may include views on policy, but the institute itself takes no institutional policy positions.

The Institute for the Study of Labor (IZA) in Bonn is a local and virtual international research center and a place of communication between science, politics and business. IZA is an independent nonprofit company supported by Deutsche Post World Net. The center is associated with the University of Bonn and offers a stimulating research environment through its research networks, research support, and visitors and doctoral programs. IZA engages in (i) original and internationally competitive research in all fields of labor economics, (ii) development of policy concepts, and (iii) dissemination of research results and concepts to the interested public.

IZA Discussion Papers often represent preliminary work and are circulated to encourage discussion. Citation of such a paper should account for its provisional character. A revised version may be available directly from the author. 


\begin{abstract}
Industry Wage Differentials, Unobserved Ability, and Rent-Sharing: Evidence from Matched Worker-Firm Data, 1995-2002*

This paper investigates inter-industry wage differentials in Belgium, taking advantage of access to a unique matched employer-employee data set covering the period 1995-2002. Findings show the existence of large and persistent wage differentials among workers with the same observed characteristics and working conditions, employed in different sectors. The hypothesis that workers with better unmeasured abilities are over-represented in high-wage sectors may not be rejected on the basis of Martins' (2004) methodology. However, the contribution of this explanation to the observed industry wage differentials appears to be limited. Further results show that ceteris paribus, workers earn significantly higher wages when employed in more profitable firms. Our instrumented wage-profit elasticity stands at 0.063 and Lester's range of pay is about 41 per cent of the mean wage. This rent-sharing phenomenon accounts for a large fraction of the industry wage differentials. We find indeed that the magnitude, dispersion and significance of industry wage differentials decreases sharply when controlling for profits.
\end{abstract}

JEL Classification: D31, J31, J41

Keywords: industry wage differentials, unobserved heterogeneity, rent-sharing, matched employer-employee data, quantile regressions

Corresponding author:

Ilan Tojerow

Department of Applied Economics (DULBEA)

Free University of Brussels

50 Avenue F.D. Roosevelt

B-1050 Brussels

Belgium

E-mail: itojerow@ulb.ac.be

\footnotetext{
* This paper is produced as part of the National Bank of Belgium (NBB) Joint Research Project on Price and Wage Rigidities in an Open Economy. Financial support from the NBB is gratefully acknowledged. We would like to thank the researchers of the NBB and the other participants of this joint research project for their many helpful comments and suggestions. We are also most grateful to Statistics Belgium for giving access to the Belgian Structure of Earnings Survey and Structure of Business Survey. The usual disclaimer applies.
} 


\section{TABLE OF CONTENTS}

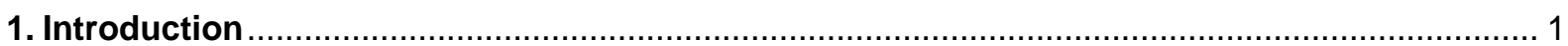

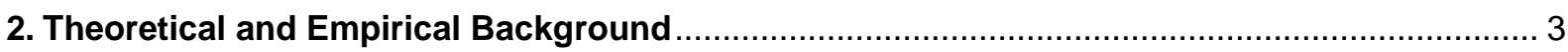

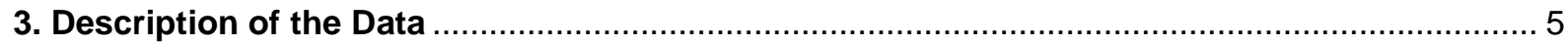

4. Magnitude, Dispersion and Stability of Industry Wage Differentials ................................... 11

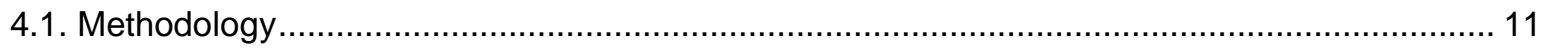

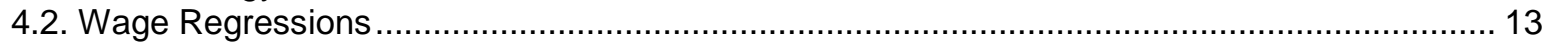

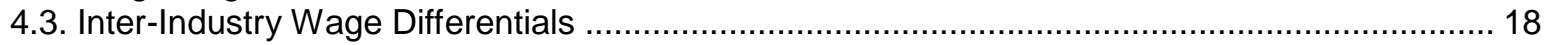

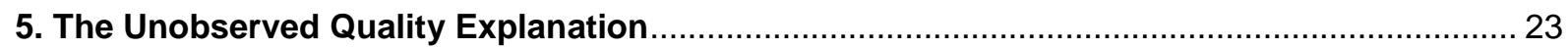

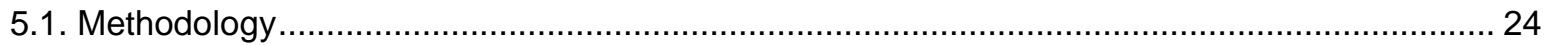

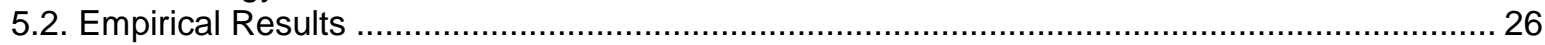

6. Industry Wage Differentials and Sectoral Heterogeneity in 'Ability to Pay' ............................. 28

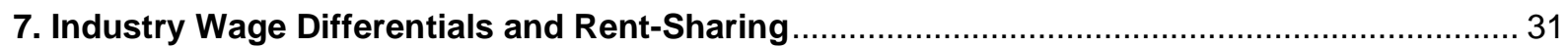

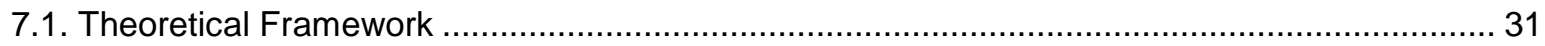

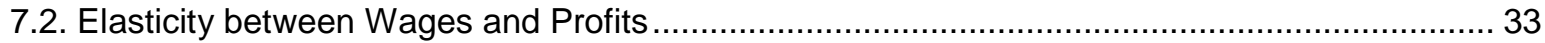

7.3. Industry Wage Premia Before and After Controlling for Rent-Sharing ................................... 37

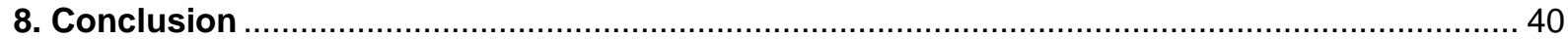

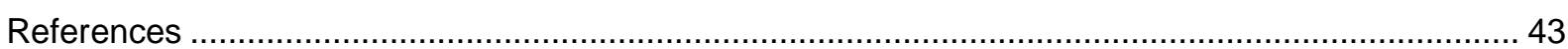

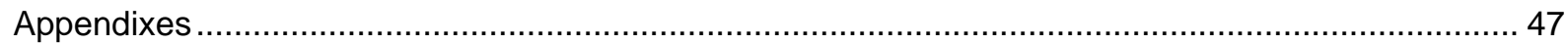




\section{INTRODUCTION}

The empirical debate about the causes of earnings inequalities was reopened at the end of the 1980s by an article by Krueger and Summers (1988). The authors highlighted the fact that the structure of wages in the US was not compatible with the competitive framework, according to which wage differentials in equilibrium are explained either through differences in the quality of the labour force - measured in terms of productive capacity - or by so-called compensating differences. In other words, they showed that wage disparities persisted between agents with identical observed individual characteristics and working conditions, employed in different sectors. Since then, similar results have been obtained for many industrialised countries (Araï et al., 1996; Ferro-Luzzi, 1994; Hartog et al., 1997, 2000; Lucifora, 1993; Vaïniomaki and Laaksonen, 1995). Accordingly, the existence of sectoral effects on workers' wages has become an accepted fact in the economic literature. Yet, the role of unmeasured abilities in explaining the inter-industry wage differentials is still unsettled (Abowd et al., 1999; Benito, 2000; Bjorklund et al., 2004; Carruth et al., 2004, Gibbons and Katz, 1992; Goux and Maurin, 1999, Martins, 2004). Moreover, while studies on industry wage premia offer some evidence against the perfectly competitive model, they hardly allow to discriminate among alternative models supporting the existence of an effect of the employer's characteristics on wages (Benito, 2000; Krueger and Summers, 1988; Lindbeck and Snower, 1990; Thaler, 1989; Walsh, 1999). In particular, little is known on the contribution of rent-sharing to the observed industry wage differentials.

The present paper adds to this literature by examining the structure, stability and possible sources of industry wage differentials in the Belgian private sector over the period 1995-2002. The existence of inter-industry wage differentials in Belgium, for both male and female workers, has been recently highlighted by Rycx (2002) and Rycx and Tojerow (2002). Using cross-sectional data for 1995, the latter show that their structure is comparable with that observed in the other industrialised countries and that they result in part from the characteristics of the employers in each sector. Moreover, findings support the hypothesis of a negative relation between the dispersion of inter-industry wage differentials and the degree of corporatism of the industrialised countries. The role of unions in bringing about these interindustry wage differentials has been investigated by Rycx (2003). His findings, based on micro-data for 1995, suggest that: i) sectors offering high/low wages are similar for workers covered by different bargaining regimes, and ii) the dispersion of inter-industry wage 
differentials is higher when wages are collectively renegotiated at the firm level. Yet, many uncertainties remain about the size, evolution and appropriate theoretical interpretation of the industry wage differentials in Belgium. This paper aims to partially fill this gap by addressing the following questions:

i) Are sectoral differences in pay a temporary phenomenon or do they persist over time?

ii) Do they derive from sectoral differences in the unobserved quality of the labour force?

iii) To what extent are they shaped by the sectors' 'ability to pay', i.e. profits?

iv) What is the contribution of rent-sharing - i.e. the elasticity between wages and profits at the firm level - to the observed industry wage differentials?

To address these questions, we rely on a unique matched employer-employee data set. This data set derives from the combination of the Structure of Earnings Survey and the Structure of Business Survey for the years 1995, 1999 and 2002. The former contains detailed information on firm characteristics (e.g. sector of activity, size of the firm, and level of wage bargaining) and on individual workers (e.g. gross hourly wages, bonuses, age, education, sex, and occupation). The latter provides firm- and sector-level information on financial variables (e.g. gross operating surplus, value added, and value of production).

The remainder of this paper is organised as follows. In the next section a brief review of the literature on the magnitude and sources of industry wage differentials is presented. Section 3 describes the data used in the paper and displays summary statistics. Section 4 examines the size, dispersion and stability of industry wage differentials in the Belgian private sector over the period 1995-2002. The unobserved quality explanation of industry wage differentials is tested in section 5. Section 6 analyses whether industry wage differentials result from sectoral differences in 'ability to pay', i.e. profits. The firm-level elasticity between wages and profits and the contribution of rent-sharing to the observed industry wage differentials are examined in section 7 . The last section concludes. 


\section{THEORETICAL AND EMPIRICAL BACKGROUND}

According to the standard Walrasian (competitive) model of the labour market, where the equilibrium wage is determined through marginal productivity, two agents with identical productive characteristics necessarily receive the same wages. However, so-called compensating differences may occur between similar individuals placed in different working conditions. Indeed, the disutility undergone by one individual following the performance of a task in an unfavourable situation may lead to wage compensation. This simple description of the wage determination process has been challenged by the pioneering observations of Slichter (1950) and more recently by Dickens and Katz (1987), Krueger and Summers (1987, 1988), and Katz and Summers (1989). These authors demonstrated that pay differentials existed in the US between workers with the same observable individual characteristics and working conditions employed in different sectors. In recent years, comparable results have been obtained for a large number of countries (Araï et al., 1996; Ferro-Luzzi, 1994; Hartog et al., 1997; Lucifora, 1993; Vainiomäki and Laaksonen, 1995). Moreover, it has been shown that the structure of the industry wage differentials is quite stable over time (Helwege, 1992), and similar across the industrialised countries (Zanchi, 1992). A number of studies, except that of Bjorklund et al. (2004), suggest in addition that sectoral effects are significantly weaker in strongly corporatist countries, regardless of the period studied (Edin and Zetterberg, 1992; Gannon et al., 2005; Hartog et al. 2000; Kahn, 1998; Teulings and Hartog, 1998; Zweimüller and Barth, 1994). Teulings and Hartog (1998), for example, report that from the most to the least corporatist country the dispersion in industry wage premia increases roughly at a ratio of 1:4. The concept of corporatism, borrowed from political science, resembles the level of centralisation of collective bargaining as well as the degree of co-ordination between the social partners. However, as this concept has not been defined in one single way, there are differences in opinion as to the relative position of the industrialised countries on the scale of corporatism (OECD, 1997, 2004). The Scandinavian countries and Austria are nevertheless always in the category of strongly corporatist countries, whereas the US and Canada are invariably at the bottom of the ranking. Depending on the authors, Belgium is ranked intermediate or high on the scale of corporatism.

Overall, the existence of sectoral wage premia cast increasingly doubt on the assumption of a perfectly competitive labour market. Indeed, they suggest that individual wages are not solely determined by personal productive characteristics and task descriptions but also by the 
features of the employers in each sector. Nevertheless, many uncertainties remain. One of these derives from the fact that the unobserved quality of the labour force might not be randomly distributed among industries. In other words, high-paying industries might simply be those in which the unmeasured labour quality is the highest. Using the 1984 and 1986 Displaced Workers Surveys, Gibbons and Katz (1992) show for the US that the magnitude of the industry wage differentials is almost undiminished when estimating wage equations in first differences rather than in levels. Their findings thus indicate that the workers' sectoral affiliation does matter. The unobserved quality explanation has also been tested by Martins (2004). Applying quantile regressions to a Portuguese matched employer-employee data set from 1995, the author rejects the hypothesis that high-wage industries draw disproportionately more on high-ability workers. Therefore, he suggests that non-competitive forces may play an important role in the wage determination process. In contrast, findings of Goux and Maurin (1999) and Abowd et al. (1999) show that individual fixed effects explain a large fraction of the estimated inter-industry wage differentials in France. A similar result has been found by Benito (2000) using individual-level data from the British Household Panel Survey for 1991 and 1994, respectively. All in all, there is no consensus regarding to exact scale of the industry wage premia. Moreover, while studies on industry wage premia offer some evidence against the perfectly competitive model, they hardly allow to discriminate among alternative models supporting the existence of an effect of the employer's characteristics on wages (Benito, 2000; Krueger and Summers, 1988; Lindbeck and Snower, 1990; Thaler, 1989; Walsh, 1999).

Prima facie, wage disparities observed between sectors militate in favour of the efficiency wage theory. Indeed, the latter shows that if the incentive conditions for effort vary between sectors, then two individuals with identical individuals characteristics, placed in the same working conditions are likely to earn different wages. For instance, according to the effort version of the efficiency wage theory, big companies would find it in their interests to offer relatively higher wages to their employees because they face higher costs in order to monitor the effort of the latter. However, this theory does not make it clear why the scale of the interindustry wage differentials varies between countries and appears to be more compressed in corporatist countries. The constraints encouraging companies to pay efficient wages, i.e. wages above the competitive level, actually seem to be similar among the industrialised countries. Therefore, some authors (Hartog et al., 1997) believe that the justification put forward by Holmlund and Zetterberg (1991), based upon the rent-sharing theory, is more 
compelling. The latter showed that the influence of the sectoral conditions (variations in prices and productivity) on wages is strong in the US, moderate in Germany and low in the Scandinavian countries. The elasticity between the sectoral environment and wages would thus be more pronounced in the non-corporatist countries. To put it another way, the determination of wages would depend more on the general macro-economic conditions in the corporatist countries. This result might be explained by the fact that the explicit or implicit coordination of the wage bargaining in the corporatist countries restricts the insider power of the workers, in other words their ability to capture part of the sectoral rents. In addition, it is argued that the policy of 'wage solidarity' pursued by unions in most of the corporatist countries reinforces this phenomenon. For instance, Vainiomäki and Laaksonen (1995: 172) emphasise that 'the difference (in the dispersion of inter-industry wage differentials) between Sweden and Finland (may derive from) the less successful implementation of solidarity wage policy and more flexibility in industry level agreements in Finland'. In sum, this strand of the literature suggests that rent-sharing is partly responsible for the observed sectoral wage premia and for their apparently higher dispersion in non-corporatist countries.

However, a more convincing test of the rent-sharing theory is provided by studies focussing directly on the wage-profit elasticity using firm level data (Abowd and Lemieux, 1993; Araï, 2003; Blanchflower et al., 1996; Christophides and Oswald, 1992; Fakhfakh and FitzRoy, 2004; Goos and Konings, 2001; Gürtzgen, 2005; Hildreth and Oswald, 1997; Margolis and Salvanes, 2001; Rycx and Tojerow, 2004; Teal, 1996; Van Reenen, 1996). The theoretical approach in these studies is a bargaining framework (often the right-to-manage or the efficient bargaining model) in which insiders (not necessarily a union) bargain over wages and eventually employment. Findings from this literature show that profitable firms pay higher wages even when controlling for human capital characteristics and firm fixed effects. Nevertheless, it is still unclear whether the magnitude of the pay-profit elasticity is larger in countries with little centralisation or corporatism. Moreover, the assessment of how rentsharing contributes to the industry wage differentials is yet to be performed.

\section{DESCRIPTION OF THE DATA}

The present study is based upon the Structure of Earnings Survey (SES) and the Structure of Business Survey (SBS) carried out by Statistics Belgium. The SES, currently available for the years 1995, 1999 and 2002, is a large matched worker-firm data set. It covers the Belgian 
establishments employing at least ten workers whose economic activities fall within section $\mathrm{C}$ to $\mathrm{K}$ of the Nace Rev. 1 nomenclature. It thus encompasses the following sectors: mining and quarrying (C), manufacturing (D), electricity and water supply (E), construction (F), wholesale and retail trade; repair of motor vehicles, motorcycles and personal and household goods $(\mathrm{G})$, hotels and restaurants $(\mathrm{H})$, transport, storage and communication (I), financial intermediation $(\mathrm{J})$, real estate, renting and business activities $(\mathrm{K})$. The survey contains a wealth of information, provided by the management of the establishments, both on establishment-level characteristics (e.g. sector of activity, region, size of the establishment, and level of wage bargaining) and individual workers (e.g. education, potential experience, seniority, number of working hours paid, gender, occupation, and gross hourly wages including and excluding annual bonuses ${ }^{1}$ ). Gross hourly wages - excluding bonuses ${ }^{2}-$ are calculated by dividing total gross earnings (including earnings for overtime hours and premiums for shift work, night work and/or weekend work) in the reference period (October) by the corresponding number of total paid hours (including paid overtime hours). In contrast, gross hourly wages - including bonuses - are obtained by adding to the gross hourly wages (exluding bonuses) the annual bonuses divided by: i) the number of month to which the bonuses correspond and ii) the number of total paid hours in the reference period, respectively. Potential experience is not directly reported in the SES. It is computed as follows: age $-6-$ years of education - seniority. It measures the number of years of experience potentially accumulated on the labour market before the last job. ${ }^{3}$

The 1995 wave of the SES was conducted using a representative sample of 145,107 individuals working for 6,015 establishments. Yet, the simultaneous use of data relating to wages and levels of education yield a representative sub-sample of 81,562 individuals working for 4,092 establishments. ${ }^{4}$ After the exclusion of individuals for whom one of the variables used entailed an incorrect or missing observation ${ }^{5}$, the number of individuals in the

\footnotetext{
${ }^{1}$ Information on annual bonuses is only available for 1995 and 2002.

2 Annual bonuses include irregular payments which do not occur during each pay period, such as pay for holiday, $13^{\text {th }}$ month or profit-sharing.

3 This variable should be considered with caution since it overestimates the labour market experience of individuals that have been employed part-time or had carrier breaks.

${ }^{4}$ The representative character of this sub-sample is illustrated in Demunter (2000) and Rycx (2002).

${ }^{5}$ Observations in which tenure was greater than worker's age were deleted. This reduces the sample size by $1.4 \%$. Records with missing values for the level of wage bargaining or the variable showing whether the
} 
sample falls by approximately $2.1 \%$ to 79,835 units. Finally, the exclusive selection of establishments that are at least 50 per cent owned by the private sector brings the definitive sample to 67,023 individuals. This selection is justified by the fact that the wages are determined in very different ways in the public and private sectors. Taking into account establishments where economic and financial control is primarily in public hands would in fact be liable to skew our results. A similar filtering process has been applied to the 1999 and 2002 waves of the SES. The initial surveys include respectively 124,272 and 108,677 observations. However, the exclusion of incorrect or missing values and the selection of establishment that are at least 50 per cent owned by the private sector bring the definitive samples respectively to 111,297 and 102,594 individuals.

The SES provides no financial information. However, one of the objectives of this paper is to examine the relationship between wages and profits, both at the sectoral and firm level. Indeed, on the one hand, we want to analyse whether industry wage differentials result from sectoral differences in 'ability to pay', i.e. profits (section 6). On the other, we wish to estimate the elasticity between wages and profits at the firm level and measure the contribution of rent-sharing to the observed industry wage differentials (section 7). To attain these goals the SES has been merged with the Structure of Business Survey (SBS), at the sectoral level in section 6 and the firm level in section 7. The SBS, conducted by Statistics Belgium, provides information on financial variables such as sales, value added, value of production, gross operating surplus and value of acquired goods and services. It is available at the sectoral level (Nace three-digit nomenclature) in 1995, 1999 and 2002. At the firm level, it could only be obtained for the year 1995. The coverage of the SBS differs from the SES in that it does not include the financial sector (Nace J). Moreover, when it is merged to the SES at the firm level (section 7), many observations are lost. The final sample, combining the SES and the SBS at the firm level in 1995, covers 34,972 individuals working for 1,501 firms. It is representative of all firms employing at least 20 workers within sections $\mathrm{C}$ to $\mathrm{K}$ of the Nace Rev.1 nomenclature, with the exception of the financial sector.

individual supervises the work of his co-workers were suppressed. However, it can be shown that results presented in this article would not have been significantly different if these observations had been taken into account. 
Table 1: Means (Standard Deviations) of Selected Variables

\begin{tabular}{|c|c|c|c|}
\hline Variables / Data set: & $\mathrm{SES}^{\mathrm{a}} 1995$ & SES 1999 & SES 2002 \\
\hline Gross hourly wage, excluding bonuses (in EUR) $^{b}$ & $\begin{array}{c}12.32 \\
(5.7)\end{array}$ & $\begin{array}{c}13.12 \\
(6.6)\end{array}$ & $\begin{array}{c}13.74 \\
(6.5)\end{array}$ \\
\hline \multicolumn{4}{|l|}{ Education: } \\
\hline Primary or no degree & 9.7 & 8.5 & 8.1 \\
\hline Lower secondary & 24.3 & 29.6 & 28.0 \\
\hline General upper secondary & 18.4 & 21.0 & 19.2 \\
\hline Technical/Artistic/Prof. upper secondary & 24.9 & 17.4 & 19.7 \\
\hline Higher non-university short type, higher artistic training & 13.9 & 14.8 & 15.3 \\
\hline University and non-university higher education, long type & 8.4 & 8.3 & 8.9 \\
\hline Post-graduate & 0.5 & 0.5 & 0.6 \\
\hline Prior potential experience $(\text { years })^{c}$ & $\begin{array}{c}9.5 \\
(8.5)\end{array}$ & $\begin{array}{l}10.9 \\
(8.8)\end{array}$ & $\begin{array}{l}11.5 \\
(9.7)\end{array}$ \\
\hline Seniority in the current company (years) & $\begin{array}{c}9.9 \\
(9.0)\end{array}$ & $\begin{array}{c}8.9 \\
(9.3)\end{array}$ & $\begin{array}{c}8.5 \\
(9.1)\end{array}$ \\
\hline Hours $^{\mathrm{d}}$ & $\begin{array}{l}160.5 \\
(26.5)\end{array}$ & $\begin{array}{l}147.7 \\
(40.6)\end{array}$ & $\begin{array}{l}153.8 \\
(41.4)\end{array}$ \\
\hline Female (yes) & 31.4 & 30.3 & 32.0 \\
\hline \multicolumn{4}{|l|}{ Type of contract: } \\
\hline Unlimited-term employment contract & 97.0 & 95.0 & 95.7 \\
\hline Limited-term employment contract & 2.4 & 3.7 & 3.4 \\
\hline Apprentice/Trainee contact & 0.1 & 0.2 & 0.2 \\
\hline Other & 0.4 & 1.2 & 0.7 \\
\hline Size of the establishment (number of workers) & $\begin{array}{c}501.8 \\
(1,133.8)\end{array}$ & $\begin{array}{c}705.3 \\
(1,857.0)\end{array}$ & $\begin{array}{c}651.6 \\
(1,661.5)\end{array}$ \\
\hline \multicolumn{4}{|l|}{ Region where the establishment is located: } \\
\hline Brussels & 17.6 & 22.7 & 16.4 \\
\hline Wallonia & 19.4 & 17.9 & 21.5 \\
\hline Flanders & 63.0 & 59.4 & 62.1 \\
\hline \multicolumn{4}{|l|}{ Level of wage bargaining: } \\
\hline $\mathrm{CA}^{\mathrm{e}}$ only at the national and/or sectoral level & 51.7 & 73.5 & 79.2 \\
\hline CA at the company level & 39.4 & 26.5 & 19.9 \\
\hline Other & 9.0 & 0.0 & 1.2 \\
\hline Number of observations & 67,023 & 108,677 & 102,594 \\
\hline
\end{tabular}

Table 1 depicts the means and standard deviations of selected variables in the 1995, 1999 and 2002 waves of the SES. ${ }^{6}$ We note that, on average, the gross hourly wage (excluding bonuses) amounts to 13 EUR, three-quarters of the workers have at most a degree from the upper secondary school, workers have 10 years of potential experience and 9 years of seniority, the proportion of women is slightly less than one-third, and more than 95 per cent of the workers are employed on an unlimited-term employment contract. Also noteworthy is that the number of hours paid per month (including overtime) has been decreasing from 161 in 1995 to 154 in 2002. Moreover, we find that the average establishment size has been increasing over time

\footnotetext{
${ }^{6}$ For a more detailed description see Appendix 1. Descriptive statistics relative to the merged SES-SBS sample at the firm level in 1995 are reported in Appendix 2.
} 
(652 in 2002 vs. 502 in 1995) and that the majority of the workforce is employed in Flanders (62 per cent in 2002). Finally, let us notice that the proportion of workers whose wages are collectively renegotiated at the company level has been decreasing from approximately 39 to 20 per cent between 1995 and 2002. The majority of workers have their wages thus solely determined through national and/or sectoral collective agreements.

\section{Figure 1: Gross Hourly Wages (Including Bonuses) and Employment Shares for Nace Two-Digit Industries, 2002}

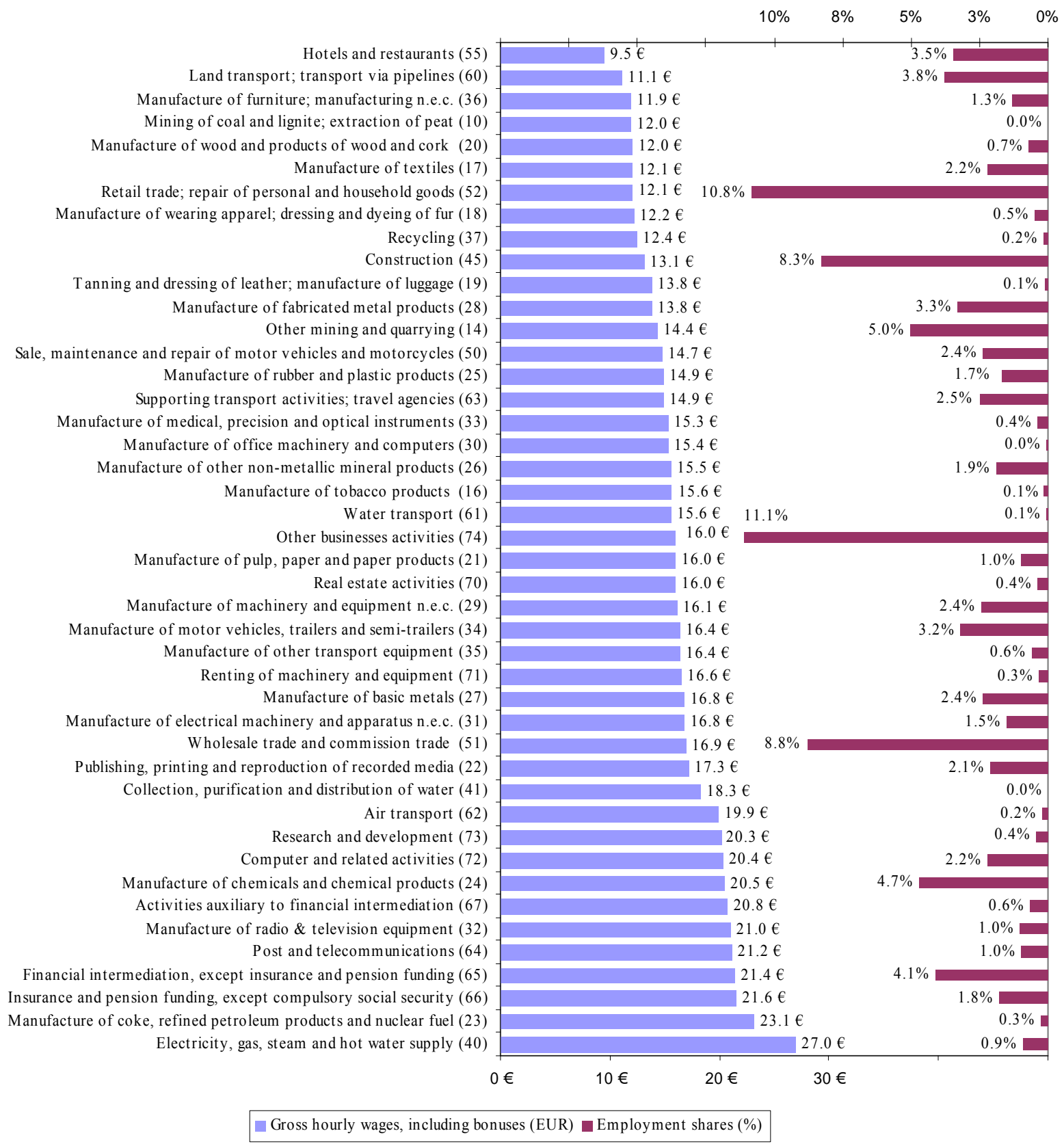

Source: Structure of Earnings Survey, 2002. 
Figure 1 shows the distribution of employment across sectors as well as the mean gross hourly wage (including bonuses) in each industry for the year $2002 .^{7}$ Findings indicate that more than 30 per cent of the workers are concentrated in the three following sectors: i) other business activities (11.1 per cent), ii) retail trade; repair of personal and household goods (10.8 per cent), and iii) wholesale trade and commission trade ( 8.8 per cent). A large fraction of the workforce is also employed in the other mining and quarrying sector ( 5 per cent), the manufacture of chemicals and chemical products sector ( 4.7 per cent), and the financial intermediation sector (4.1 per cent).

Figure 1 reveals in addition that mean gross hourly wages (including bonuses) fluctuate considerable across sectors. The best paying industry is the electricity, gas, steam and hot water supply sector. The average worker there earns 27 EUR per hour. This sector is followed by the manufacture of coke, refined petroleum and nuclear fuel industries (23.1 EUR), the insurance and pension funding sector (21.6 EUR), the financial intermediation sector (21.4 EUR), and the post and telecommunications sector (21.2 EUR). The hotels and restaurant sector is at the very bottom of the wage scale. The average worker's hourly wage here is 9.5 EUR, almost 300 per cent less than that of the average worker in the best paying industry. At the bottom of the scale, we likewise find land transport and transport via pipelines (11.1 EUR), manufacture of furniture (11.9 EUR), manufacture of wood and products of wood and cork (12 EUR), manufacture of textiles (12.1 EUR), and retail trade, repair of personal and household goods (12.1 EUR).

Where do these substantial gross wage differentials come from ? Can they be accounted for solely by the sectoral heterogeneity in (observed and unobserved) workers productive characteristics and working conditions, or do they also derive from the specific features of the employers in each sector, e.g. profits ? These questions, among others, are analysed in the remainder of this paper.

\footnotetext{
${ }^{7}$ The same figure for the year 1995 is reported in Appendix 3.
} 


\section{MAgnitude, DisPersion AND StabiLITy OF INDUSTRY WAge DifFerentials}

\subsection{Methodology}

The methodology that has been adopted to estimate the magnitude and dispersion of interindustry wage differentials in the Belgian private sector over the period 1995-2002 is consistent with that of Krueger and Summers (1988). However, the standard errors of the industry wage differentials have been corrected according to Zanchi (1998).

Overall, this strategy rests upon the estimation, for each period, of the following Mincer-type (1974) wage equation:

$$
\ln w_{i}=\alpha+\sum_{j=1}^{J} \beta_{j} X_{j, i}+\sum_{k=1}^{K} \psi_{k} Y_{k, i}+\sum_{l=1}^{L} \delta_{l} Z_{l, i}+\varepsilon_{i}
$$

where $w_{i}$ represents the gross hourly wage of the individual $i$ (for $i=1, \ldots, \mathrm{N}$ ); $X$ is the vector of the individual characteristics of the workers and their working conditions (6 dummy variables showing the highest completed level of education; prior potential experience, its square and its cube; seniority within the current company and its square; sex; 22 occupational dummies; number of hours paid; an indicator showing whether the individual is paid a bonus for shift work, night-time and/or weekend work; a dummy for extra paid hours; 3 dummies for the type of contract; and a dichotomic variable indicating whether the individual supervises other workers ${ }^{8}$ ); $Y$ comprises dummy variables relating to the sectoral affiliation of the individuals (nomenclature available both at the Nace two- and three-digit level) ; $Z$ contains employer's characteristics ( 2 regional dummies indicating where the establishment is located; the size of the establishment; and 2 dummies for the level of wage bargaining); $\alpha$ is the intercept; $\beta, \psi$ and $\delta$ are the parameters to be estimated and $\varepsilon_{\mathrm{i}}$ is an error term (see Appendix 1 for a detailed description of the variables).

\footnotetext{
${ }^{8}$ This variable is only available in the 1995 wave of the SES.
} 
Technically, the computation of inter-industry wage differentials first of all involves calculating the employment-weighted average wage differential of all the sectors compared to the reference:

$$
\pi=\sum_{k=1}^{K} \bar{p}_{k} \hat{\psi}_{k} \quad(\text { for } k=1, \ldots, K)
$$

where $\hat{\psi}_{k}$ is the estimated sector coefficient and $\bar{p}_{k}=\frac{1}{N} \sum_{i=1}^{N} p_{k, i} \quad($ for $k=1, \ldots, K+1)$ is the sectoral employment share;

and then applying the formulae below:

$$
\left\{\begin{array}{l}
d_{k}=\hat{\psi}_{k}-\pi \quad(\text { for } k=1, \ldots, K) \\
d_{K+1}=-\pi
\end{array}\right.
$$

In order to test accurately hypotheses about the inter-industry wage differentials, the standard errors of the original industry coefficients have been adjusted according to Zanchi (1998). To put it differently, we first transformed the variance-covariance matrix found when estimating equation (1) by ordinary least squares (OLS) as follows:

$$
\operatorname{var}-\operatorname{cov}\left(\hat{\psi}^{*}\right)=\left(H-e s^{\prime}\right) \operatorname{var}-\operatorname{cov}(\hat{\psi})\left(H-e s^{\prime}\right)^{\prime}
$$

where $H$ is a $((K+1) \mathrm{x} K)$ matrix constructed as the stack of a $(K \mathrm{x} K)$ identity matrix and a $(1 \mathrm{x} K)$ row of zeros, $e$ is a $((K+1) \times 1)$ vector of ones, $s$ represents the employment shares of the $K$ first industries, and $\operatorname{var}-\operatorname{cov}(\hat{\psi})$ is the original variance-covariance matrix of the industry dummy coefficients. Next, the correct estimates of the standard errors of the industry wage differentials were obtained by taking the square roots of the diagonal elements of this transformed variance-covariance matrix.

According to Zanchi (1998), the variability in industry wage differentials has been measured by the standard deviation of the industry wage premia, adjusted for least squares sampling error and weighted by sectoral employment shares. This summary statistic, further referred in 
the text as WASD (i.e. weighted adjusted standard deviation), corresponds to the following expression:

$$
W A S D\left(d_{k}\right)=\sqrt{\sum_{k=1}^{K+1} \bar{p}_{k}\left(d_{k}-\frac{\sum_{k=1}^{K+1} d_{k}}{K+1}\right)^{2}-\frac{\sum_{k=1}^{K+1} \operatorname{var}\left(\hat{\psi}_{k}^{*}\right)}{K+1}+\frac{\sum_{k=1}^{K+1} \sum_{l=1}^{K+1} \operatorname{var}-\operatorname{cov}\left(\hat{\psi}_{k}^{*}, \hat{\psi}_{l}^{*}\right)}{(K+1)^{2}}(5)}
$$

The dispersion in industry wage premia has also been assessed by the wage range in moving from the lowest- to the highest-paying industry.

\subsection{Wage Regressions}

Before embarking upon the analysis of the effects of workers' sectoral affiliation on wages, we briefly discuss the results from equation (1) that has been estimated for each period by OLS with White (1980) heteroscedasticity-consistent standard errors. ${ }^{9}$

Table 2: Wage Regressions

(Dependent variable: Ln of individual gross hourly wages excluding annual bonuses)

\begin{tabular}{lccc}
\hline Explanatory variables / Period : & 1995 & 1999 & 2002 \\
\hline Intercept & $1.825^{* *}$ & $2.043^{* *}$ & $2.181^{* *}$ \\
& $(0.025)$ & $(0.017)$ & $(0.018)$ \\
Education: & & & \\
$\quad$ Primary or no degree & & Reference \\
Lower secondary & $0.053^{* *}$ & $0.045^{* *}$ & $0.034^{* *}$ \\
General upper secondary & $(0.004)$ & $(0.003)$ & $(0.004)$ \\
& $0.140^{* *}$ & $0.105^{* *}$ & $0.100^{* *}$ \\
Technical/Artistic/Prof. upper secondary & $(0.005)$ & $(0.004)$ & $(0.004)$ \\
& $0.128^{* *}$ & $0.118^{* *}$ & $0.111^{* *}$ \\
Higher non-university short type, higher artistic training & $(0.004)$ & $(0.004)$ & $(0.004)$ \\
& $0.221^{* *}$ & $0.195^{* *}$ & $0.192^{* *}$ \\
University and non-univ. higher education, long type & $(0.006)$ & $(0.005)$ & $(0.005)$ \\
Post-graduate & $0.383^{* *}$ & $0.355^{* *}$ & $0.332^{* *}$ \\
Prior potential experience: & $(0.007)$ & $(0.007)$ & $(0.007)$ \\
Simple & $0.510^{* *}$ & $0.525^{* *}$ & $0.478^{* *}$ \\
& $(0.019)$ & $(0.021)$ & $(0.021)$
\end{tabular}

\footnotetext{
${ }^{9}$ Findings discussed in this sub-section are based on a wage equation where the dependent variable is the individual gross hourly wage excluding annual bonuses. Results based on gross hourly wages including annual bonuses are reported in the Appendix 4. The latter are quite similar to the former although the magnitude of some regression coefficients may differ to some extent.
} 
Squared $/ 10^{2}$

$\begin{array}{ccc}-0.036 * * & -0.066 * * & -0.044 * * \\ (0.000) & (0.005) & (0.003) \\ 0.022 * & 0.075 * * & 0.032 * * \\ (0.010) & (0.008) & (0.006) \\ & & \\ 0.017 * * & 0.016 * * & 0.017 * * \\ (0.000) & (0.000) & (0.000) \\ -0.017 * * & -0.017 * * & -0.020 * * \\ (0.001) & (0.001) & (0.001)\end{array}$

Sex:

Cubed $/ 10^{4}$

Reference

Male

Female

$-0.116^{* *} \quad-0.128^{* *}$

$-0.121 * *$

$(0.003)$

(0.002)

(0.002)

Supervises the work of his or her co-workers:

Yes

$0.110 * *$

(0.004)

Hours:

Ln of the number of hours paid, including overtime paid

$\begin{array}{ccc}-0.000 & -0.008 * & -0.023 * * \\ (0.005) & (0.003) & (0.003) \\ & & \\ 0.057 * * & 0.031 * * & 0.046 * * \\ (0.004) & (0.003) & (0.003) \\ & & \\ 0.024 * * & 0.030 * * & 0.035 * * \\ (0.005) & (0.004) & (0.005)\end{array}$

Contract:

Unlimited-term employment contract

Limited-term employment contract

Reference

$-0.026 * * \quad-0.086 * *$

$-0.064 * *$

Apprentice/Trainee contract

$(0.007)$

$-0.636^{* *}$

$-0.086^{*}$

$(0.007)$

$(0.093)$

$-0.831 * *$

$-0.296 * *$

Other employment contract

$-0.024$

(0.024)

$(0.072)$

(0.026)

Yes

$-0.039 * *$

$-0.032 * *$

Occupation (22 dummies)

Sector of activity (respectively 174, 171 and 179 dummies)

Region where the establishment is located:

Yes

Brussels

Reference

$-0.036 * * \quad-0.043 * * \quad-0.022 * *$

$\begin{array}{lll}(0.004) & (0.003) \quad(0.003)\end{array}$

Flanders

$-0.037 * *$

$-0.010 * *$

0.003

(0.003)

$(0.003)$

(0.003)

Size of the establishment:

$\mathrm{Ln}$ of the number of workers

$0.029 * * \quad 0.028 * * \quad 0.028 * *$

$\begin{array}{lll}(0.001) & (0.001) \quad(0.001)\end{array}$

Level of collective wage agreement:

Only at the national and/or sectoral level

Company level

Reference

$0.022 * * \quad 0.016^{* *} \quad 0.030 * *$

Other type of agreement

$\begin{array}{lll}(0.003) & (0.002) \quad(0.003)\end{array}$

$\begin{array}{lll}-0.016^{* *} & / & -0.011\end{array}$

$\begin{array}{ccc}(0.004) & & (0.007) \\ 0.713 & 0.659 & 0.623\end{array}$

\begin{tabular}{|c|c|c|c|}
\hline Adjusted $\mathrm{R}^{2}$ & 0.713 & 0.659 & 0.623 \\
\hline F-test & $535.5 * *$ & $479.5 * *$ & $405.0 * *$ \\
\hline
\end{tabular}

$\begin{array}{lrrr}\text { Number of observations } & 67,023 & 108,677 & 102,594\end{array}$

Notes: White (1980) heteroscedasticity-consistent standard errors are reported between brackets. Results are based on equation (1), estimated on the basis of the 1995, 1999 and 2002 Structure of Earnings Surveys.

$* * / * /{ }^{\circ}$ : coefficient significant at the 1,5 and 10 per cent level, respectively. 
Results in Table 2 show, in line with human capital theory, that the level of education exercises a substantial positive influence upon wages. However, the return on education appears to have significantly decreased between 1995 and 2002. Indeed, compared to someone with a primary education qualification (or no degree), the wage differential has dropped from 15 to 10 per cent ${ }^{10}$ for someone with a general upper secondary education, from 25 to 21 per cent for someone qualified on a short non-university higher education course, from 47 to 39 per cent for someone with a long non-university or university higher education, and from 67 to 61 per cent for an individual who has obtained a postgraduate degree. ${ }^{11}$

Not surprisingly, we also see a concave relation between the wages and the general potential experience of a worker on the labour market. ${ }^{12}$ Initially, the return on an additional year of experience stands at between 1.6 and 1.9 per cent, depending on the year under investigation. However, it decreases progressively and becomes negative after around 30 years of experience. All other things being equal, an individual with 29 years of experience obtains a wage differential of approximately 20 per cent compared to the reference workers whose gross hourly wage has increased from 6.2 to 8.9 Euros between 1995 and 2002. The hypothesis of a bell-shaped relationship between wages and experience rests upon the idea that the investment in human capital (specific training and accumulation by work) diminishes over time and that the stock of human capital suffers from some degree of obsolescence. The growing share of the relationship between wages and experience is explained essentially by the evolution of individual productivity and partly by scale increases.

The relationship between wages and seniority in the company is also in the form of a bell. However, the return on seniority decreases markedly less quickly than that on experience. This difference can be explained through the almost automatic increase in wages as a function of years of seniority (essentially for white-collar workers) and through the progression in the earnings classification (i.e. promotion by seniority). It also illustrates the fact that companies offer more rewards for the human capital specific to their working environment. Finally, these

\footnotetext{
${ }^{10}$ Technically, this figure is obtained by taking the antilog (to base e) of the estimated dummy coefficient from which 1 is subtracted (x 100). For more details see Gujarati (1995: 525).

${ }^{11}$ However, the decrease in the return on education for postgraduates is not statistically significant $(\mathrm{t}=1.13)$.

${ }^{12}$ The introduction of potential experience in the form of an order three polynomial rests upon the results of Murphy and Welch (1990).
} 
results support the 'turnover' version of the efficiency wage theory (Stiglitz, 1974) according to which companies grant a bonus to workers who are faithful to them.

The dummy variable relating to gender suggests that all other things being equal, women are paid wages which are between 11 and 12 per cent lower than those of men. This result is in line with the growing literature on the gender wage gap in Belgium. Jepsen (2001) shows, for instance, on the basis of the 1994 and 1995 Panel Study of Belgian Households (PSBH), that the sex wage gap between full-time workers stands at around 15 per cent and that only a small part of it can be explained by gender differences in endowments. In contrast, using the 1995 Structure of Earnings Survey (SES), Plasman et al. (2001) suggest that the wage gap between (all) men and women working in the Belgian private sector reaches almost 22 per cent and that half of it is attributable to gender differences in working conditions, individual and firm characteristics. Using the PSBH, Konings (2005) shows in addition that the gender wage gap in the Belgian economy has been stable over the period 1998 - 2002 and that a substantial part of it can be attributed to discrimination. Findings reported in Table 2 corroborate this conclusion. Indeed, they show the existence of a persistent gender wage gap even after controlling for individual and firm characteristics. To put it differently, they reject the hypothesis of a 'natural' trend towards pay equality.

We likewise observe a wage differential of 11.6 per cent in favour of individuals supervising the work of their co-workers. This result stems from the fact that all other things being equal, these individuals have a higher degree of responsibility within the company. It also backs up the 'effort' version of the efficiency wage theory (Shapiro and Stiglitz, 1984). According to this theory, it is optimal for a company to offer a bonus to employees whose effort it is not able to monitor constantly, and to carry out intermittent checks with respect to them, including dismissal in the event of insufficient effort. To sum up, these results suggest the existence of a positive relationship between the wage of an individual and his degree of autonomy at work. Notice that such a relationship has also been observed in other countries (Araï, 1994; Groshen and Krueger, 1990). 
Table 2 reveals, in addition, that the number of hours has a negative but rather limited influence on the gross hourly wage. ${ }^{13}$ This result is in line with earlier work of Jepsen (2001) and Jepsen et al. (2005). Both studies examine the wage penalty associated with part-time employment in Belgium. Using respectively the PSBH and the SES, the authors find no sign of a "within industry and occupational group" wage penalty against part-timers. However, they report a substantial "market-wide" wage gap. These findings suggest that, although discrimination legislation seems to be working, part-timers are segregated both at the occupational and sectoral level.

The fact of putting in extra paid hours or being paid a bonus for non-typical working hours (shift work, night work and/or weekend work) leads to an increase in hourly wages of around 3 and 5 per cent respectively compared to the reference category. Also noteworthy is that the wage penalty of those employed on a limited-term employment contract has increased from 2.6 per cent in 1995 to 6.2 per cent in 2002 with respect to their opposite numbers with an unlimited-term contract. The existence of a wage penalty against workers with a finite-term contract is compatible with the proposal put forward by Harris and Holmström (1982). According to this proposal, employers levy an amount on the wages of newcomers in order to pay for their uncertainty as to their productive ability. Be that as it may, the reason why the wage penalty against workers on a fixed-term contract has increased over time remains unclear.

As regards establishment characteristics, we find that all other things being equal wages are significantly lower in Wallonia and Flanders (except in 2002) than in Brussels. Yet, the

\footnotetext{
${ }^{13}$ The regression coefficients relative to the number of hours and over-time hours should be interpreted with caution. This is due to a potential endogeneity bias. Indeed, even if employees can not always freely choose their working hours, the assumption of exogenous hours is too restrictive. To put it differently, the labour supply decision might depend upon the potential market wage rate. An easy way to account for this potential bias is to use instrumental variables representing the expected working hours of each employee. Following Wolf (2002), it is extremely difficult to find appropriate instruments. Nonetheless, it has been conventional to use variables describing the household context, such as the number of small children, the marital status and the other household income. Unfortunately, these instruments are not reported in the SES. This is why controlling for the endogeneity of working hours appears to be a very difficult task. However, this should not be a major limitation for our purpose, i.e. examining inter-industry wage differentials. Findings show indeed that the inclusion of the number of working hours and a dummy for over-time paid in the wage equation affects neither the significance nor the magnitude of the other regression coefficients.
} 
magnitude of the differential is small and decreasing over time. Results also show the existence of a significant and positive effect of the employer size on workers' wages. Indeed, they suggest that, on average, a doubling of the establishment-size increases earnings by 3 per cent. Yet, according to Lallemand et al. (2005), a significant part this establishment-size wage premium could be explained by the fact that the productivity and stability of the Belgian workforce is higher in large establishments. Finally, it is found that workers covered by a company collective agreement (CA) earn between 2 and 3 per cent more than their opposite numbers whose wages are solely covered by national and/or sectoral CAs. These results fit in with findings reported earlier by Rycx (2003) and Plasman et al. (2006).

Overall, results from our wage regressions are quite satisfactory. Indeed, a substantial part of the total variation in individual hourly wages is explained by the regression model (i.e. between 62 and 71 per cent, depending on the period considered). Moreover, most regression coefficients are significant and they have the expected sign. Be that as it may, our estimates might be slightly biased because of the fact that our sample is censored. In fact it does not contain any information on the number of unemployed people or on their characteristics. Docquier et al. (1999), Laurent (2000) and Jepsen (2001) have studied this problem in the case of Belgium. Their results obtained using the PSBH suggest that the expected level of earning is not significantly tied to the fact of having a job. The assessment of a censored sample therefore would not lead to a significant selection bias in Belgium. Although this result might derive from the low percentage of unemployed people included in their samples, it does tend to back up our estimates.

\subsection{Inter-Industry Wage Differentials}

Table 3 reports the industry wage differentials for Nace two-digit industries in 1995, 1999 and $2002 .{ }^{14}$ These differentials are estimated on the basis of equation (1) using as dependent variable the $\log$ (to base e) of individual gross hourly wages excluding annual bonuses. ${ }^{15}$

\footnotetext{
${ }^{14}$ An identical analysis was carried out at the Nace three-digit level. The results arising from this, set out in the Appendix 5, support and refine our conclusions.

${ }^{15}$ Inter-industry wage differentials estimated, both at the Nace two- and three-digit level, on the basis of a wage equation where the dependent variable includes annual bonuses are reported in Appendix 6 and 7. Taking into account annual bonuses increases the magnitude and dispersion of the industry wage differentials. However, the overall conclusion remains the same.
} 
Table 3: Inter-Industry Wage Differentials, 1995-2002

Industry (NACE two-digit) / Period:

Mining of coal and lignite; extraction of peat (10)

Other mining and quarrying (14)

Manufacture of food products and beverages (15)

Manufacture of tobacco products (16)

Manufacture of textiles (17)

Manufacture of wearing apparel; dressing and dyeing of fur (18)

Tanning and dressing of leather; manufacture of luggage,

handbags, saddlery, harness and footwear (19)

Manufacture of wood and products of wood and cork, except

furniture; manufacture of articles of straw and plaiting materials (20)

Manufacture of pulp, paper and paper products (21)

Publishing, printing and reproduction of recorded media (22)

Manufacture of coke, refined petroleum products and nuclear fuel (23)

Manufacture of chemicals and chemical products (24)

Manufacture of rubber and plastic products (25)

Manufacture of other non-metallic mineral products (26)

Manufacture of basic metals (27)

Manufacture of fabricated metal products, except machinery and equipment (28)

Manufacture of machinery and equipment n.e.c. (29)

Manufacture of office machinery and computers (30)

Manufacture of electrical machinery and apparatus n.e.c. (31)

Manufacture of radio, television and communications equipment and apparatus (32)

Manufacture of medical, precision and optical instruments, watches and clocks (33)

Manufacture of motor vehicles, trailers and semi-trailers (34)

Manufacture of other transport equipment (35)

Manufacture of furniture; manufacturing n.e.c. (36)

Recycling (37)

Electricity, gas, steam and hot water supply (40)

Collection, purification and distribution of water (41)

Construction (45)

Sale, maintenance and repair of motor vehicles and motorcycles;

$1995 \quad 1999$

1995

0.018

$(0.013)$

$-0.012^{*}$

$(0.001)$

0.019

$(0.019)$

$-0.069 * *$

$(0.006)$

$-0.109 * *$

$(0.010)$

$-0.026$

$(0.023)$

$-0.031^{* *}$

(0.006)

0.067 **

$(0.009)$

$0.095^{* *}$

(0.007)

0.193 **

$(0.015)$

$0.104^{* *}$

(0.004)

0.001

(0.006)

$0.028^{* *}$

$(0.006)$

$0.023^{* *}$

$(0.006)$

$-0.004 * *$

$(0.005)$

$-0.042 * *$

(0.004)

0.021

(0.024)

$-0.002$

$(0.007)$

$0.018^{*}$

(0.007)

0.020

$(0.013)$

$-0.036^{* *}$

$(0.005)$

$0.016^{*}$

(0.008)

$-0.076^{* *}$

(0.006)

$-0.059 * *$

$(0.014)$

0.229 **

(0.005)

/

0.000

$(0.005)$

$-0.031^{* *}$

0.004

$0.014 *$

$(0.005)$

0.031

0.003

$-0.003$

2002

$-0.157^{* *}$

$(0.022)$

-0.007 *

(0.003)

$(0.015)$

$(0.003)$

$0.054 * *$

(0.015)

$-0.038^{* *}$

$(0.005)$

$-0.124 * *$

(0.009)

$-0.045^{*}$

$(0.018)$

$-0.050 * *$

(0.006)

$0.040^{* *}$

$(0.013)$

$-0.040 * *$

$(0.005)$

$-0.107 * *$

$(0.010)$

$-0.088^{* *}$

$(0.014)$

$-0.055^{* *}$

(0.006)

$0.053^{* *} \quad 0.058^{* *}$

(0.007)

$(0.006)$

$0.051 * *$

$0.027^{*}$

(0.006)

$0.271^{* *}$

(0.012)

$(0.016)$

$0.109^{* *}$

$(0.015)$

$(0.004)$

$0.102^{* *}$

(0.004)

$(0.006)$

$0.013 * *$

$-0.027 * *$

$(0.005)$

0.066 **

$0.026^{* *}$

$(0.005)$

(0.007)

$-0.027^{* *}$

$-0.017 * *$

$(0.006)$

(0.004)

$-0.018^{* *}$

$-0.016 * *$

(0.004)

(0.004)

(0.026)

0.011 *

$(0.005)$

$-0.061 * *$

$(0.017)$

(0.006)

$-0.012^{\circ}$

$0.016^{\circ}$

$(0.009)$

(0.007)

0.072 **

$(0.009)$

$-0.008$

(0.008)

$-0.024^{* *}$

$-0.005$

(0.008)

$-0.036^{* *}$

(0.005)

$(0.005)$

$-0.020^{* *}$

(0.008)

$-0.095^{* *}$

$(0.007)$

$-0.097^{* *}$

(0.005)

$-0.079 * *$

$(0.005)$

$-0.025 *$

(0.010)

(0.010)

$0.254^{* *}$

$0.225 * *$

(0.008)

(0.009)

$0.122 *$

(0.056)

0.008* $\quad 0.016^{* *}$

(0.004)

$(0.003)$

$0.011 *$

$0.021 * *$ 
retail sale of automotive fuel (50)

Wholesale trade and commission trade, except of motor vehicles and motorcycles (51)

Retail trade, except of motor vehicles and motorcycles; repair of personal and household goods (52)

Hotels and restaurants (55)

Land transport; transport via pipelines (60)

Water transport (61)

Air transport (62)

Supporting and auxiliary transport activities; activities of travel agencies (63)

Post and telecommunications (64)

Financial intermediation, except insurance and pension funding (65)

Insurance and pension funding, except compulsory social security (66)

Activities auxiliary to financial intermediation (67)

Real estate activities (70)

Renting of machinery and equipment without operator and of personal and household goods (71)

Computer and related activities (72)

Research and development (73)

Other businesses activities (74)

Adjusted $\mathrm{R}^{2}$ of the wage regression

F-test relative to the wage regression

F-test relative to the sectoral dummies

Per cent significant industry wage differentials at the 5 per cent

level

Number of industries

Number of observations

\begin{tabular}{|c|c|c|}
\hline$(0.006)$ & $(0.005)$ & $(0.005)$ \\
\hline-0.003 & $0.008^{*}$ & $0.016 * *$ \\
\hline$(0.003)$ & $(0.004)$ & $(0.003)$ \\
\hline$-0.110 * *$ & $-0.088 * *$ & $-0.062 * *$ \\
\hline$(0.006)$ & $(0.004)$ & $(0.004)$ \\
\hline$-0.097 * *$ & $-0.125^{*} *$ & $-0.143 * *$ \\
\hline$(0.009)$ & $(0.006)$ & $(0.005)$ \\
\hline$-0.059 * *$ & $-0.088 * *$ & $-0.075^{* *}$ \\
\hline$(0.008)$ & $(0.005)$ & $(0.006)$ \\
\hline $0.180 * *$ & $0.109 * *$ & 0.019 \\
\hline$(0.024)$ & $(0.005)$ & $(0.018)$ \\
\hline $0.159 * *$ & $0.105 * *$ & $0.134 * *$ \\
\hline$(0.029)$ & $(0.018)$ & $(0.027)$ \\
\hline $0.031 * *$ & -0.004 & $0.010^{*}$ \\
\hline$(0.007)$ & $(0.007)$ & $(0.005)$ \\
\hline $0.254 * *$ & -0.016 & $0.059 * *$ \\
\hline$(0.030)$ & $(0.012)$ & $(0.010)$ \\
\hline $0.113^{* *}$ & $0.063 * *$ & $0.061 * *$ \\
\hline$(0.004)$ & $(0.005)$ & $(0.005)$ \\
\hline $0.054 * *$ & $0.031 * *$ & $0.073 * *$ \\
\hline$(0.006)$ & $(0.007)$ & $(0.007)$ \\
\hline 0.009 & $0.032 *$ & $0.035 * *$ \\
\hline$(0.013)$ & $(0.014)$ & $(0.011)$ \\
\hline 0.004 & -0.009 & $0.040 * *$ \\
\hline$(0.022)$ & $(0.011)$ & $(0.015)$ \\
\hline$-0.035^{*}$ & $0.028^{*}$ & 0.013 \\
\hline$(0.016)$ & $(0.012)$ & $(0.013)$ \\
\hline 0.006 & $-0.018 *$ & $0.022 * *$ \\
\hline$(0.008)$ & $(0.007)$ & $(0.006)$ \\
\hline $0.056 * *$ & $0.074 * *$ & $0.047 * *$ \\
\hline$(0.015)$ & $(0.010)$ & $(0.011)$ \\
\hline $0.009^{*}$ & $0.021 * *$ & $0.015 * *$ \\
\hline$(0.004)$ & $(0.004)$ & $(0.004)$ \\
\hline 0.701 & 0.648 & 0.613 \\
\hline $1,191.9 * *$ & $1,090.2 * *$ & $884.4^{* *}$ \\
\hline $137.6^{* *}$ & $141.4^{* *}$ & $116.3^{* *}$ \\
\hline $72.1 \%$ & $76.7 \%$ & $90.9 \%$ \\
\hline$(31 / 43)$ & $(33 / 43)$ & $(40 / 44)$ \\
\hline 43 & 43 & 44 \\
\hline 67,023 & 108,677 & 102,594 \\
\hline
\end{tabular}

Notes: Inter-industry wage differentials are estimated on the basis of equation (1) where the dependent variable is the $\ln$ of individual gross hourly wages excluding annual bonuses. Standard errors of the industry wage differentials, computed according to Zanchi (1998), are reported between brackets. **/*/o: industry wage differential significant at the 1,5 and 10 per cent level, respectively.

Results show, for all periods, the existence of substantial wage differentials between workers employed in different sectors, even after controlling for a large number of individual and establishment characteristics. These differentials are statistically significant at the 5 per cent level, both in individual terms (with a few exceptions) and globally. We further note that the hierarchy of the sectors in terms of wages is quite stable over time. Indeed, results reported in Table 4 show that the Pearson and Spearman correlation coefficients between the wage differentials estimated in 1995, 1999 and 2002 reach at least 0.75 , with a probability of being 
zero of less than 1 per cent. ${ }^{16}$ These correlations suggest that the estimated wage differentials between industrial sectors do not derive from transitory differences in demand across industries.

Table 4: Pearson / Spearman Correlation Coefficients

Between Inter-Industry Wage Differentials

\begin{tabular}{l|cc}
\hline Period: & 1995 & 2002 \\
\hline 1999 & $0.805^{* *} / 0.816^{* *}$ & $0.876^{* *} / 0.758^{* *}$ \\
& $(\mathrm{n}=43)$ & $(\mathrm{n}=42)$ \\
2002 & $0.805^{* *} / 0.780^{* *}$ & \\
& $(\mathrm{n}=42)$ &
\end{tabular}

Notes: Computation based on the inter-industry wage differentials reported in Table 2.

$\mathrm{n}$ stands for the number of sectors. ${ }^{* * / * / 0}$ : coefficient significant at the 1,5 and 10 per cent, respectively.

The best paying industry over the period 1995-2002 is the electricity, gas, steam and hot water supply sector. Depending on the period considered, the average worker in this sector earns ceteris paribus between 27 and 31 per cent ${ }^{17}$ more than the average worker in the whole economy. At the top of the conditional wage distribution, we also find the manufacture of coke, refined petroleum products and nuclear fuel industry (between +20 and 34 per cent), the air transport sector (between +12 and 19 per cent), the manufacture of chemicals and chemical products industry (between +11 and 12 per cent), and financial intermediaries, except insurance and pension funding (between +6 and 13 per cent).

The hotel and restaurant sector is at the very bottom of the wage scale: the average worker's wage there is ceteris paribus between 11 and 14 per cent lower than that of the average worker in the economy. At the bottom of the scale, we also find the manufacture of wearing apparel, dressing and dyeing of fur (between -11 and -13 per cent), retail trade (between -7

\footnotetext{
${ }^{16}$ Similar results are obtained when the inter-industry wage differentials are computed at the Nace three-digit level and/or on the basis of a wage equation where the dependent variable is the gross hourly wage including annual bonuses (see Appendix 8 and 9).

${ }^{17}$ In order to get the difference in percentage between the wage (in EUR) of the average worker in sector $k$ and the employment-share weighted mean wage (in EUR) in the economy, the following expressions have been computed : $V_{k}=\left[\left(\exp \left(\hat{\psi}_{k}\right)-1\right)-G\right]$ for $k=1, \ldots, K$ and $V_{K+1}=-G ;$ where $G=\sum_{k=1}^{K} \bar{p}_{k}\left[\exp \left(\hat{\psi}_{k}\right)-1\right]$. This transformation, often omitted in the literature, is necessary because the estimated wage equation has a semilogarithmic form (for a discussion see Reilly and Zanchi, 2003).
} 
and -12 per cent), the manufacture of furniture (between -8 and -10 per cent), and the manufacture of textiles (between -4 and -8 per cent).

If we compare these results with those obtained by Gannon et al. (2005) for six member states of the European Union on the basis of the 1995 European Structure of Earnings Survey (ESES), we find that the sectoral wage structure reported for Belgium is quite similar to that observed in other industrialised countries. To put it differently, it appears that high- and lowpaying industries do not vary substantially across countries.

Table 5: Dispersion of Inter-Industry Wage Differentials, 1995-2002

\begin{tabular}{llll}
\hline & 1995 & 1999 & 2002 \\
\hline $\begin{array}{l}\text { Range: } \\
\quad \begin{array}{l}\text { Nace two-digit industries } \\
\text { Nace three-digit industries }\end{array}\end{array}$ & 0.363 & 0.396 & 0.381 \\
& 0.599 & 0.552 & 0.570 \\
WASD: & & & \\
$\quad$ Nace two-digit industries & 0.071 & 0.064 & 0.057 \\
Nace three-digit industries & 0.084 & 0.080 & 0.072
\end{tabular}

Notes: Results are based on a wage equation where the dependent variable is the ln of individual gross hourly wages excluding annual bonuses. WASD stands for weighted adjusted standard deviation of inter-industry wage differentials. At the Nace two-digit level, the number of sectors varies between 42 and 43 depending on the year considered. At the three-digit level, it fluctuates between 172 and 180.

What about the dispersion of inter-industry wage differentials? Table 5 shows that the range and weighted adjusted standard deviation (WASD) of the industry wage differentials estimated in 1995, 1999 and 2002 at the Nace two- and three-digit level. Not surprisingly, it is found that the dispersion in industry wage differentials grows significantly when the number of sectors being considered increases. We also note that the WASD has steadily and substantially decreased between 1995 and 2002, both at the Nace two- and three-digit level. ${ }^{18}$ The explanation for this evolution is still unsettled. However, it could be related to the European integration process and the deregulation of certain industries. If we compare our results with those obtained for other industrialised countries (see, for example, Teulings and Hartog, 1998), we find that Belgium occupies a middle position among the industrialised countries with regard to the dispersion of the inter-industry wage differentials. The scale of

\footnotetext{
${ }^{18}$ A similar result is found when inter-industry wage differentials are estimated on the basis of a wage equation where the dependent variable is the $1 n$ of individual gross hourly wages including annual bonuses (see Appendix 6 and 7).
} 
the latter is indeed lower than in the Anglo-Saxon countries (UK, US and Canada) and higher than those in the Scandinavian countries.

\section{THE UNOBSERVED QUALITY EXPLANATION}

Findings reported so far emphasize the existence of substantial and persistent wage differentials among workers with the same observed characteristics, employed in different sectors. At face value, these results are incompatible with the assumption of a perfectly competitive labour market. Indeed, they suggest that individual wages are not solely determined by personal productive characteristics and task descriptions but also by the specific features of the employers in each sector. Yet, caution is required as industry wage differentials may derive from the fact that the unobserved quality of the labour force is not randomly distributed across sectors. In other words, high-paying industries might simply be those in which the non-observed quality of the labour force is the highest.

Almost all studies examining the unobserved quality explanation rely on panel data. They compute industry wage premia on the basis of a wage equation estimated in first-differences so as to control for time-invariant unobserved individual ability. Results arising from these studies are mixed. Krueger and Summers (1988), for example, show for the US that the magnitude of the industry wage differentials is almost undiminished when estimating wage equations in first-differences rather than in levels. A similar result has been reported by Gibbons and Katz (1992) on the basis of US data from plant closings. In contrast, Murphy and Topel (1990), Abowd et al. (1999) and Goux and Maurin (1999) show that individual fixed effects explain a large fraction of the estimated industry wage differentials in the US and France, respectively. Using longitudinal data from the British Household Panel Survey, Benito (2000) and Carruth et al. (2004) also provide strong evidence in favour of the unobserved quality explanation.

Longitudinal data allow to control for fixed unobserved individual characteristics. This is a major advantage with respect to cross-sectional data. Yet, the use of panel data generates specific problems that are not encountered with cross-sectional data. Indeed, first-difference estimates may be biased if: i) the number of workers changing industry is small, ii) workers who switch industry have non random characteristics, and iii) the unobserved labour quality is not equally valued among industries. Fixed effects estimations are also more affected by 
measurement errors (i.e. errors in reporting changes in workers' sectoral affiliation) since they exclusively focus on individuals switching industry. A final issue concerns the return-totenure component of the wage equation (Björklund et al., 2004). Indeed, it is argued that fixed effects estimates are biased since the tenure effect is likely to be underestimated among individuals who just switched industry.

To avoid the problems encountered with first-difference estimates, Björklund et al. (2004) examined the role of unobserved ability in explaining inter-industry wage differentials using data on siblings (brothers). The authors argue that industry wage premia computed from data on siblings are more accurate than those estimated on the basis of individuals switching industry because they do not depend on the exogenous job mobility assumption. Their results show that unobserved ability accounts for approximately 50 per cent of the industry wage dispersion in the US and for between 11 and 24 per cent in the Scandinavian countries. Furthermore, in contrast to virtually all previous studies, the authors find that the contribution of industry wage differentials to the overall wage variation is not significantly larger in the US than in the Scandinavian countries, after controlling for unobserved factors common to brothers.

The unobserved quality explanation has also been tested by Martins (2004). Applying quantile regressions to a Portuguese matched employer-employee data set from 1995, the author rejects the hypothesis that high-wage industries draw disproportionately more on highability workers. Therefore, he concludes that non-competitive forces may play an important role in the wage determination process.

\subsection{Methodology}

The unobserved ability hypothesis has never been tested for the Belgian economy. This is partly due to the fact that linked employer-employee panel data are not available for Belgium. In this section, we attempt to fill this gap by applying Martins' (2004) methodology to the 1995 and 2002 Structure of Earnings Surveys. This boils down to estimate an extended wage equation, controlling for a large number variables, at the mean and at the 10th and 90th 
percentiles of the wage distribution. ${ }^{19}$ Martins' methodology is based on the following reasoning. On the one hand, workers with better unobserved characteristics (e.g. ability, motivation, industry-specific skills) are likely to be found at the top of the conditional wage distribution. On the other hand, according the unobserved quality explanation, workers with better unmeasured characteristics are over-represented in high-wage sectors. As a result if the unobserved quality explanation is valid, we would expect: i) industry wage differentials to be larger at the top end of the wage distribution, ii) a bigger difference in industry wage premia across the wage distribution in high-wage sectors than in low-wage sectors, and iii) a highly positive correlation between industry wage differentials computed at the mean and at the 90th percentile of the wage distribution (or equivalently, a strong positive correlation between the mean premia and the difference between the premia at the top and bottom percentiles).

Our wage equation is specified as in section 4 (see equation (1)). The dependent variable is the log (to base e) of individual gross hourly wages including bonuses. The inclusion of bonuses is justified by the fact that they are likely to be affected by unobserved characteristics (e.g. ability, motivation, industry-specific skills). ${ }^{20}$ Among the explanatory variables we find: i) a vector of workers' individual characteristics and working conditions (6 dummy variables showing the highest completed level of education; prior potential experience, its square and its cube; seniority within the current company and its square; sex; 22 occupational dummies; number of hours paid; an indicator showing whether the individual is paid a bonus for shift work, night-time and/or weekend work; a dummy for extra paid hours; 3 dummies for the type of contract; and a dichotomic variable indicating whether the individual supervises other workers ${ }^{21}$ ); ii) Nace two-digit dummy variables relating to the sectoral affiliation of the workers; and iii) a vector of employer's characteristics (2 regional dummies indicating where

\footnotetext{
${ }^{19}$ We applied a method where the wage equation is calculated simultaneously at the 10th and 90th percentiles. This method estimates a bootstrapped version of the variance-covariance matrix which enables to test whether regression coefficients are significantly different across percentiles. Bootstrapped standard errors are better than those computed analytically when estimating quantile regressions. This is due to the fact that the variance of the error term is assumed to vary along the conditional wage distribution. For an extended description of quantile regressions and bootstrapping see StataCorp (1999) and Wooldridge (2002).

${ }^{20}$ Information on annual bonuses is not available in the 1999 wave of the SES. Therefore, our analysis focuses exclusively on 1995 and 2002.

${ }^{21}$ This variable is only available in the 1995 wave of the SES.
} 
the establishment is located; the size of the establishment; and 2 dummies for the level of wage bargaining). ${ }^{22}$

\subsection{Empirical Results}

Table 6 presents the industry wage coefficients at the 10th and 90th percentiles of the wage distribution and the difference between the two percentiles at each industry in 2002. Results show that almost 40 per cent of the industry wage differentials are not significantly different (at the 5 per cent level) at the top and bottom of the conditional wage distribution. However, on average industry wage premia are larger at the 90th percentile than at the 10th percentile (0.106 vs. 0.063$)$. Also noteworthy is that high-wage industries are characterised by bigger differences in wage premia between the top and bottom percentiles. Indeed, the average differential stands at 0.086 for the 15 best-paying industries (ranked according to the OLS results), while the same average is equal to 0.011 for the 15 worse-paying industries. Final results show the existence of a positive and significant relationship between mean industry wage premia and differences in wage premia across the wage distribution.

Table 6: Industry Coefficients at the Top and Bottom Percentiles of the Wage Distribution and their Difference, 2002

\begin{tabular}{|c|c|c|c|}
\hline Industry (NACE two-digit): & $\begin{array}{c}\text { 10th } \\
\text { percentile }\end{array}$ & $\begin{array}{c}\text { 90th } \\
\text { percentile }\end{array}$ & $\begin{array}{l}\text { Difference between } \\
90 \text { th and } 10 \text { th } \\
\text { percentiles }\end{array}$ \\
\hline Mining of coal and lignite; extraction of peat (10) & $\begin{array}{l}-0.043 \\
(0.034)\end{array}$ & $\begin{array}{c}-0.097 * * \\
(0.04)\end{array}$ & $\begin{array}{l}-0.055 \\
(0.050)\end{array}$ \\
\hline Other mining and quarrying (14) & $\begin{array}{l}0.083 * * \\
(0.005)\end{array}$ & $\begin{array}{l}0.109 * * \\
(0.010)\end{array}$ & $\begin{array}{l}0.026 * * \\
(0.010)\end{array}$ \\
\hline Manufacture of tobacco products (16) & $\begin{array}{l}0.097 * * \\
(0.018)\end{array}$ & $\begin{array}{l}0.138 * * \\
(0.03)\end{array}$ & $\begin{array}{c}0.041 \\
(0.031)\end{array}$ \\
\hline Manufacture of textiles (17) & $\begin{array}{c}-0.032 * * \\
(0.007)\end{array}$ & $\begin{array}{l}0.030 * * \\
(0.01)\end{array}$ & $\begin{array}{l}0.062 * * \\
(0.013)\end{array}$ \\
\hline $\begin{array}{l}\text { Manufacture of wearing apparel; dressing and dyeing } \\
\text { of fur (18) }\end{array}$ & $\begin{array}{c}-0.095 * * \\
(0.007)\end{array}$ & $\begin{array}{l}0.044^{\circ} \\
(0.02)\end{array}$ & $\begin{array}{c}0.139 * * \\
(0.025)\end{array}$ \\
\hline $\begin{array}{l}\text { Tanning and dressing of leather; manufacture of } \\
\text { luggage, handbags, saddlery, harness and footwear } \\
\text { (19) }\end{array}$ & $\begin{array}{c}-0.043 * \\
(0.018)\end{array}$ & $\begin{array}{c}-0.031^{\circ} \\
(0.02)\end{array}$ & $\begin{array}{c}0.011 \\
(0.024)\end{array}$ \\
\hline $\begin{array}{l}\text { Manufacture of wood and products of wood and cork, } \\
\text { except furniture; manufacture of articles of straw and } \\
\text { plaiting materials }(20)\end{array}$ & $\begin{array}{l}0.014^{\circ} \\
(0.007)\end{array}$ & $\begin{array}{c}-0.045 * * \\
(0.01)\end{array}$ & $\begin{array}{c}-0.059 * * \\
(0.013)\end{array}$ \\
\hline Manufacture of pulp, paper and paper products (21) & $\begin{array}{c}0.097 * * \\
(0.008)\end{array}$ & $\begin{array}{c}0.151 * * \\
(0.01)\end{array}$ & $\begin{array}{c}0.054 * * \\
(0.016)\end{array}$ \\
\hline $\begin{array}{l}\text { Publishing, printing and reproduction of recorded } \\
\text { media }(22) \\
\text { Manufacture of coke, refined petroleum products and }\end{array}$ & $\begin{array}{l}0.113 * * \\
(0.011) \\
0.134 * *\end{array}$ & $\begin{array}{l}0.177 * * \\
(0.01) \\
0.321 * *\end{array}$ & $\begin{array}{l}0.064 * * \\
(0.017) \\
0.187 * *\end{array}$ \\
\hline
\end{tabular}

\footnotetext{
${ }^{22}$ Results from the regressions can be obtained upon request.
} 
nuclear fuel (23)

Manufacture of chemicals and chemical products (24)

(0.017)

$0.088 * *$

(0.006)

Manufacture of rubber and plastic products (25)

Manufacture of other non-metallic mineral products

(26)

Manufacture of basic metals (27)

Manufacture of fabricated metal products, except

machinery and equipment (28)

Manufacture of machinery and equipment n.e.c. (29)

Manufacture of office machinery and computers (30)

Manufacture of electrical machinery and apparatus

n.e.c. (31)

Manufacture of radio, television and communications

equipment and apparatus (32)

Manufacture of medical, precision and optical

instruments, watches and clocks (33)

Manufacture of motor vehicles, trailers and semi-

trailers (34)

Manufacture of other transport equipment (35)

Manufacture of furniture; manufacturing n.e.c. (36)

Recycling (37)

Electricity, gas, steam and hot water supply (40)

Collection, purification and distribution of water (41)

Construction (45)

Sale, maintenance and repair of motor vehicles and motorcycles; retail sale of automotive fuel (50)

Wholesale trade and commission trade, except of motor vehicles and motorcycles (51)

Hotels and restaurants (55)

Land transport; transport via pipelines (60)

Water transport (61)

Air transport (62)

Supporting and auxiliary transport activities; activities of travel agencies (63)

Post and telecommunications (64)

Financial intermediation, except insurance and pension funding (65)

Insurance and pension funding, except compulsory social security (66)

Activities auxiliary to financial intermediation (67)

Real estate activities (70)

Renting of machinery and equipment without operator
$0.056 * *$

$(0.007)$

$0.071 * *$

(0.007)

$0.045^{* *}$

$(0.009)$

$0.067 * *$

(0.006)

$0.096 * *$

(0.006)

0.041

(0.026)

$0.087 * *$

(0.007)

$0.112 * *$

(0.009)

$0.056^{* *}$

$(0.011)$

0.100 **

(0.006)

$0.081 * *$

(0.009)

$-0.051 * *$

(0.007)

0.046 **

(0.010)

$0.232 * *$

(0.041)

$0.382 * *$

(0.064)

$0.063 * *$

(0.006)

$0.107 * *$

(0.007)

$0.044 * *$

(0.005)

$-0.113 * *$

(0.008)

$-0.088^{* *}$

(0.009)

$0.098 * *$

(0.026)

$-0.030$

(0.029)

$0.019^{*}$

(0.008)

$0.046^{* *}$

(0.009)

$0.157^{* *}$

(0.008)

$0.179 * *$

(0.010)

$0.058 * *$

(0.015)

$0.049 * *$

(0.019)

$0.075^{* *}$
(0.03)

$0.233 * *$

(0.01)

$0.077 * *$

(0.01)

$0.128 * *$

$(0.01)$

$0.116^{* *}$

(0.01)

$0.068 * *$

$(0.01)$

$0.082 * *$

$(0.01)$

$-0.091 * *$

$(0.03)$

$0.069 * *$

(0.01)

$0.176^{* *}$

(0.02)

$0.088 * *$

(0.01)

$0.051 * *$

(0.01)

0.050 **

(0.02)

$-0.015$

$(0.01)$

$0.041^{\circ}$

(0.02)

$0.487 * *$

(0.02)

0.279

(0.36)

$0.058 * *$

(0.01)

$0.103 * *$

(0.01)

$0.142 * *$

(0.01)

$-0.100 * *$

(0.01)

0.012

(0.01)

$0.114 * *$

(0.03)

$0.366^{* *}$

(0.05)

$0.140 * *$

(0.01)

$0.194 * *$

(0.02)

$0.148^{* *}$

(0.01)

$0.145^{* *}$

(0.01)

$0.138 * *$

(0.02)

$0.086 * *$

(0.02)

$0.109 * *$
(0.036)

$0.144 * *$

(0.012)

0.021

(0.015)

$0.056^{* *}$

(0.013)

0.071 **

(0.016)

0.001

(0.008)

$-0.015$

(0.011)

$-0.132 * *$

(0.040)

$-0.018$

(0.013)

$0.064 * *$

(0.021)

0.031 *

(0.015)

$-0.049 * *$

(0.012)

$-0.031^{\circ}$

(0.018)

$0.036^{* *}$

(0.013)

$-0.005$

(0.024)

$0.256 * *$

(0.044)

$-0.104$

(0.371)

$-0.005$

(0.010)

$-0.003$

(0.011)

$0.098 * *$

(0.009)

0.013

(0.012)

$0.100 * *$

(0.013)

0.017

(0.044)

$0.396 * *$

(0.057)

$0.121 * *$

(0.015)

$0.148 * *$

(0.027)

$-0.008$

(0.012)

$-0.034 *$

(0.016)

0.080 **

(0.027)

0.037

$(0.029)$

0.034* 


\begin{tabular}{lccc} 
and of personal and household goods (71) & $(0.010)$ & $(0.01)$ & $(0.017)$ \\
Computer and related activities (72) & $0.053^{* *}$ & $0.100^{* *}$ & $\begin{array}{c}0.047^{* *} \\
(0.016)\end{array}$ \\
& $(0.009)$ & $(0.01)$ & $-0.075^{* *}$ \\
Research and development (73) & $0.132^{* *}$ & $0.057^{* *}$ & $(0.026)$ \\
& $(0.016)$ & $(0.02)$ & $0.115^{* *}$ \\
Other businesses activities (74) & $0.012^{*}$ & $0.126^{* *}$ & $(0.010)$ \\
\hline $\begin{array}{l}\text { Means } \\
\text { Average difference for the 15 best-paying industries }\end{array}$ & $0.006)$ & 0.106 & 0.044 \\
$\begin{array}{l}\text { Average difference for the 15 worse-paying industries } \\
\text { Per cent significant coefficients at the 5 per cent level }\end{array}$ & & & 0.086 \\
$\begin{array}{l}\text { Correlation between OLS and quantile regression } \\
\text { coefficients (Spearman) }\end{array}$ & $90.7 \%$ & $86.0 \%$ & 0.011 \\
$\begin{array}{l}\text { Correlation between OLS and quantile regression } \\
\text { coefficients (Pearson) }\end{array}$ & $0.702^{* *}$ & $0.900^{* *}$ & $62.8 \%$ \\
\hline
\end{tabular}

Notes: Industry wage coefficients are estimated on the basis of equation (1) where the dependent variable is the ln of individual gross hourly wages including annual bonuses. Bootstrapped standard errors are reported between brackets (1000 iterations). ${ }^{* * / * / 0}$ : coefficient significant at the 1,5 and 10 per cent level, respectively.

These findings are compatible with the unobserved ability hypothesis. Yet, caution is required. Indeed, almost 40 per cent of the industry coefficients are not significantly larger at the top end of the wage distribution. Moreover, top and bottom industry coefficients are correlated with the same intensity to the mean industry wage premia. However, according to the unobserved ability hypothesis, the correlation should have been non significant or at least lower with the bottom percentile wage coefficients. A final concern is that the correlation between mean and inter-percentile industry premia is smaller than expected (around 30 per cent).

In sum, we may not reject the hypothesis that part of the industry wage differentials derives from unobserved characteristics that are not randomly distributed across sectors. Yet, we should recognise that results are not clear-cut. This tends to indicate that the contribution of unobserved ability to the industry wage differentials is limited. ${ }^{23}$

\section{Industry Wage Differentials ANd Sectoral Heterogeneity in 'ABILITY to Pay'}

Findings so far show that substantial wage differentials exist between workers, with identical observed individual characteristics and working conditions, employed in different sectors. These differentials appear to be only partially compatible with the unobserved ability hypothesis. Therefore, the role of non-competitive forces deserves to be addressed. The most

\footnotetext{
${ }^{23}$ An identical analysis was carried out for the year 1995. The results arising from this, set out in the Appendix 10 , support our conclusion.
} 
natural non-competitive explanation for the existence of industry wage premia is that they result from inter-sectoral variations in 'ability to pay', i.e. profits. This explanation is generally supported by the literature. For example, Kouwenberg and van Opstal (1999) show that industry wage differentials in the Netherlands are positively and significantly correlated to industry profits. A similar result is reported for the UK by Benito (2000) and for six member states of the European Union by Gannon et al. (2005). Genre et al. (2005), on the opposite, find no significant relationship between industry wage premia and sectoral profits in the euro area. However, this may be due to some data shortcomings, in particular a high level of aggregation.

In this section, we attempt to provide additional insights into the nature of industry wage differentials in Belgium by considering their relation with industry profitability. Data on profitability are taken from the Structure of Earnings Survey (SBS). Industry profitability is estimated by the gross operation surplus per worker.

Table 7 : Correlation between Industry Wage Differentials and Industry Profitability

$1995 \quad 1999 \quad 2002$

$\begin{array}{llll}\begin{array}{l}\text { Nace two-digit industries: } \\ \text { Pearson } \\ \text { Spearman }\end{array} & 0.449 * * & 0.560^{* *} & 0.627 * * \\ & 0.457 * * & 0.509 * * & 0.645^{* *} \\ & & & \\ \begin{array}{l}\text { Nace three-digit industries: } \\ \quad \text { Pearson } \\ \text { Spearman }\end{array} & 0.490^{* *} & 0.531^{* *} & 0.302 * * \\ & 0.472 * * & 0.539 * * & 0.390^{* *}\end{array}$

Notes: Data on industry profitability are drawn from the Structure of Business Survey. The industry profitability has been estimated by the industry level gross operating surplus per employee. Industry wage differentials have been computed on the basis of equation (1) where the dependent variable is the ln of gross hourly wages excluding annual bonuses. Similar results are found when the dependent variable includes annual bonuses (see Appendix 11). $* * / * /{ }^{\circ}$ : coefficient significant at the 1,5 and 10 per cent level, respectively.

Table 7 shows that industry wage differentials are significantly and positively correlated with industry profitability in all periods, both at the Nace two- and three digit level. The magnitude of this correlation fluctuates between 0.302 and 0.645 . It is not found to be significantly different at the top and bottom of the conditional wage distribution (see Appendix 11). Industry wage premia computed at the 10th and 90th percentiles of the wage distribution are indeed correlated with the same intensity to industry profits. 
Table 8: OLS Regressions - The Effect of Industry Profitability on Industry Wage Differentials at the Nace Three-Digit Level

\begin{tabular}{|c|c|c|c|c|}
\hline Explanatory variables / Period: & 1995 & 1999 & 2002 & $\begin{array}{c}\text { Pooled data } \\
(1995,1999 \\
\text { and 2002) }\end{array}$ \\
\hline Intercept & $\begin{array}{c}-0.041^{* *} \\
(0.009)\end{array}$ & $\begin{array}{c}-0.053^{* *} \\
(0.008)\end{array}$ & $\begin{array}{c}-0.027^{* *} \\
(0.007)\end{array}$ & $\begin{array}{c}-0.036^{* *} \\
(0.007)\end{array}$ \\
\hline Profits-per-worker (millions of EUR) & $\begin{array}{l}1.44 * * \\
(0.22)\end{array}$ & $\begin{array}{l}1.86^{* *} \\
(0.26)\end{array}$ & $\begin{array}{c}0.64 * * \\
(0.17)\end{array}$ & $\begin{array}{l}1.16^{* *} \\
(0.12)\end{array}$ \\
\hline Dummy for 1999 & - & - & - & $\begin{array}{c}-0.001 \\
(0.009)\end{array}$ \\
\hline Dummy for 2002 & - & - & - & $\begin{array}{l}-0.005 \\
(0.009)\end{array}$ \\
\hline F-test & $41.3^{* *}$ & $51.3 * *$ & $14.2 * *$ & $29.75^{* * *}$ \\
\hline Adjusted $\mathrm{R}^{2}$ & 0.234 & 0.276 & 0.085 & 0.175 \\
\hline Number of observations & 133 & 133 & 143 & 409 \\
\hline
\end{tabular}

Notes: Industry wage differentials (at the Nace three-digit level) are the dependent variable. They have been computed on the basis of equation (1) where the explained variable is the ln of gross hourly wage excluding annual bonuses. The industry profitability has been estimated by the industry level gross operating surplus per employee. White (1980) heteroscedasticity-consistent standard errors are reported between brackets. $* * / * / 0$ : coefficient significant at the 1,5 and 10 per cent level, respectively.

These results are supported by cross-sectional regressions run for each period separately and for all periods together (see Table 8). Regressions estimated by OLS with White (1980) heteroscedasticity-consistent standard errors show that sectoral profits (at the Nace three-digit level) have a positive and significant effect on industry wage premia. ${ }^{24}$ Depending on the period under investigation, we find that when sectoral profits-per-capita rise by 10,000 EUR industry wage premia increase on average by between 0.0064 and $0.0186 \log$ points. This means that the wage premium of the average worker in a sector where profits-per-capita raise by 10,000 EUR increases on average by between 1 and 2 percentage points with respect to the average worker in the whole economy. ${ }^{25}$ The magnitude of this effect is not found to vary along the wage distribution (see Appendix 15). Finally, let us notice that the heterogeneity in profits-per-capita across sectors explains between 8.5 and 27.6 per cent of the variability in inter-industry wage differentials.

\footnotetext{
${ }^{24}$ Similar results are obtained when industry wage differentials are computed at the Nace two-digit level and/or on the basis of a wage equation where the dependent variable is the gross hourly wage including annual bonuses. We also estimated our regression model using fixed effects. Results from this specification were not statistically significant (see Appendix 12, 13 and 14). However, this is probably due to the fact that our variables do not very much fluctuate over time.

${ }^{25}$ Yet, the elasticity between industry wage premia and sectoral profits should be regarded with caution. Indeed, it might be downward biased since by construction higher wages lead to lower profits. This issue is addressed in the next section of the paper.
} 
All in all, results show that industry wage premia derive at least partly from sectoral differences in 'ability-to-pay', i.e. profits. These results are consistent with several noncompetitive wage determination models, including efficiency wage mechanisms and rentsharing.

\section{INDUSTRY WAGE DIFFERENTIALS AND RENT-SHARING}

In this section, we attempt to go a step further by examining to what extent industry wage differentials are explained by a rent-sharing phenomenon. As far as we know, very little is known on this issue. Our methodology boils down to compare (at different percentiles) the magnitude and dispersion of inter-industry wage differentials estimated from two different wage equations. The first one is the same as in section 4. It involves to regress individual gross hourly wages on workers' characteristics (e.g. education, potential experience, tenure, sex, and occupation), working conditions (e.g. type of contract and working hours), industry dummies (at the Nace two- and three-digit level), and employers' features (e.g. size of the establishment and level of wage bargaining). The second wage equation includes a supplementary explanatory variable, i.e. firm level profits-per-employee. Controlling for this additional variable requires to correct for group effects in the residuals and to use instrumental variables to correct for the endogeneity of profits. The analysis in this section is based on the combination of the SES and the SBS at the firm level in $1995 .{ }^{26}$ Descriptive statistics relative to this sample are reported in the Appendix 2.

Before examining the contribution of rent-sharing to the observed industry wage differentials, we briefly present our estimates of the elasticity between wages and profits (at different percentiles) as well as the underlying theoretical framework.

\subsection{Theoretical Framework}

Two models have become standard in the literature for the analysis of the impact of profitsper-employee on wages in a bargaining framework. These are the right-to-manage and the efficient bargaining models, so-named respectively by Nickell and Andrews (1983) and

\footnotetext{
${ }^{26}$ Data from the SBS for 1999 and 2002 are only available at the sectoral level. Therefore, the analysis in this section is restricted to the year 1995 .
} 
McDonald and Solow (1981). In the right-to-manage model, firms unilaterally determine employment, while wages are the result of a confrontation between the objectives of the firm and of the employees. In the efficient bargaining model, bargaining takes place with respect to both employment and wages. While both models yield identical wage equations, they differ fundamentally in that in the former employment is endogenous with respect to wages whereas in the latter it is exogenous. Nevertheless, they both suggest that wages are related to the firm's ability to pay, i.e. to the firm's profitability. ${ }^{27}$

In this section, we rely on the right-to-manage model. ${ }^{28}$ Hence, suppose a bargaining situation where a firm's real profit function is given by:

$$
\Pi=R(L)-W L
$$

with $\Pi$ the real profits, $R(L)$ the real revenue, $W$ the real wage and $L$ the employment level. Also consider a risk-neutral group of workers, not necessarily a union, which attempts to maximize the expected utility of a representative member, defined as:

$$
U=\frac{L}{N} W+\left(1-\frac{L}{N}\right) A
$$

with $N$ the number of members in the group $(0<L \leq N)$ and $A$ the outside option $(W>A)$. The outside option is the expected value of real revenue perceived by an individual in the event of redundancy. It depends positively on the unemployment benefit and on the expected real wage that a worker would obtain elsewhere, and negatively on the unemployment rate.

\footnotetext{
${ }^{27}$ See e.g. Pencavel (1991).

${ }^{28}$ Using Belgian aggregate data from 1957 to 1988, Vannetelbosch (1996) has shown that both the right-tomanage and the efficient bargaining models can be rejected in favour of the general bargaining model, developed by Manning (1987). This means that the outcome of the bargaining process is located somewhere between the labour demand curve and the contract curve. Nevertheless, this result must be considered with caution for at least two reasons. First, the estimates are very sensitive to the specification of the reservation wage, and second, the trade union density and the number of strikes are far from ideal as a surrogate for the relative bargaining power of unions. This uncertainty is not very surprising since "the empirical literature has not yet been able to find an appropriate test to distinguish between the principal models" (Booth, 1995: 141). Also noteworthy is that, while these models have different implications for unemployment and economic welfare, they generate identical wage equations. Hence, for the sake of simplicity, we have chosen to rely on the right-to-manage model.
} 
The model is solved backwards: the profit-maximizing firm determines the employment level, given the bargained wage in the first stage of the game. The resulting deal is represented by the maximisation of the generalised Nash bargain. This approach boils down to maximising the weighted product of both parties' net gain, i.e. the difference between levels of utility in the event of an agreement and in the event of no agreement. For a company, without fixed costs, the level of utility reached when bargaining fails equals zero. Indeed, since we assume that all workers are affiliated to the group, the company will have to cease production if agreement is not reached. The fallback position of a representative member of the group is equal to $A$. Accordingly, the generalised Nash bargaining problem can be written as follows ${ }^{29}$ :

$$
\begin{aligned}
& \underset{W}{\operatorname{Max}} U^{\beta} \Pi=\operatorname{Max}_{W}\left(\frac{L}{N}(W-A)\right)^{\beta}(R(L)-W L) \\
& \text { s.t. } R^{\prime}(L)=W
\end{aligned}
$$

with $\beta \in[0,1]$ the relative bargaining power of the workers in the wage bargain. The first order condition of this problem is given by:

$$
W=A+\beta \frac{(R(L)-W L)}{L}
$$

Expression (9) suggests that real wages are affected by the outside option, real profits-peremployee and the relative bargaining power of the workers.

\subsection{Elasticity between Wages and Profits}

The corresponding statistical specification, which will serve as a benchmark for our empirical analysis, can be written as follows:

$$
\ln w_{i}=\alpha+\lambda \ln (\Pi / L)_{f}+\sum_{j=1}^{J} \beta_{j} X_{j, i}+\sum_{k=1}^{K} \psi_{k} Y_{k, i}+\sum_{l=1}^{L} \delta_{l} Z_{l, i}+\varepsilon_{i}
$$

\footnotetext{
${ }^{29}$ See Nickell (1999: 3) for a discussion on the notation.
} 
with $w_{i}$ the gross hourly wage of the individual $i(i=1, \ldots, \mathrm{N}) ;(\Pi / L)_{f}$ the amount of profit-perworker in firm $f^{30} ; X$ the vector of the individual characteristics of the workers and their working conditions (6 dummy variables showing the highest completed level of education; prior potential experience, its square and its cube; seniority within the current company and its square; sex; 22 occupational dummies; number of hours paid; an indicator showing whether the individual is paid a bonus for shift work, night-time and/or weekend work; a dummy for extra paid hours; 3 dummies for the type of contract; and a dichotomic variable indicating whether the individual supervises other workers); $Y$ comprises dummy variables relating to the sectoral affiliation of the individuals (nomenclature available both at the Nace two- and three-digit level) ; $Z$ contains employer's characteristics (2 regional dummies indicating where the establishment is located; the size of the establishment; and 2 dummies for the level of wage bargaining); $\alpha$ is the intercept; $\lambda, \beta, \psi$ and $\delta$ are the parameters to be estimated and $\varepsilon_{i}$ is an error term (see Appendix 2 for a detailed description of the variables). ${ }^{31}$

Equation (10) has been estimated by OLS with White (1980) heteroscedasticity-consistent standard errors. Yet, a potential trap derives from the use of grouped observations and individual data. Indeed, profits are computed at the firm level while wages are reported at the worker level. This situation can bias the standard errors of our estimates and as a result distort the significance of the regression coefficients. To account for these group effects, we applied the correction for common variance components within groups, as suggested by Greenwald (1983) and Moulton (1990). ${ }^{32}$

\footnotetext{
${ }^{30}$ Firm profits are approximated by the firm annual gross operating surplus, i.e. the difference between the value added at factor costs and the total personnel expenses.

${ }^{31}$ This specification is standard in the economic literature (see e.g. Nekby, 2003). However, it could be argued that specific variables representing the outside option of the workers should be included in equation (10). To account for this potential omitted variable bias, we tested an alternative specification including among the explanatory variables the sector unemployment rate and the sector mean hourly wage. The intuition behind this choice is that when the sector unemployment rate diminishes, the probability of finding a job elsewhere goes up and therefore wage claims increase. In contrast, a drop in the expected alternative wage mitigates envy effects and wage claims. Findings (available upon request) show that the inclusion of these variables in our wage regressions has no impact on the wage-profit elasticity.

32 This has been done by applying the "cluster" option in Stata (StataCorp, 1999). Another potential issue is that cross-sectional data do not allow to control for the fact that more profitable firms may employ workers with better unobserved abilities. Yet, “even with panel data, Martins (2003) does not include firm fixed effects, and attempts to do so by Abowd et al. (1999) and Margolis and Salvanes (2001) have relied on the exogeneity of
} 
Table 9: Rent-Sharing at Different Percentiles of the Wage Distribution

(Dependent variable: Ln of individual gross hourly wages including annual bonuses)

\begin{tabular}{|c|c|c|c|c|c|}
\hline \multirow[t]{2}{*}{ Explanatory variables / Model: } & \multirow{2}{*}{$\begin{array}{l}\text { OLS }^{1} \\
\text { (1) } \\
\end{array}$} & \multirow{2}{*}{$\begin{array}{c}\text { IV } \\
(2 \mathrm{SLS})^{1,2} \\
(2) \\
\end{array}$} & \multicolumn{3}{|c|}{$\begin{array}{c}\text { Quantile regressions with } \mathrm{IV}^{2} \\
\text { (Bootstrapped standard errors, } \\
1000 \text { iterations) }\end{array}$} \\
\hline & & & $\begin{array}{c}\text { 10th } \\
\text { percentile } \\
(3) \\
\end{array}$ & $\begin{array}{c}50^{\text {th }} \\
\text { percentile } \\
(4)\end{array}$ & $\begin{array}{c}\text { 90th } \\
\text { percentile } \\
(5) \\
\end{array}$ \\
\hline Profits-per-worker $(\ln )^{3}$ & $\begin{array}{l}0.028 * * \\
(0.001)\end{array}$ & $\begin{array}{l}0.063^{* *} \\
(0.005)\end{array}$ & $\begin{array}{c}0.048 * * \\
(0.002)\end{array}$ & $\begin{array}{c}0.066 * * \\
(0.002)\end{array}$ & $\begin{array}{l}0.079 * * \\
(0.003)\end{array}$ \\
\hline Group effects ${ }^{4}$ & Yes & Yes & Yes & Yes & Yes \\
\hline $\begin{array}{l}\text { Individual characteristics and } \\
\text { working conditions } 5\end{array}$ & Yes & Yes & Yes & Yes & Yes \\
\hline Firm characteristics ${ }^{6}$ & Yes & Yes & Yes & Yes & Yes \\
\hline Industry effects ${ }^{7}$ & Yes & Yes & Yes & Yes & Yes \\
\hline Adjusted $\mathrm{R}^{2}$ / Pseudo $\mathrm{R}^{2}$ & 0.719 & 0.712 & 0.414 & 0.478 & 0.538 \\
\hline F-test & $314.2 * *$ & $512.1 * *$ & / & l & / \\
\hline $\begin{array}{l}\text { Test of over-identification } \\
\text { restrictions }\end{array}$ & l & $\begin{array}{c}3.497 \\
(0.174)\end{array}$ & / & / & / \\
\hline $\begin{array}{l}\text { Lester (1952) range of wages } \\
\text { (per cent) }\end{array}$ & 18.0 & 40.6 & l & / & / \\
\hline Number of observations & 34,972 & 34,972 & 34,972 & 34,972 & 34,972 \\
\hline Number of groups & 1,501 & 1,501 & 1,501 & 1,501 & 1,501 \\
\hline
\end{tabular}

Notes: ${ }^{1}$ White (1980) heteroscedasticity-consistent standard errors are reported between brackets. ${ }^{2}$ The instruments used in the IV regressions (besides the exogenous variables in equation (10)) include: per capita firm level value added and per capita total amount of goods and services purchased by the firm. ${ }^{3}$ Firm annual gross operating surplus per worker. ${ }^{4}$ Group effects estimations use the correction for common variance components within groups developed by Over, Jolliffe and Foster (1996) preprogrammed in the "cluster" option of Stata (StataCorp, 1999). ${ }^{5}$ Dummy for gender; 6 dummies for education; prior potential experience, its square and its cube; seniority within the current company and its square; dummy variable indicating whether the individual supervises other workers; a variable showing whether the individual received a bonus for shift work, night work and/or weekend work, a dummy for overtime paid, 3 dummies for the type of contract and 23 occupational dummies. ${ }^{6}$ Region where the establishment is located ( 2 dummies), size of the establishment (i.e. number of workers), and level of wage bargaining ( 2 dummies). ${ }^{7}$ Two-digit industry dummies for quantile regressions and three-digit industry dummies otherwise. ${ }^{8} \mathrm{n}^{*} \mathrm{R}^{\prime 2}$ and associated (p-value). $* * / * /{ }^{\circ}$ : coefficient significant at the 1 , 5 and 10 per cent level, respectively.

Our findings, reported in column (1) of Table $9^{33}$, show that the OLS estimate of $\lambda$, i.e. the elasticity between wages and profits-per-worker, is significant at the 1 per cent level and equal to 0.028 . This means that on average a doubling of profits-per-worker increases earnings ceteris paribus by 2.8 per cent. To evaluate the impact of profits on the distribution of wages, Lester's (1952) range of pay due to rent-sharing can be calculated. This statistic

individual moves between firms - an obviously questionable assumption that introduces other biases (WinterEbmer and Zweimueller, 1999)" (Fakhfakh and FitzRoy, 2004: 618).

${ }^{33}$ Detailed results for the 2SLS are presented in Appendix 16. Full results of the quantile regressions with IV can be obtained upon request. 
estimates the fraction of the overall wage inequality that is due to the variability in profitsper-worker. It is obtained by applying the following formula:

$$
4 \hat{\lambda} * \frac{\sigma(\Pi / L)}{\Pi / L}
$$

where $\hat{\lambda}$ is the estimated wage-profit elasticity, $\Pi / L$ measures the level of firm profits-perworker, and $\sigma(\Pi / L)$ and $\bar{\Pi} / L$ denote the standard deviation and the mean value of $\Pi / L$, respectively. On the basis of this formula, it appears that about 18 per cent of the variance in individual wages is due to the variability in profits. ${ }^{34}$ To put it another way, given that the mean hourly wage (including bonuses) stands at 13.46 EUR, rent sharing explains the variation of wages between 11.04 and 15.88 EUR.

Although these results seem quite accurate, they suffer from the endogeneity of profits. Indeed, by construction wages have a negative impact on profits. Therefore, OLS estimates are biased and inconsistent. To overcome this problem, we re-estimated our model using the method of instrumental variables. This method consists in finding instruments, which are at the same time highly correlated with the endogenous variable and uncorrelated with the error term. We used as instruments for profits all exogenous variables of equation (10), plus per capita firm level value added and per capita total amount of goods and services purchased by the firm. The sum of the latter variables corresponds to the firm level value of production per worker. As suggested by Margolis and Salvanes (2001: 16), one might think of sales (or production) per worker, conditional on the sector being correctly identified, as a measure of the firm's market power. ${ }^{35}$ Results of our 2SLS regression are presented in column (2) of Table 9. Not surprisingly, we find that the wage-profit elasticity increases from 0.028 to 0.063 , which confirms the downward biasness of our previous estimates. ${ }^{36}$ It follows that Lester's range of pay is about 40.6 per cent of the mean wage. Yet, it could be argued that the

\footnotetext{
${ }^{34}$ Notice that $[0.028 \times 4(34.11 / 21.18)] \times 100$ is equal to 18.0 per cent.

${ }^{35}$ Other instruments used in the literature to control for the endogeneity of profits include e.g. output elasticity, interaction of share of exports with exchange rate and lagged profits.

${ }^{36}$ All coefficients in the first-stage regression are jointly significant at the 1 per cent level. Results are available upon request.
} 
instruments that have been used are inappropriate. To check for this, Sargan's (1964) overidentification test has been applied. The corresponding test statistic is computed as $n R^{\prime 2}$, where $n$ is the number of observations and $R^{\prime 2}$ is the per cent of variation explained in the regression of the residuals from the second-stage equation on the instruments and all exogenous variables in the model. This statistic is distributed $\chi^{2}$ with degrees of freedom equal to the number of overidentifying restrictions (in this case, $\mathrm{df}=2$ ). The results of this test, presented at the bottom of column (2) in Table 9, show that the overidentifying restrictions can not be rejected at the level of 15 per cent. This suggests that our instruments are valid and that our model is well specified.

Finally, in order to analyse whether the remuneration from profits fluctuates along the conditional wage distribution, we ran simultaneous quantile regressions (at the 10th, 50th and 90th percentiles) controlling for the endogeneity of profits. Results from these regressions are reported in columns (3) to (5) of Table 9. They indicate that the elasticity between wages and profits increases from 0.048 at the 10th percentile of the wage distribution to 0.079 at the 90th percentile. To put it differently, it is found that workers at the top end of the wage distribution gain significantly more from firm profits than those at the bottom of the wage distribution.

\subsection{Industry Wage Premia Before and After Controlling for Rent-Sharing}

So far, results have shown that individual hourly wages are significantly and positively related to firm profits-per-employee. In this sub-section, we examine to what extend industry wage differentials are explained by this rent-sharing phenomenon. To do so, we compare the significance, magnitude and dispersion of industry wage premia before and after controlling for the elasticity between wages and (instrumented) profits. In other words, we compare results obtained from a wage equation that does only control for individual and firm characteristics (see equation (1)) with those of an earnings equation that does also control for firm profits-per-capita (see equation (10)). 
Table 10: Industry Wage Premia Before and After Controlling for Rent-Sharing, 1995

\begin{tabular}{lcc}
\hline Industry (NACE two-digit): & $\begin{array}{c}\text { Not controlling } \\
\text { for profits }\end{array}$ & $\begin{array}{c}\text { Controlling for } \\
\text { (instrumented) profits }\end{array}$
\end{tabular}

\begin{tabular}{lcc}
\hline Other mining and quarrying (14) & $(1)$ & 0.011 \\
$(2)$ & $(0.018)$ & -0.058
\end{tabular}

Manufacture of food products and beverages (15)

$(0.018) \quad(0.038)$

$0.012 * \quad-0.026$

Manufacture of tobacco products (16)

$(0.007) \quad(0.016)$

$0.031-0.017$

$(0.019) \quad(0.030)$

Manufacture of textiles (17)

$-0.099 *-0.109 * *$

$\begin{array}{cc}(0.008) & (0.016) \\ -0.125 * * & -0.098 * *\end{array}$

Manufacture of wearing apparel; dressing and dyeing of fur (18)

$(0.015) \quad(0.026)$

Tanning and dressing of leather; manufacture of luggage, handbags, saddlery, harness and footwear (19)

Manufacture of wood and products of wood and cork, except

furniture; manufacture of articles of straw and plaiting materials (20)

Manufacture of pulp, paper and paper products (21)

Publishing, printing and reproduction of recorded media (22)

0.012

$0.054^{\circ}$

$(0.023) \quad(0.029)$

$-0.048^{* *} \quad-0.035^{\circ}$

$(0.009) \quad(0.019)$

$0.073 * * \quad 0.048$

$(0.010) \quad(0.034)$

$0.096 * * \quad 0.089 * *$

$(0.009) \quad(0.020)$

$0.227 * * \quad 0.156 * *$

Manufacture of coke, refined petroleum products and nuclear fuel (23)

Manufacture of chemicals and chemical products (24)

$(0.018) \quad(0.058)$

$0.104 * * \quad 0.037 * *$

$(0.004) \quad(0.012)$

$0.020 * * \quad 0.007$

$(0.008) \quad(0.018)$

$0.020 * * \quad-0.006$

$(0.007) \quad(0.015)$

$0.081 * * \quad 0.058 * *$

$(0.007) \quad(0.016)$

$0.017 * * \quad 0.019$

$(0.007) \quad(0.017)$

$-0.052 * * \quad-0.043 *$

$(0.005) \quad(0.020)$

Manufacture of office machinery and computers (30)

Manufacture of electrical machinery and apparatus n.e.c. (31)

Manufacture of radio, television and communications equipment and apparatus (32)

Manufacture of medical, precision and optical instruments, watches and clocks (33)

Manufacture of motor vehicles, trailers and semi-trailers (34)

Manufacture of other transport equipment (35)

Manufacture of furniture; manufacturing n.e.c. (36)

Recycling (37)

Electricity, gas, steam and hot water supply (40)

Construction (45)

Sale, maintenance and repair of motor vehicles and motorcycles; retail sale of automotive fuel (50)

Wholesale trade and commission trade, except of motor vehicles and motorcycles (51)

$\begin{array}{cc}/ & / \\ 0.003 & 0.060^{\circ} \\ (0.008) & (0.035) \\ 0.013^{\circ} & 0.020 \\ (0.008) & (0.028) \\ 0.061^{* *} & 0.043 \\ (0.016) & (0.051) \\ -0.029 * * & -0.021 \\ (0.006) & (0.018) \\ -0.011 & 0.002 \\ (0.009) & (0.019) \\ -0.081 * * & -0.050^{*} \\ (0.009) & (0.020) \\ -0.052^{* *} & 0.051 * \\ (0.018) & (0.023) \\ 0.396^{* *} & 0.211^{* *} \\ (0.030) & (0.017) \\ -0.060^{* *} & -0.004 \\ (0.007) & (0.015) \\ 0.008 & -0.023 \\ (0.010) & (0.023) \\ 0.010^{*} & -0.008 \\ (0.004) & (0.011)\end{array}$


Retail trade, except of motor vehicles and motorcycles; repair of personal and household goods (52)

\begin{tabular}{cc}
$-0.084 * *$ & $-0.049 * *$ \\
$(0.010)$ & $(0.019)$ \\
$-0.082^{* *}$ & -0.043 \\
$(0.017)$ & $(0.034)$ \\
$-0.066^{* *}$ & -0.050 \\
$(0.011)$ & $(0.041)$ \\
$0.214^{* *}$ & $0.150^{*}$ \\
$(0.032)$ & $(0.060)$ \\
$0.115^{* *}$ & 0.083 \\
$(0.044)$ & $(0.060)$ \\
$0.038^{* *}$ & $0.076^{* *}$ \\
$(0.011)$ & $(0.024)$ \\
$0.332^{* *}$ & $0.268^{* *}$ \\
$(0.033)$ & $(0.089)$ \\
$0.053^{\circ}$ & $-0.064^{\circ}$ \\
$(0.029)$ & $(0.036)$ \\
-0.010 & 0.013 \\
$(0.010)$ & $(0.036)$ \\
$0.101^{* *}$ & $0.073^{*}$ \\
$(0.020)$ & $(0.034)$ \\
0.002 & $0.056^{* *}$ \\
$(0.006)$ & $(0.015)$ \\
\hline 0.697 & 0.697 \\
$555.3 * *$ & $56,392.1 * *$ \\
$80.9 * *$ & $71.1 * *$ \\
$78.9 \%$ & $52.6 \%$ \\
$(30 / 38)$ & $(20 / 38)$ \\
0.521 & 0.366 \\
0.068 & 0.048 \\
& \\
& \\
&
\end{tabular}

Hotels and restaurants (55)

Land transport; transport via pipelines (60)

Water transport (61)

Air transport (62)

Supporting and auxiliary transport activities; activities of travel agencies (63)

Post and telecommunications (64)

Renting of machinery and equipment without operator and of personal and household goods (71)

Computer and related activities (72)

Research and development (73)

Other businesses activities (74)

Adjusted $\mathrm{R}^{2}$ of wage regression

F-test relative to the wage regression

F-test relative to the sectoral dummies

Per cent significant wage differentials at the 10 per cent level

Range of industry wage differentials

0.068

0.048

Correlation coefficient between industry wage differentials estimated

with and without control for profits:

- Pearson

$0.893 * *$

$0.752 * *$

Number of industries

38

Number of observations

34,972

38

34,972

Notes: Industry wage differentials in column (1) and (2) are estimated on the basis of equations (1) and (10) respectively, with dependent variable the ln of individual gross hourly wages including annual bonuses. Standard errors of the industry wage differentials, computed according to Zanchi (1998), are reported between brackets. $* * / * / \circ$ : industry wage differential significant at the 1,5 and $10 \%$, respectively.

Results reported in Table 10 show that substantial wage differentials are still recorded between workers employed in different sectors after controlling for profits. However, the percentage significant industry wage differentials (at the 5 per cent level) decreases from around 75 to 50 per cent. We further note that the hierarchy of sectors in terms of wages remains almost unchanged. Indeed, Pearson and Spearman correlation coefficients between the wage differentials estimated with and without control for profits stands at between 0.75 and 0.89. Among the best-paying sectors we still find the post and telecommunications sector; the electricity, gas, steam and hot water supply sector; the manufacture of coke, refined petroleum products and nuclear fuel industry; and the water transport sector. However, the wage premium in these sectors decreases by between 19 and 47 per cent when controlling for 
profits. Furthermore it is still in the traditional sectors (e.g. hotels and restaurants, the textile industry and retailing), that wages are lowest. Yet, the estimated wage disadvantage of working in these sectors is substantially reduced when controlling for profits. Last but not least, we find that the dispersion in industry wage differentials (the WASD) drops by almost one-third when profits are taken into account. These findings offer some clear evidence for the fact that rent-sharing accounts for a large fraction of the observed industry wage differentials. $^{37}$

\section{Conclusion}

In this paper, we wanted to shed some light on the magnitude, stability and causes of interindustry wage differentials in Belgium. To do so, four central questions have been addressed: i) Are sectoral differences in pay a temporary phenomenon or do they persist over time ?, ii) Do they derive from sectoral differences in the unobserved quality of the labour force ?, iii) To what extent are they shaped by the sectors' 'ability to pay', i.e. profits ?, iii) What is the contribution of rent-sharing to the observed industry wage differentials ? These questions have been investigated on the basis of a unique matched employer-employee data set covering the period 1995-2002. This data set derives from the combination of the Structure of Earnings Survey and the Structure of Business Survey. The former contains detailed information on firm characteristics (e.g. sector of activity, size of the firm, and level of wage bargaining) and on individual workers (e.g. gross hourly wages, bonuses, age, education, sex, and occupation). The latter provides firm- and sector-level information on financial variables (e.g. gross operating surplus, value added, and value of production).

Our findings show the existence of substantial and persistent wage differentials among workers having the same observed characteristics and working conditions, employed in different sectors. The best paying industry over the period 1995-2002 is the electricity, gas, steam and hot water supply sector. Depending on the period considered, the average worker in this sector earns ceteris paribus between 27 and 31 per cent more than the average worker in the whole economy. At the top of the conditional wage distribution, we also find the manufacture of coke, refined petroleum products and nuclear fuel industry (between +20 and 34 per cent), the air transport sector (between +12 and 19 per cent), the manufacture of

\footnotetext{
${ }^{37}$ Results at the Nace three-digit level, reported in the Appendix 17, reinforce this conclusion.
} 
chemicals and chemical products industry (between +11 and 12 per cent), and financial intermediaries, except insurance and pension funding (between +6 and 13 per cent). The hotel and restaurant sector is at the very bottom of the wage scale: the average worker's wage there is ceteris paribus between 11 and 14 per cent lower than that of the average worker in the economy. At the bottom of the scale, we also find the manufacture of wearing apparel, dressing and dyeing of fur (between -11 and -13 per cent), retail trade (between -7 and -12 per cent), the manufacture of furniture (between -8 and -10 per cent), and the manufacture of textiles (between -4 and -8 per cent).

Regarding the dispersion of inter-industry wage differentials, we find that Belgium occupies a middle position among the industrialised countries. The scale of the latter is indeed lower than in the Anglo-Saxon countries and higher than in the Scandinavian countries. Yet, it appears that the dispersion of wages across sectors in Belgium has steadily decreased between 1995 and 2002. The explanation for this evolution is still unsettled. However, it could be related to the European integration process or the deregulation of certain industries.

Industry wage differentials may of course derive from the fact that the unobserved quality of the labour force is not randomly distributed across sectors. In other words, high-paying industries might simply be those in which the unobserved quality of the labour force is the highest. This potential explanation has been tested with Martins' (2004) methodology. The latter implies to verify, on the basis of quantile regressions, whether sectors with high average premia have even higher premia among high wage workers. Empirical results show that the unobserved ability hypothesis may not be rejected. However, its contribution to the observed industry wage differentials appears to be limited. The role of non-competitive forces should therefore not be neglected.

The most natural non-competitive explanation for the existence of industry wage premia is that they result from inter-sectoral variations in 'ability to pay', i.e. profits. This explanation has been tested using simple correlation coefficients and cross-sectional regressions. Results show that industry wage premia are significantly and positively correlated with industry profits, in all periods, both at the Nace two- and three digit level. They thus support the hypothesis that that industry wage premia derive at least partly from the heterogeneity in sectoral profits. Yet, they are consistent with several explanations going beyond the standard competitive model, including efficiency wage theory and rent-sharing. 
The magnitude of rent-sharing in the Belgian private sector and its contribution to the observed industry wage differentials has been examined in the last section of this paper. Empirical results show first that individual gross hourly wages are significantly and positively related to firm profits-per-employee, even after controlling for group effects in the residuals, individual and firm characteristics, industry wage differentials, and endogeneity of profits. The instrumented wage-profit elasticity estimated at the mean is equal to 0.063 . However, workers at the top end of the wage distribution are found to gain significantly more from profits than those at the bottom of the wage distribution. Further results show that substantial wage differentials are still recorded between workers employed in different sectors after controlling for rent-sharing. However, the proportion of significant industry wage premia decreases from around 75 to 50 per cent. We also find that the dispersion in industry wage differentials drops by almost one-third when profits are taken into account. These findings suggest that rent-sharing accounts for a large fraction of the industry wage differentials.

Future research in this area should rely on matched employer-employee panel data so as to control for the time-invariant unobserved characteristics of the workers. Longitudinal data would in particular allow to measure how much of the cross-sectional inter-industry wage differentials is removed by the introduction of fixed effects. Unfortunately, at present these data do not exist for Belgium. 


\section{REFERENCES}

Abowd J.M. and Lemieux T. (1993), "The Effect of Product Market Competition on Collective Bargaining Agreements: The Case of Foreign Competition in Canada", Quarterly Journal of Economics, Vol. 108, No. 4, 983-1014.

Abowd J.M., Kramarz F., and Margolis D.N. (1999), "High Wage Workers and High Wage Firms." Econometrica, Vol. 67, No. 2, 251-333.

Arai M. (2003), “Wages, Profits and, Capital Intensity: Evidence from Matched Worker-Firm Data”, Journal of Labour Economics, Vol. 21, No. 3, 593-618.

Araï M. (1994), “Compensating wage differentials versus efficiency wages : an empirical study of job autonomy and wages", Industrial Relations, Vol. 33, No. 2, 249-62.

Araï M., Ballot G., and Skalli A. (1996), "Différentiels intersectoriels de salaire et caractéristiques des employeurs en France”, Economie et Statistique, No. 299, 37-58.

Arai M. (2003), "Wages, Profits, and Capital Intensity: Evidence from Matched Worker-Firm Data", Journal of Labor Economics, Vol. 21, No. 3, 593-618.

Benito A. (2000), "Inter-Industry Wage Differentials in Great Britain", Oxford Bulletin of Economics and Statictics, Vol. 62, No. 0, 727-46.

Björklund A., Bratsberg B., Eriksson T., Jäntti M., and Raaum O. (2004), “Inter-Industry Wage Differentials and Unobserved Ability: Siblings Evidence from Five Countries”, IZA Discussion Paper No. 1080 (forthcoming in Industrial Relations).

Blanchflower D.G., Oswald A.J., and Sanfey P. (1996), “Wages, Profits and Rent-Sharing”, Quarterly Journal of Economics, Vol. 111, No. 1, 227-51.

Booth A. (1995), The Economics of the Trade Union, Cambridge University Press: Cambridge.

Carruth A, Collier W and Dickerson A. (2004), "Inter-industry Wage Differences and Individual Heterogeneity", Oxford Bulletin of Economics and Statistics, Vol. 55, No. 5, 811-46.

Christofides L.N. and Oswald A.J. (1992), "Real Wage Determination and Rent-Sharing in Collective Bargaining Agreements”, Quarterly Journal of Economics, Vol. 107, No. 3, 985-1002.

Demunter C. (2000), "Structure and Distribution of Earnings Survey: Analysis 1995”, Statistics Belgium Working Paper, Statistics Belgium.

Dickens W.T. and Katz L.F. (1987), "Inter-Industry Wage Differences and Industry Characteristics”, in Lang K. and Leonard J. (eds.), Unemployment and the Structure of Labour Market, Basil Blackwell: Oxford.

Docquier F., Laurent S. and Perelman S. (1999), "Capital humain, emploi et revenus du travail : Belgique, 1992”, Cahiers Economiques de Bruxelles, Vol. 161, 77-103.

Edin P.-A. and Zetterberg J. (1992), "Interindustry Wage Differentials: Evidence from Sweden and a Comparison with the USA", American Economic Review, Vol. 82, No. 5, 1341-49.

Fakhfakh F. and FitzRoy F. (2004), "Basic Wages and Firm Characteristics: Rent-sharing in French Manufacturing”, Labour, Vol. 18, No.4, 615-31.

Ferro-Luzzi G. (1994), "Inter-Industry Wage Differentials in Switzerland", Swiss Journal of Economics and Statistics, Vol. 130, No. 3, 421-43.

Gannon B., Plasman R., Rycx F., and Tojerow I. (2005), "Inter-Industry Wage Differentials and the Gender Wage Gap: Evidence from European Countries", IZA Discussion Paper No. 1563, April.

Genre V., Momferatou D. and Mourre Gilles (2005), «Wage Diversity in the Euro Area, an Overview of Labour Cost Differentials across Industries”, ECB Occasional Paper, No. 24.

Gibbons R. and Katz L.F. (1992), “Does Unmeasured Ability Explain Interindustry Wage Differentials ?”, Review of Economic Studies, Vol. 59, No. 3, 515-35.

Goos M. and Konings J. (2001), "Does Rent-Sharing Exist in Belgium? An Empirical Analysis Using Firm Level Data", Reflets et Perspectives de la vie économique, Vol. XL No. 1/2, 65-79. 
Goux D. and Maurin E. (1999), "Persistence of Inter-Industry Wage Differentials: A Reexamination Using Matched Worker-Firm Panel Data", Journal of Labor Economics, Vol. 17, No. 3, 492-533.

Greenwald B.C. (1983), "A General Analysis of Bias in the Estimated Standard Errors of Least Square Coefficients", Journal of Econometrics, Vol. 22, No. 3, 323-38.

Groshen E.L. and Krueger A.B. (1990), "The Structure of Supervision and Pay in Hospitals", Industrial and Labor Relations Review, Special Issue Vol. 43, No. 3, 134-46.

Gujarati D. (1995), Basic econometrics, McGraw-Hill International, Singapore.

Gürtzgen N. (2005), "Rent-sharing: Does the Bargaining Regime Make a Difference? Theory and Empirical Evidence", ZEW Discussion Paper No. 05-15.

Haisken-DeNew J.P. and Schmidt C.M. (1997), "Interindustry and Interregion Differentials: Mechanics and Interpretation”, Review of Economics and Statistics, Vol. 79, No. 3, 516-21.

Harris M. and Holmström B. (1982), “A Theory of Wage Dynamics”, Review of Economic Studies, Vol. 49 No. 3, 315-33.

Hartog J., Van Opstal R., and Teulings C.N. (1997), "Inter-Industry Wage Differentials and Tenure Effects in the Netherlands and the U.S.” De Economist, Vol. 145, No. 1, 91-9.

Hartog J., Pereira P.T., and Vieira J.A.C. (2000), "Inter-Industry Wage Dispersion in Portugal”, Empirica, Vol. 27, No. 4, 353-64.

Helwege J. (1992), "Sectoral Shifts and Interindustry Wage Differentials”, Journal of Labor Economics, Vol. 10, No. 1, 55-84.

Hildreth A.K.G. and Oswald A.J. (1997), "Rent-Sharing and Wages: Evidence from Company and Establishment Panels", Journal of Labor Economics, Vol. 15, No. 2, 318-337.

Holmlund B. and Zetterberg J. (1991), "Insider Effects in Wage Determination: Evidence from Five Countries", European Economic Review, Vol. 35, No.5, 1009-34.

Jepsen M. (2001), "Evaluation des différentiels salariaux en Belgique: homme-femme et temps partiel-temps plein", Reflets et Perspectives de la vie économique, Vol. 40, No. 1-2, 51-63.

Jepsen M., O’Dorchai S., Plasman R. and Rycx F. (2005), “The Wage Penalty Induced by Part-time Work: The Case of Belgium”, Brussels Economic Review, Vol. 48, No. 1/2, 73-94.

Kahn L.M. (1998), "Collective Bargaining and Interindustry Wage Structure: International Evidence", Economica, Vol. 65, No. 260, 507-34.

Katz L.F. and Summers L.H. (1989), "Industry Rents: Evidence and Implications", Brookings Papers on Economic Activity: Macroeconomics, Vol. 1989, 209-75.

Konings J. (2005), “Worden vrouwen gediscrimineerd op de arbeidsmarkt? Een micro-econometrische analyse voor Begië”, Leuvense Economische Standpunten, No. 108, KULeuven.

Kouwenberg J. and van Opstal R. (1999), "Inter-industry Wage Differentials: Evidence from Micro Data", $C P B$ Report 1999/3, Quarterly Review of CPB Netherlands Bureau for Economic Policy Analysis.

Krueger A.B. and Summers L.H. (1987), "Reflection on the Inter-Industry Wage Structure", in Lang K. and Leonard J. (eds), Unemployment and the Structure of Labour Markets, Basil Blackwell: Oxford.

Krueger A.B. and Summers L.H. (1988), "Efficiency Wages and Inter-Industry Wage Structure", Econometrica, Vol. 56, No. 2, 259-93.

Lallemand T., Plasman R. and Rycx F. (2005), "Why Do Large Firms Pay Higher Wages? Evidence from Matched Worker-Firm Data”, International Journal of Manpower, Vol. 26, No. 7/8, 705-23.

Laurent S. (2000), "Capital humain, emploi et salaire en Belgique et dans ses régions", Rapport préparatoire du $14^{\text {ième }}$ Congrès des Economistes Belges de Langue Française, Commission 4: Capital humain et croissance régionale, CIFoP.

Lester R.A. (1952), “A Range Theory of Wage Differentials”, Industrial and Labour Relations Review, Vol. 5, No. 4, 483-500. 
Lindbeck A. and Snower D.J. (1990), "Interindustry Wage Structure and the Power of Incumbent Workers", in Brunetta R. and Dell' Aringa C. (eds.), Labour Relations and Economic Performance, London: Macmillan, 378-90.

Lucifora C. (1993), "Inter-Industry and Occupational Wage Differentials in Italy", Applied Economics, Vol. 25, No. 8, 1113-24.

Manning A. (1987), “An Integration of Trade Union Models in a Sequential Bargaining Framework”, Economic Journal, Vol. 97, No. 385, 121-39.

Margolis D.N. and Salvanes K.G. (2001), “Do Firms Really Share Rents with their Workers?”, CREST Working Paper, No. 2001-16.

Martins P.S. (2003), "Rent Sharing before and after the Wage Bill”, Mimeo, Department of Economics, University of Warwick.

Martins P.S. (2004), "Industry Wage Premia: Evidence from the Wage Distribution”, Economics Letters, Vol. 83, 157-163.

McDonald I. and Solow R. (1981), "Wage Bargaining and Employment”, American Economic Review, Vol. 74, No. 5, 896-908.

Moulton B.R. (1990), “An Illustration of a Pitfall in Estimating the Effects of Aggregate Variables on Micro Units”, Review of Economics and Statistics, Vol. 72, No. 2, 334-38.

Murphy K. and Topel R. (1990), "Efficiency Wages Reconsidered: theory and evidence." In Weiss Y. and Fishelson G. (eds.), Advances in the Theory and Measurement of Unemployment, London: Macmillan, 20440.

Murphy K. and Welch F. (1990), “Empirical age-earnings profiles”, Journal of Labor Economics, Vol. 8, No. 2, 202-29.

Nekby L. (2003), "Gender Differences in Rent Sharing and Its Implications for the Gender Wage Gap, Evidence from Sweden”, Economics Letters, Vol. 81, No. 3, 403-410.

Nickell S. (1999), "Product Markets and Labour Markets”, Labour Economics, Vol. 6, No. 1, 1-20.

Nickell S. and Andrews M. (1983), "Unions, Real Wages and Employment in Britain 1951-79", Oxford Economic Paper, Vol. 35, No. supplement, 183-206.

OECD (1997), Employment Outlook, Paris, OECD.

OECD (2004), Employment Outlook, Paris, OECD.

Over M., Jolliffe D. and Foster A.D. (1996), "Huber Correction for Two Stage Squared Estimation", Stata Technical Bulletin, Vol. January 1996, 24-25.

Pencavel J. (1991), Labour Markets under Trade Unionism. Employment, Wages and Hours. Blackwell publishers: Cambridge, MA.

Plasman A., Plasman R., Rusinek M. and Rycx, F. (2001), "Indicators on Gender Pay Equality," Cahiers Economiques de Bruxelles, Vol. 45, No. 2, 11-40.

Plasman R., Rusinek M., and Rycx F. (2006), "Wages and the Bargaining Regime under Multi-level Bargaining: Belgium, Denmark and Spain”, IZA Discussion Paper No. 1990 (forthcoming in European Journal of Industrial Relations).

Reilly K.T. and Zanchi L. (2003), “Industry Wage Differentials: How many, Big and Significant?” International Journal of Manpower, Vol. 24, No. 4, 367-98.

Rycx F. (2002), "Inter-Industry Wage Differentials: Evidence from Belgium in a Cross-National Perspective”, De Economist, Vol. 150, No. 5, 555-68.

Rycx F. (2003), "Industry Wage Differentials and the Bargaining Regime in a Corporatist Country", International Journal of Manpower, Vol. 24, No. 4, 347-66.

Rycx F. and Tojerow I. (2002), "Inter-Industry Wage Differentials and the Gender Wage Gap in Belgium", Cahiers Economiques de Bruxelles, Vol. 45, No. 2, 119-41. 
Rycx F. and Tojerow I. (2004), "Rent Sharing and the Gender Wage Gap in Belgium", International Journal of Manpower, Vol. 25, No. 3/4,. 279-99.

Sargan J.D. (1964), "Wages and Prices in the United Kingdom: a Study in Econometric Methodology", in Hart, P.E., Mills, G. and Whitaker, J.K. (eds) Econometric Analysis for National Economic Planning, Butterworths: London.

Shapiro, C. and Stiglitz, J.E. (1984), "Equilibrium Unemployment as a Worker Discipline Device", American Economic Review, Vol. 74, No. 3, 433-44.

Slichter S.H. (1950), "Notes on the Structure of Wages", Review of Economics and Statistics, Vol. 32, 80-91.

Stiglitz J. (1974), “Alternative Theories of Wage Determination in LDC'S: The Labor Turnover Model”, Quarterly Journal of Economics, Vol. 88, No. 2, 194-227.

StataCorp (1999), Stata Statistical Software: Release 6.0, College Station, Texas, Stata Corporation.

Stiglitz J. (1974), “Alternative Theories of Wage Determination in LDC'S : The Labour Turnover model”, Quarterly Journal of Economics, Vol. 88, No. 2, 194-227.

Teal F. (1996), “The Size and Sources of Economic Rents in a Developing Country Manufacturing Labour Market”, Economic Journal, Vol. 106, No. 437, 963-76.

Teulings C.N. and Hartog J. (1998), Corporatism or Competition? Labour Contracts, Institutions and Wage Structures in International Comparison. Cambridge: Cambridge University Press.

Thaler R.H. (1989), “Anomalies: Interindustry Wage Differentials”, Journal of Economic Perspectives, Vol. 3, No. 2, 181-93.

Vainiomäki J. and Laaksonen S. (1995), "Interindustry Wage Differentials in Finland: Evidence from Longitudinal Census Data for 1975-85”, Labour Economics, Vol. 2, No. 2, 161-73.

Vannetelbosch V. (1996), "Testing between Alternative Wage-employment Bargaining Models using Belgian Aggregate Data", Labour Economics, Vol. 3, No. 1, 43-64.

Van Reenen J. (1996), "The Creation and Capture of Rents: Wages and Innovation in a Panel of U.K. Companies," Quarterly Journal of Economics, Vol. 111, No. 1, 195-226.

Walsh F. (1999), “A Multisector Model of Efficiency Wages”, Journal of Labor Economics, Vol. 17, No. 2, 351-376.

White H. (1980), “A Heteroscedasticity-Consistent Covariance Matrix Estimator and a Direct Test for Heteroscedasticity", Econometrica, Vol. 48, 817-38.

Winter-Ebmer R. and Zweimueller J. (1999), "Firm-size Wage Differentials in Switzerland: Evidence from Jobchangers", American Economic Review Papers and Proceedings, Vol. 89, 89-93.

Wolf E. (2002), “Lower Wage Rates for Fewer Hours? A Simultaneous Wage-Hours Model for Germany”, Labour Economics, Vol. 9, No. 5, 643-63.

Wooldridge J.M. (2002), Econometric Analysis of Cross Section and Panel Data. MIT Press: Cambridge, MA.

Zanchi L. (1992), "Inter-Industry Wage Structure: Empirical Evidence for Germany and a Comparison with the U.S. and Sweden”, European University Institute Working Paper ECO No. 92/76, Florence, Italy.

Zanchi L. (1998), "Interindustry Wage Differentials in Dummy Variable Models”, Economics Letters, Vol. 60, 297-301.

Zweimuller J. and Barth E. (1994), "Bargaining Structure, Wage Determination and Wage Dispersion in 6 OECD Countries", Kyklos, Vol. 47, No. 1, 81-93. 
APPENDIX 1: Description and Means (S.D.) of Selected Variables (SES 1995, 1999, 2002).

\begin{tabular}{|c|c|c|c|}
\hline & SES 1995 & SES 1999 & SES 2002 \\
\hline $\begin{array}{l}\text { Gross hourly wage, including bonuses: (in EUR) includes overtime } \\
\text { paid, premiums for shift work, night work and/or weekend work } \\
\text { and bonuses (i.e. irregular payments which do not occur during } \\
\text { each pay period, such as pay for holiday, } 13^{\text {th }} \text { month, profit } \\
\text { sharing, etc.). }\end{array}$ & $\begin{array}{l}14.04 \\
(7.3)\end{array}$ & / & $\begin{array}{l}15.5 \\
(8.6)\end{array}$ \\
\hline $\begin{array}{l}\text { Gross hourly wage, excluding bonuses: (in EUR) includes overtime } \\
\text { paid, premiums for shift work, night work and/or weekend work. } \\
\text { Education: }\end{array}$ & $\begin{array}{l}12.32 \\
(5.7)\end{array}$ & $\begin{array}{l}13.12 \\
(6.6)\end{array}$ & $\begin{array}{l}13.74 \\
(6.5)\end{array}$ \\
\hline Primary or no degree & 9.7 & 8.5 & 8.1 \\
\hline Lower secondary & 24.3 & 29.6 & 28.0 \\
\hline General upper secondary & 18.4 & 21.0 & 19.2 \\
\hline Technical/Artistic/Prof. upper secondary & 24.9 & 17.4 & 19.7 \\
\hline Higher non-university short type, higher artistic training & 13.9 & 14.8 & 15.3 \\
\hline University and non-university higher education, long type & 8.4 & 8.3 & 8.9 \\
\hline Post-graduate & 0.5 & 0.5 & 0.6 \\
\hline $\begin{array}{l}\text { Prior potential experience: (years), experience (potentially) } \\
\text { accumulated on the labour market before the last job. It has be } \\
\text { computed as follows: age }-6-\text { years of education - seniority. }\end{array}$ & $\begin{array}{l}9.5 \\
(8.5)\end{array}$ & $\begin{array}{l}10.9 \\
(8.8)\end{array}$ & $\begin{array}{l}11.5 \\
(9.7)\end{array}$ \\
\hline Seniority in the current company: (years). & $\begin{array}{c}9.9 \\
(9.0)\end{array}$ & $\begin{array}{c}8.9 \\
(9.3)\end{array}$ & $\begin{array}{l}8.5 \\
(9.1)\end{array}$ \\
\hline $\begin{array}{l}\text { Hours: number of hours paid in the reference period, including } \\
\text { overtime paid. }\end{array}$ & $\begin{array}{l}160.5 \\
(26.5)\end{array}$ & $\begin{array}{l}147.7 \\
(40.6)\end{array}$ & $\begin{array}{l}153.8 \\
(41.4)\end{array}$ \\
\hline Female (yes) & 31.4 & 30.3 & 32.0 \\
\hline Overtime paid (yes) & 7.3 & 3.8 & 2.1 \\
\hline Bonuses for shift work, night work and/or weekend work (yes) & 15.1 & 14.9 & 14.1 \\
\hline Supervises the work of other workers (yes) & 16.3 & / & / \\
\hline Type of contract: & & & \\
\hline Unlimited-term employment contract & 97.0 & 95.0 & 95.7 \\
\hline Limited-term employment contract & 2.4 & 3.7 & 3.4 \\
\hline Apprentice/Trainee contract & 0.1 & 0.2 & 0.2 \\
\hline Other & 0.4 & 1.2 & 0.7 \\
\hline Occupation: & & & \\
\hline Corporate managers (P12) & 6.3 & 3.1 & 2.7 \\
\hline Managers of small enterprises (P13) & 0.1 & 0.7 & 0.4 \\
\hline $\begin{array}{l}\text { Physical, mathematic and engineer science professionals } \\
\text { (P21) }\end{array}$ & 3.7 & 4.4 & 4.7 \\
\hline Life science and health professionals (P22) & 0.3 & 0.4 & 0.3 \\
\hline Teaching professionals (P23) & 0.0 & 0.0 & 0.0 \\
\hline Other professionals $(\mathrm{P} 24)$ & 1.8 & 4.7 & 6.0 \\
\hline Physical and engineer science associate professionals (P31) & 10.0 & 4.5 & 4.3 \\
\hline Life science and health associate professionals (P32) & 0.2 & 0.3 & 0.4 \\
\hline Teaching associate professionals (P33) & 0.0 & / & 0.0 \\
\hline Other associate professionals (P34) & 4.8 & 2.7 & 3.5 \\
\hline Office clerks (P41) & 18.8 & 17.9 & 17.1 \\
\hline Customer services clerks (P42) & 1.3 & 2.4 & 3.0 \\
\hline Personal and protective services workers (P51) & 3.2 & 4.4 & 4.9 \\
\hline Models, salespersons and demonstrators (P52) & 7.4 & 5.8 & 6.1 \\
\hline Extraction and building trading workers (P71) & 4.3 & 5.8 & 5.5 \\
\hline Metal, machinery and related trades workers (P72) & 8.6 & 7.8 & 7.9 \\
\hline Precision, handicraft, printing workers (P73) & 1.5 & 2.5 & 1.3 \\
\hline Other craft and related trades workers (P74) & 4.5 & 5.9 & 5.9 \\
\hline Stationary plant and related operators (P81) & 2.4 & 3.4 & 3.4 \\
\hline Machine operators and assemblers (P82) & 5.0 & 8.9 & 7.5 \\
\hline Drivers and mobile plant operators (P83) & 4.6 & 4.5 & 4.7 \\
\hline Sales and services elementary occupations (P91) & 3.8 & 4.1 & 4.0 \\
\hline
\end{tabular}


transport (P93)

Size of the establishment: number of workers.

Region: geographic location of the establishment.

Brussels

Wallonia

Flanders

Level of wage bargaining:

Collective agreement only at the national and/or sectoral level

Collective agreement at the company level Other

Number of observations

Notes: The descriptive statistics refer to the weighted sample. Descriptive statisti affiliation of the workers are available on request.

$\begin{array}{lll}7.3 & 5.6 & 6.2\end{array}$

$501.8 \quad 705.3 \quad 651.6$

$(1,133.8) \quad(1,857.0) \quad(1,661.5)$

$\begin{array}{lll}17.6 & 22.7 & 16.4\end{array}$

$\begin{array}{lll}19.4 & 17.9 & 21.5\end{array}$

$63.0 \quad 59.4 \quad 62.1$

$\begin{array}{lll}51.7 & 73.5 & 79.2\end{array}$

$\begin{array}{lll}39.4 & 26.5 & 19.9\end{array}$

$\begin{array}{lll}9.0 & / & 1.2\end{array}$

$\begin{array}{lll}67,023 & 108,677 & 102,594\end{array}$


Hours: number of hours paid in the reference period, including overtime paid. 160.2

Bonuses for shift work, night work and/or weekend work (yes) 21.0

$\begin{array}{ll}\text { Supervises the work of other workers (yes) } & 15.6\end{array}$

Type of contract:

$\begin{array}{ll}\text { Unlimited-term employment contract } & 96.8\end{array}$

$\begin{array}{ll}\text { Limited-term employment contract } & 2.8\end{array}$

$\begin{array}{ll}\text { Apprentice/Trainee contract } & 0.1\end{array}$

$\begin{array}{ll}\text { Other } & 0.3\end{array}$

Occupation:

Corporate managers (P12) $\quad 5.5$

Managers of small enterprises (P13) $\quad 0.1$

Physical, mathematic and engineer science professionals (P21) 4.3

$\begin{array}{ll}\text { Life science and health professionals (P22) } & 0.2\end{array}$

$\begin{array}{ll}\text { Teaching professionals (P23) } & 0.0\end{array}$

$\begin{array}{ll}\text { Other professionals (P24) } & 1.7\end{array}$

Physical and engineer science associate professionals (P31) 10.8

$\begin{array}{ll}\text { Life science and health associate professionals (P32) } & 0.3\end{array}$

$\begin{array}{ll}\text { Teaching associate professionals (P33) } & 0.0\end{array}$

Other associate professionals (P34) $\quad 3.0$

$\begin{array}{lr}\text { Office clerks (P41) } & 15.6\end{array}$

$\begin{array}{ll}\text { Customer services clerks (P42) } & 0.8\end{array}$

$\begin{array}{ll}\text { Personal and protective services workers (P51) } & 2.1\end{array}$

Models, salespersons and demonstrators (P52) $\quad 8.4$

Extraction and building trading workers (P71)

Metal, machinery and related trades workers (P72) $\quad 10.4$

$\begin{array}{ll}\text { Precision, handicraft, printing workers (P73) } & 1.7\end{array}$

Other craft and related trades workers (P74) $\quad 5.0$

Stationary plant and related operators (P81) $\quad 3.3$

$\begin{array}{ll}\text { Machine operators and assemblers (P82) } & 7.0\end{array}$

Drivers and mobile plant operators (P83) $\quad 4.6$

Sales and services elementary occupations (P91) $\quad 3.9$

Labourers in mining, construction, manufacturing and transport (P93)

Size of the establishment: number of workers. $\quad 645.5$ 
Region: geographic location of the establishment.

Brussels

66.9

Wallonia

20.4

Flanders

Level of wage bargaining:

Collective agreement only at the national and/or sectoral level

47.1

Collective agreement at the company level

46.3

Other

6.6

\begin{tabular}{ll}
\hline Number of observations & 34,972
\end{tabular}

Notes: The descriptive statistics refer to the weighted sample. Descriptive statistics relative to the sectoral affiliation of the workers are available on request. 


\section{APPENDIX 3: Gross Hourly Wages (Including Bonuses) and Employment Shares for Nace 2-Digit Industries, 1995}

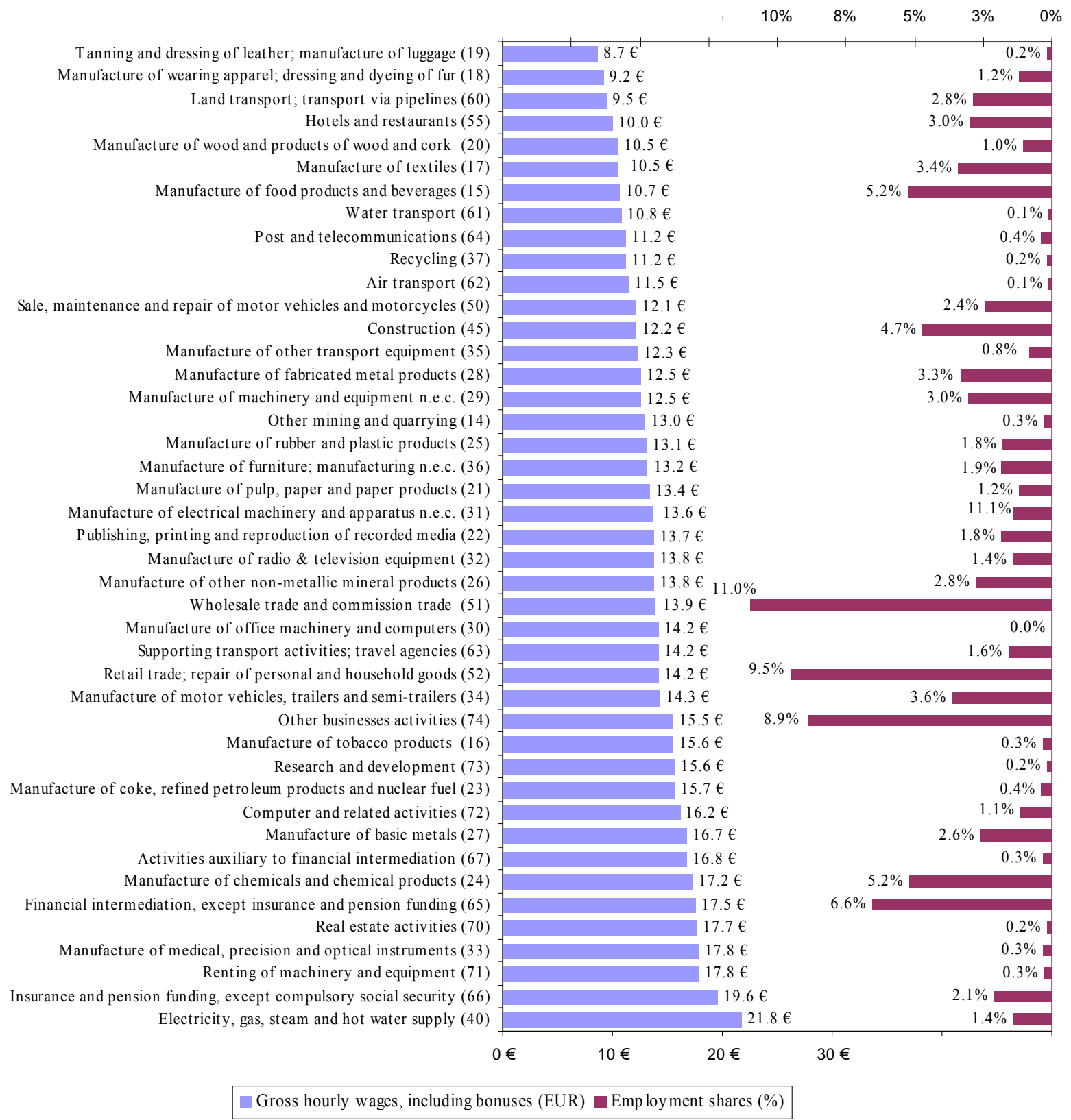

Source: Structure of Earnings Survey, 1995. 
APPENDIX 4: Earnings Equations, Including Annual Bonuses (SES 1995, 2002).

\begin{tabular}{|c|c|c|}
\hline Variables / Data set: & SES 1995 & SES 2002 \\
\hline Intercept & $\begin{array}{l}1.935^{* *} \\
(0.028)\end{array}$ & $\begin{array}{l}2.395 * * \\
(0.024)\end{array}$ \\
\hline \multicolumn{3}{|l|}{ Education: } \\
\hline Primary or no degree & Reference & Reference \\
\hline Lower secondary & $\begin{array}{c}0.054 * * \\
(0.004)\end{array}$ & $\begin{array}{c}0.038^{* *} \\
(0.004)\end{array}$ \\
\hline General upper secondary & $\begin{array}{l}0.150 * * \\
(0.005)\end{array}$ & $\begin{array}{c}0.112 * * \\
(0.005)\end{array}$ \\
\hline Technical/Artistic/Prof. upper secondary & $\begin{array}{c}0.137 * * \\
(0.004)\end{array}$ & $\begin{array}{c}0.116 * * \\
(0.005)\end{array}$ \\
\hline Higher non university short type, higher artistic training & $\begin{array}{c}0.242 * * \\
(0.006)\end{array}$ & $\begin{array}{c}0.204 * * \\
(0.006)\end{array}$ \\
\hline University and non-university higher education, long type & $\begin{array}{c}0.412 * * \\
(0.007)\end{array}$ & $\begin{array}{c}0.352 * * \\
(0.007)\end{array}$ \\
\hline Post-graduate & $\begin{array}{l}0.539 * * \\
(0.021)\end{array}$ & $\begin{array}{l}0.515 * * \\
(0.023)\end{array}$ \\
\hline \multicolumn{3}{|l|}{ Prior experience: } \\
\hline Simple & $\begin{array}{l}0.017 * * \\
(0.001)\end{array}$ & $\begin{array}{c}0.018 * * \\
(0.001)\end{array}$ \\
\hline Squared $/ 10^{2}$ & $\begin{array}{c}-0.038 * * \\
(0.005)\end{array}$ & $\begin{array}{c}-0.048^{* *} \\
(0.004)\end{array}$ \\
\hline Cubed $/ 10^{4}$ & $\begin{array}{l}0.023^{*} \\
(0.010)\end{array}$ & $\begin{array}{l}0.037 * * \\
(0.006)\end{array}$ \\
\hline \multicolumn{3}{|l|}{ Seniority in the company: } \\
\hline Simple & $\begin{array}{c}0.020 * * \\
(0.000)\end{array}$ & $\begin{array}{c}0.020 * * \\
(0.000)\end{array}$ \\
\hline Squared $/ 10^{2}$ & $\begin{array}{c}-0.025 * * \\
(0.001)\end{array}$ & $\begin{array}{c}-0.028 * * \\
(0.001)\end{array}$ \\
\hline Hours paid $(\ln )$ & $\begin{array}{c}0.002 \\
(0.005)\end{array}$ & $\begin{array}{c}-0.046^{* *} \\
(0.004)\end{array}$ \\
\hline Bonus for shift work, night work and/or weekend work (Yes) & $\begin{array}{c}0.058 * * \\
(0.004)\end{array}$ & $\begin{array}{l}0.041 * * \\
(0.003)\end{array}$ \\
\hline Overtime paid (Yes) & $\begin{array}{c}0.018 * * \\
(0.004)\end{array}$ & $\begin{array}{c}0.026 * * \\
(0.005)\end{array}$ \\
\hline \multicolumn{3}{|l|}{ Contract: } \\
\hline Unlimited-term employment contract & Reference & Reference \\
\hline Limited-term employment contract & $\begin{array}{c}-0.046 * * \\
(0.007)\end{array}$ & $\begin{array}{c}-0.092 * * \\
(0.008)\end{array}$ \\
\hline Apprentice/Trainee contract & $\begin{array}{c}-0.700 * * \\
(0.092)\end{array}$ & $\begin{array}{c}-0.329 * * \\
(0.027)\end{array}$ \\
\hline Other employment contract & $\begin{array}{l}-0.047^{\circ} \\
(0.026)\end{array}$ & $\begin{array}{c}-0.055^{* *} * \\
(0.009)\end{array}$ \\
\hline Female (Yes) & $\begin{array}{c}-0.114 * * \\
(0.003)\end{array}$ & $\begin{array}{c}-0.124 * * \\
(0.003)\end{array}$ \\
\hline Occupation (Isco 2 digit) & $\begin{array}{c}\text { Yes } \\
\text { (22 dummies) }\end{array}$ & $\begin{array}{c}\text { Yes } \\
\text { (22 dummies) }\end{array}$ \\
\hline \multicolumn{3}{|l|}{ Region: } \\
\hline Brussels & Reference & Reference \\
\hline Wallonia & $\begin{array}{c}-0.040 * * \\
(0.004)\end{array}$ & $\begin{array}{c}-0.031 * * \\
(0.004)\end{array}$ \\
\hline Flanders & $\begin{array}{c}-0.047 * * \\
(0.003)\end{array}$ & $\begin{array}{l}-0.005 \\
(0.003)\end{array}$ \\
\hline Supervises the work of co-workers (Yes) & $\begin{array}{c}0.113 * * \\
(0.004)\end{array}$ & 1 \\
\hline Size of the establishment $(\ln )$ & $\begin{array}{l}0.030 * * \\
(0.001)\end{array}$ & $\begin{array}{c}0.028 * * \\
(0.001)\end{array}$ \\
\hline Level of wage bargaining & Doforon & \\
\hline
\end{tabular}


Collective agreement at the company level

Other

Industry effects (Nace 3-digit)
Adjusted $\mathrm{R}^{2}$

$0.029 * *$

$(0.003)$

$-0.019 * *$

(0.004)

Yes

(174 dummies) (179 dummies)

0.733

$612.7 * *$

67,023

Number of observations

Notes: White (1980) heteroscedasticity consistent standard errors are reported between brackets. $* * / * /{ }^{\circ}$ : coefficient significant at the 1,5 and $10 \%$, respectively.
$0.053 * *$

$(0.003)$

$0.015^{*}$

(0.008)

Yes

0.662

$490.0 * *$

102,594 
APPENDIX 5: Inter-Industry Wage Differentials and their Dispersion, Excluding Annual Bonuses, Nace 3-Digit (SES 1995, 1999, 2002).

\begin{tabular}{|c|c|c|c|}
\hline Industry (Nace 3-digit) / Data set: & SES 1995 & SES 1999 & SES 2002 \\
\hline Mining and agglomeration of hard coal (101) & / & 1 & $\begin{array}{c}-0.129 * * \\
(0.026)\end{array}$ \\
\hline Extraction and agglomeration of peat (103) & / & / & $\begin{array}{c}-0.174 * * \\
(0.033)\end{array}$ \\
\hline Quarrying of stone (141) & $\begin{array}{c}0.022 \\
(0.015)\end{array}$ & $\begin{array}{c}0.001 \\
(0.018)\end{array}$ & $\begin{array}{c}-0.009 \\
(0.013)\end{array}$ \\
\hline Quarrying of sand and clay (142) & $\begin{array}{c}0.067 * \\
(0.028)\end{array}$ & $\begin{array}{c}0.115 * * \\
(0.020)\end{array}$ & $\begin{array}{l}0.052 * \\
(0.021)\end{array}$ \\
\hline Mining of chemical and fertiliser minerals (143) & $\begin{array}{l}-0.028 \\
(0.082)\end{array}$ & 1 & $\begin{array}{c}-0.057 * * \\
(0.019)\end{array}$ \\
\hline Other mining and quarrying n.e.c. (145) & $\begin{array}{c}-0.163 * * \\
(0.021)\end{array}$ & / & $\begin{array}{l}-0.003 \\
(0.032)\end{array}$ \\
\hline Production, processing and preserving of meat and meat products (151) & $\begin{array}{c}-0.025^{* *} \\
(0.008)\end{array}$ & $\begin{array}{c}-0.020 * * \\
(0.006)\end{array}$ & $\begin{array}{c}-0.036^{* *} \\
(0.006)\end{array}$ \\
\hline Processing and preserving of fish and fish products (152) & $\begin{array}{c}-0.066^{* *} \\
(0.017)\end{array}$ & $\begin{array}{c}-0.043 * * \\
(0.010)\end{array}$ & $\begin{array}{l}-0.002 \\
(0.020)\end{array}$ \\
\hline Processing and preserving of fruit and vegetables (153) & $\begin{array}{c}-0.089 * * \\
(0.011)\end{array}$ & $\begin{array}{c}-0.034 * * \\
(0.010)\end{array}$ & $\begin{array}{c}-0.039 * * \\
(0.009)\end{array}$ \\
\hline Manufacture of vegetable and animal oils and fats (154) & $\begin{array}{c}0.059 * * \\
(0.018)\end{array}$ & $\begin{array}{c}0.133 * * \\
(0.024)\end{array}$ & $\begin{array}{c}0.095 * * \\
(0.020)\end{array}$ \\
\hline Manufacture of dairy products (155) & $\begin{array}{c}0.001 \\
(0.011)\end{array}$ & $\begin{array}{c}-0.032 * * \\
(0.008)\end{array}$ & $\begin{array}{c}-0.029 * * \\
(0.009)\end{array}$ \\
\hline Manufacture of grain mill products, starches and starch products (156) & $\begin{array}{c}0.033 * \\
(0.015)\end{array}$ & $\begin{array}{c}0.067 * * \\
(0.014)\end{array}$ & $\begin{array}{c}0.097 * * \\
(0.016)\end{array}$ \\
\hline Manufacture of prepared animal feeds (157) & $\begin{array}{c}0.016 \\
(0.017)\end{array}$ & $\begin{array}{c}0.022 \\
(0.016)\end{array}$ & $\begin{array}{c}0.011 \\
(0.015)\end{array}$ \\
\hline Manufacture of other food products (158) & $\begin{array}{l}-0.007 \\
(0.011)\end{array}$ & $\begin{array}{c}0.022 * * \\
(0.006)\end{array}$ & $\begin{array}{c}0.004 \\
(0.006)\end{array}$ \\
\hline Manufacture of beverages (159) & $\begin{array}{c}-0.036^{* *} \\
(0.011)\end{array}$ & $\begin{array}{c}-0.022 * * \\
(0.007)\end{array}$ & $\begin{array}{c}-0.002 \\
(0.009)\end{array}$ \\
\hline Manufacture of tobacco product (160) & $\begin{array}{c}0.021 \\
(0.019)\end{array}$ & $\begin{array}{c}0.059^{* *} \\
(0.015)\end{array}$ & $\begin{array}{c}0.046^{* *} \\
(0.013)\end{array}$ \\
\hline Preparation and spinning of textile fibres (171) & $\begin{array}{c}-0.080 * * \\
(0.014)\end{array}$ & $\begin{array}{c}-0.030^{*} \\
(0.012)\end{array}$ & $\begin{array}{c}0.003 \\
(0.013)\end{array}$ \\
\hline Textile weaving (172) & $\begin{array}{c}-0.050 * * \\
(0.011)\end{array}$ & $\begin{array}{l}-0.015 \\
(0.009)\end{array}$ & $\begin{array}{c}0.003 \\
(0.010)\end{array}$ \\
\hline Finishing of textiles (173) & $\begin{array}{c}-0.128 * * \\
(0.027)\end{array}$ & $\begin{array}{c}-0.024 \\
(0.018)\end{array}$ & $\begin{array}{c}-0.045^{* *} \\
(0.010)\end{array}$ \\
\hline Manufacture of made-up textile articles, except apparel (174) & $\begin{array}{c}-0.109 * * \\
(0.011)\end{array}$ & $\begin{array}{c}-0.110 * * \\
(0.013)\end{array}$ & $\begin{array}{c}-0.088 * * \\
(0.015)\end{array}$ \\
\hline Manufacture of other textiles (175) & $\begin{array}{c}-0.028^{* *} \\
(0.010)\end{array}$ & $\begin{array}{c}-0.034 * * \\
(0.006)\end{array}$ & $\begin{array}{c}-0.042^{* *} \\
(0.009)\end{array}$ \\
\hline Manufacture of knitted and crocheted fabrics (176) & $\begin{array}{c}-0.102 \\
(0.065)\end{array}$ & $\begin{array}{l}-0.017 \\
(0.019)\end{array}$ & $\begin{array}{c}-0.034 * \\
(0.016)\end{array}$ \\
\hline Manufacture of knitted and crocheted articles (177) & $\begin{array}{c}-0.250 * * \\
(0.023)\end{array}$ & $\begin{array}{c}-0.079 * * \\
(0.016)\end{array}$ & $\begin{array}{c}-0.112 * * \\
(0.013)\end{array}$ \\
\hline Manufacture of leather clothes (181) & / & $\begin{array}{c}-0.174 * * \\
(0.016)\end{array}$ & / \\
\hline Manufacture of other wearing apparel and accessories (182) & $\begin{array}{c}-0.115^{* *} \\
(0.010)\end{array}$ & $\begin{array}{c}-0.129 * * \\
(0.009)\end{array}$ & $\begin{array}{c}-0.107 * * \\
(0.010)\end{array}$ \\
\hline Dressing and dyeing of fur; manufacture of articles of fur (183) & $\begin{array}{c}-0.165^{* *} \\
(0.027)\end{array}$ & $\begin{array}{c}-0.150 * * \\
(0.022)\end{array}$ & $\begin{array}{c}-0.090 * * \\
(0.031)\end{array}$ \\
\hline Tanning and dressing of leather (191) & $\begin{array}{c}-0.115^{* *} \\
(0.016)\end{array}$ & $\begin{array}{c}-0.171 * * \\
(0.024)\end{array}$ & $\begin{array}{c}-0.136^{* *} \\
(0.030)\end{array}$ \\
\hline $\begin{array}{l}\text { Manufacture of luggage, handbags and the like, saddlery and harness } \\
\text { (192) }\end{array}$ & $\begin{array}{c}0.021 \\
(0.042)\end{array}$ & $\begin{array}{l}-0.019 \\
(0.026)\end{array}$ & $\begin{array}{c}-0.068^{* *} \\
(0.020)\end{array}$ \\
\hline
\end{tabular}


Manufacture of other products of wood; manufacture of articles of cork, straw and plaiting materials (205)

Manufacture of pulp, paper and paperboard (211)

Manufacture of articles of paper and paperboard (212)

Publishing (221)

Printing and service activities related to printing (222)

Reproduction of recorded media (223)

Manufacture of coke oven products (231)

Manufacture of refined petroleum products (232)

Processing of nuclear fuel (233)

Manufacture of basic chemicals (241)

Manufacture of pesticides and other agro-chemical products (242)

Manufacture of paints, varnishes and similar coatings, printing ink and mastics (243)

Manufacture of pharmaceuticals, medicinal chemicals and botanical product (244)

Manufacture of soap and detergents, cleaning and polishing preparations, perfumes and toilet preparations (245)

Manufacture of other chemical products (246)

Manufacture of man-made fibres (247)

Manufacture of rubber products (251)

Manufacture of plastic products (252)

Manufacture of glass and glass products (261)

Manufacture of non-refractory ceramic goods other than for construction purposes; manufacture of refractory ceramic products (262)

Manufacture of ceramic tiles and flags (263)

Manufacture of bricks, tiles and construction products, in baked clay (264)

Manufacture of cement, lime and plaster (265)

Manufacture of articles of concrete, plaster and cement (266)

Cutting, shaping and finishing of stone (267)

\begin{tabular}{|c|c|c|}
\hline-0.036 & $-0.053 * *$ & $-0.111 * *$ \\
\hline$(0.022)$ & $(0.015)$ & $(0.017)$ \\
\hline$-0.037 * *$ & $-0.035^{*}$ & $-0.074 * *$ \\
\hline$(0.013)$ & $(0.014)$ & $(0.010)$ \\
\hline 0.007 & $-0.032 *$ & $-0.031 * *$ \\
\hline$(0.014)$ & $(0.012)$ & $(0.011)$ \\
\hline$-0.043 * *$ & $-0.052 * *$ & $-0.060 * *$ \\
\hline$(0.007)$ & $(0.010)$ & $(0.010)$ \\
\hline-0.009 & -0.018 & $-0.038 * *$ \\
\hline$(0.018)$ & $(0.014)$ & $(0.013)$ \\
\hline$-0.066^{*}$ & $-0.130 * *$ & $-0.051 * *$ \\
\hline$(0.027)$ & $(0.010)$ & $(0.010)$ \\
\hline $0.199 * *$ & $0.114 * *$ & $0.131 * *$ \\
\hline$(0.016)$ & $(0.013)$ & $(0.011)$ \\
\hline 0.018 & $0.044 * *$ & $0.041 * *$ \\
\hline$(0.011)$ & $(0.007)$ & $(0.007)$ \\
\hline 0.027 & 0.006 & $-0.046^{*}$ \\
\hline$(0.017)$ & $(0.010)$ & $(0.018)$ \\
\hline $0.097 * *$ & $0.084 * *$ & $0.115^{* *}$ \\
\hline$(0.008)$ & $(0.008)$ & $(0.007)$ \\
\hline & 0.022 & 0.019 \\
\hline & $(0.027)$ & $(0.040)$ \\
\hline $0.084 *$ & I & $0.157 * *$ \\
\hline$(0.034)$ & & $(0.026)$ \\
\hline $0.267 * *$ & $0.339 * *$ & $0.262 * *$ \\
\hline$(0.020)$ & $(0.017)$ & $(0.018)$ \\
\hline $0.049 *$ & 0.022 & $-0.027^{\circ}$ \\
\hline$(0.024)$ & $(0.020)$ & $(0.016)$ \\
\hline $0.161 * *$ & $0.165^{* *}$ & $0.160 * *$ \\
\hline$(0.005)$ & $(0.006)$ & $(0.006)$ \\
\hline $0.100^{* *}$ & $0.073 * *$ & $0.179 * *$ \\
\hline$(0.031)$ & $(0.024)$ & $(0.028)$ \\
\hline $0.075 * *$ & $0.026^{\circ}$ & $0.040 * *$ \\
\hline$(0.016)$ & $(0.015)$ & $(0.010)$ \\
\hline $0.026^{* *}$ & $0.062 * *$ & $0.064 * *$ \\
\hline$(0.008)$ & $(0.008)$ & $(0.009)$ \\
\hline$-0.026^{*}$ & $-0.019^{\circ}$ & $-0.056^{* *}$ \\
\hline$(0.013)$ & $(0.011)$ & $(0.009)$ \\
\hline $0.107 * *$ & $0.150 * *$ & $0.132 * *$ \\
\hline$(0.013)$ & $(0.012)$ & $(0.010)$ \\
\hline $0.033^{*}$ & $0.057 * *$ & $0.035^{*}$ \\
\hline$(0.015)$ & $(0.012)$ & $(0.016)$ \\
\hline-0.017 & 0.022 & $-0.023^{*}$ \\
\hline$(0.016)$ & $(0.017)$ & $(0.010)$ \\
\hline 0.005 & $0.019 * *$ & $-0.020 * *$ \\
\hline$(0.007)$ & $(0.006)$ & $(0.006)$ \\
\hline 0.013 & $0.022 *$ & $0.040 * *$ \\
\hline$(0.010)$ & $(0.009)$ & $(0.009)$ \\
\hline 0.013 & $-0.026^{*}$ & $-0.032 *$ \\
\hline$(0.018)$ & $(0.012)$ & $(0.014)$ \\
\hline$-0.035 *$ & -0.004 & -0.003 \\
\hline$(0.016)$ & $(0.024)$ & $(0.016)$ \\
\hline-0.021 & $-0.030 * *$ & 0.016 \\
\hline$(0.016)$ & $(0.011)$ & $(0.011)$ \\
\hline $0.172 * *$ & $0.112^{* *}$ & $0.174 * *$ \\
\hline$(0.013)$ & $(0.014)$ & $(0.018)$ \\
\hline $0.020 *$ & $0.017^{*}$ & $0.017^{*}$ \\
\hline$(0.009)$ & $(0.007)$ & $(0.008)$ \\
\hline 0.029 & $0.080 * *$ & 0.011 \\
\hline
\end{tabular}


Manufacture of other non-metallic mineral products (268)

Manufacture of basic iron and steel and of ferro-alloys (ECSC) (271)

Manufacture of tubes (272)

Other first processing of iron and steel and production of non-ECSC

ferro-alloys (273)

Manufacture of basic precious and non-ferrous metals (274)

Casting of metals (275)

Manufacture of structural metal products (281)

Manufacture of tanks, reservoirs and containers of metal; manufacture of central heating radiators and boilers (282)

Manufacture of steam generators, except central heating hot water boilers (283)

Forging, pressing, stamping and roll forming of metal; powder metallurgy (284)

Treatment and coating of metals; general mechanical engineering (285)

Manufacture of cutlery, tools and general hardware (286)

Manufacture of other fabricated metal products (287)

Manufacture of machinery for the production and use of mechanical power, except aircraft, vehicle and cycle engines (291)

Manufacture of other general purpose machinery (292)

Manufacture of agricultural and forestry machinery (293)

Manufacture of machine-tools (294)

Manufacture of other special purpose machinery (295)

Manufacture of weapons and ammunition (296)

Manufacture of domestic appliances n.e.c. (297)

Manufacture of office machinery and computers (300)

Manufacture of electric motors, generators and transformers (311)

Manufacture of electricity distribution and control apparatus (312)

Manufacture of insulated wire and cable (313)

Manufacture of accumulators, primary cells and primary batteries (314)

Manufacture of lighting equipment and electric lamps (315)

Manufacture of electrical equipment n.e.c. (316)

Manufacture of electronic valves and tubes and other electronic components (321)

Manufacture of television and radio transmitters and apparatus for line telephony and line telegraphy (322)

Manufacture of television and radio receivers, sound or video recording

\begin{tabular}{|c|c|c|}
\hline$(0.021)$ & $(0.019)$ & $(0.020)$ \\
\hline $0.088^{*}$ & -0.023 & 0.025 \\
\hline$(0.038)$ & $(0.018)$ & $(0.016)$ \\
\hline 0.011 & $0.071 * *$ & $-0.043 * *$ \\
\hline$(0.013)$ & $(0.012)$ & $(0.010)$ \\
\hline \multirow[t]{2}{*}{ I } & $0.033^{*}$ & $0.047 * *$ \\
\hline & $(0.015)$ & $(0.014)$ \\
\hline $0.046 * *$ & $0.033 *$ & -0.024 \\
\hline$(0.011)$ & $(0.014)$ & $(0.018)$ \\
\hline $0.086^{* *}$ & $0.127 * *$ & $0.069 * *$ \\
\hline$(0.011)$ & $(0.011)$ & $(0.010)$ \\
\hline$-0.031 * *$ & $0.033 * *$ & $-0.030 * *$ \\
\hline$(0.011)$ & $(0.011)$ & $(0.008)$ \\
\hline-0.005 & $-0.053 * *$ & $-0.033 * *$ \\
\hline$(0.009)$ & $(0.006)$ & $(0.005)$ \\
\hline-0.007 & $-0.026^{*}$ & $-0.029 * *$ \\
\hline$(0.011)$ & $(0.011)$ & $(0.009)$ \\
\hline$-0.031^{\circ}$ & $-0.051 *$ & $0.025^{\circ}$ \\
\hline$(0.017)$ & $(0.023)$ & $(0.014)$ \\
\hline $0.064 * *$ & 0.007 & $-0.031 * *$ \\
\hline$(0.018)$ & $(0.011)$ & $(0.012)$ \\
\hline-0.006 & $0.012^{\circ}$ & -0.008 \\
\hline$(0.009)$ & $(0.006)$ & $(0.007)$ \\
\hline-0.008 & -0.015 & 0.017 \\
\hline$(0.013)$ & $(0.010)$ & $(0.012)$ \\
\hline 0.002 & $-0.027 * *$ & $0.020 *$ \\
\hline$(0.013)$ & $(0.010)$ & (0.009) \\
\hline $0.026^{*}$ & $0.047 * *$ & $0.047 * *$ \\
\hline$(0.010)$ & $(0.008)$ & $(0.011)$ \\
\hline$-0.054 * *$ & $-0.035 * *$ & $0.014^{\circ}$ \\
\hline$(0.008)$ & $(0.007)$ & $(0.008)$ \\
\hline$-0.036 * *$ & -0.004 & $0.037 *$ \\
\hline$(0.008)$ & $(0.014)$ & $(0.015)$ \\
\hline$-0.034^{\circ}$ & $-0.033 * *$ & -0.002 \\
\hline$(0.020)$ & $(0.010)$ & $(0.014)$ \\
\hline$-0.058 * *$ & $-0.039 * *$ & $-0.015^{\circ}$ \\
\hline$(0.006)$ & $(0.007)$ & $(0.008)$ \\
\hline $0.100 * *$ & $0.111 * *$ & $0.090 * *$ \\
\hline$(0.010)$ & $(0.015)$ & $(0.019)$ \\
\hline$-0.133 * *$ & $-0.043 * *$ & $-0.039 * *$ \\
\hline$(0.016)$ & $(0.012)$ & $(0.014)$ \\
\hline 0.129 & 0.034 & $-0.057 * *$ \\
\hline$(0.024)$ & $(0.026)$ & $(0.017)$ \\
\hline-0.023 & -0.014 & 0.009 \\
\hline$(0.015)$ & $(0.013)$ & $(0.014)$ \\
\hline 0.011 & $-0.024 *$ & $-0.036 * *$ \\
\hline$(0.012)$ & $(0.011)$ & $(0.009)$ \\
\hline $0.055^{* *}$ & $0.098 * *$ & 0.026 \\
\hline$(0.013)$ & $(0.012)$ & $(0.017)$ \\
\hline $0.049 *$ & $0.065 * *$ & $0.056^{* *}$ \\
\hline$(0.020)$ & $(0.015)$ & $(0.020)$ \\
\hline-0.013 & -0.008 & 0.009 \\
\hline$(0.016)$ & $(0.014)$ & $(0.011)$ \\
\hline$-0.094 * *$ & -0.008 & -0.009 \\
\hline$(0.019)$ & $(0.018)$ & $(0.038)$ \\
\hline 0.021 & $0.062 * *$ & $0.068 * *$ \\
\hline$(0.015)$ & $(0.010)$ & $(0.013)$ \\
\hline $0.054 * *$ & 0.009 & $0.124 * *$ \\
\hline$(0.009)$ & $(0.020)$ & $(0.015)$ \\
\hline$-0.101 * *$ & $-0.040 * *$ & $0.029^{\circ}$ \\
\hline
\end{tabular}


or reproducing apparatus and associated goods (323)

Manufacture of medical and surgical equipment and orthopaedic

appliances (331)

Manufacture of instruments and appliances for measuring, checking,

testing, navigating and other purposes, except industrial process control equipment (332)

Manufacture of industrial process control equipment (333)

(2)

Manufacture of optical instruments and photographic equipment (334)

Manufacture of watches and clocks (335)

Manufacture of motor vehicles (341)

Manufacture of bodies (coachwork) for motor vehicles; manufacture of trailers and semi-trailers (342)

Manufacture of parts and accessories for motor vehicles and their engines (343)

Building and repairing of ships and boats (351)

Manufacture of railway and tramway locomotives and rolling stock (352)

Manufacture of aircraft and spacecraft (353)

Manufacture of motorcycles and bicycles (354)

Manufacture of other transport equipment n.e.c. (355)

Manufacture of furniture (361)

Manufacture of jewellery and related articles (362)

Manufacture of musical instruments (363)

Manufacture of sports goods (364)

Manufacture of games and toys (365)

Miscellaneous manufacturing n.e.c (366)

Recycling of metal waste and scrap (371)

Recycling of non-metal waste and scrap (372)

Production and distribution of electricity (401)

Manufacture of gas; distribution of gaseous fuels through mains (402)

Collection, purification and distribution of water (410)

Site preparation $(451)$

Building of complete constructions or parts thereof; civil engineering (452)

Building installation (453)

Building completion (454)

Renting of construction or demolition equipment with operator (455)

\begin{tabular}{|c|c|c|}
\hline$(0.012)$ & $(0.010)$ & $(0.015)$ \\
\hline $0.065^{*}$ & $-0.036 * *$ & 0.008 \\
\hline$(0.029)$ & $(0.014)$ & $(0.014)$ \\
\hline $0.086 * *$ & $0.094 * *$ & $0.048 * *$ \\
\hline$(0.016)$ & $(0.016)$ & $(0.013)$ \\
\hline 0.008 & $-0.048 * *$ & $-0.077 * *$ \\
\hline$(0.022)$ & $(0.013)$ & $(0.017)$ \\
\hline$-0.167 * *$ & $-0.051 * *$ & $-0.052 *$ \\
\hline$(0.037)$ & $(0.016)$ & $(0.023)$ \\
\hline$-0.107 * *$ & $-0.039 *$ & $-0.050 *$ \\
\hline$(0.023)$ & $(0.019)$ & $(0.025)$ \\
\hline$-0.014 *$ & 0.009 & $-0.031 * *$ \\
\hline$(0.006)$ & $(0.007)$ & $(0.007)$ \\
\hline$-0.066 * *$ & $-0.083 * *$ & $-0.046 * *$ \\
\hline$(0.007)$ & $(0.009)$ & $(0.007)$ \\
\hline$-0.034 * *$ & $-0.032 * *$ & $-0.017 * *$ \\
\hline$(0.010)$ & $(0.008)$ & $(0.006)$ \\
\hline 0.010 & 0.015 & $0.040 * *$ \\
\hline$(0.025)$ & $(0.013)$ & $(0.010)$ \\
\hline 0.007 & $0.058 * *$ & -0.012 \\
\hline$(0.022)$ & $(0.013)$ & $(0.022)$ \\
\hline $0.035 * *$ & $-0.021^{\circ}$ & $-0.023 *$ \\
\hline$(0.009)$ & $(0.012)$ & $(0.009)$ \\
\hline-0.015 & 0.014 & $-0.087 * *$ \\
\hline$(0.027)$ & $(0.017)$ & $(0.014)$ \\
\hline$-0.072 *$ & I & -0.021 \\
\hline$(0.028)$ & & $(0.024)$ \\
\hline$-0.057 * *$ & $-0.089 * *$ & $-0.080 * *$ \\
\hline$(0.006)$ & $(0.006)$ & $(0.005)$ \\
\hline$-0.252 * *$ & $-0.150 * *$ & $-0.225 * *$ \\
\hline$(0.017)$ & $(0.015)$ & (0.019) \\
\hline 0.005 & 1 & $-0.077 * *$ \\
\hline$(0.018)$ & & $(0.021)$ \\
\hline$-0.105 * *$ & $-0.128 * *$ & $-0.201 * *$ \\
\hline$(0.024)$ & $(0.017)$ & $(0.015)$ \\
\hline 0.002 & $-0.066 * *$ & 0.006 \\
\hline$(0.031)$ & $(0.022)$ & $(0.022)$ \\
\hline$-0.111 * *$ & $-0.044 * *$ & $-0.092 * *$ \\
\hline$(0.029)$ & $(0.013)$ & $(0.016)$ \\
\hline $0.149 * *$ & $-0.035^{\circ}$ & $-0.026^{*}$ \\
\hline$(0.043)$ & $(0.019)$ & $(0.012)$ \\
\hline$-0.097 * *$ & $-0.097 * *$ & -0.021 \\
\hline$(0.012)$ & $(0.012)$ & $(0.014)$ \\
\hline $0.237 * *$ & $0.264 * *$ & $0.215^{* *}$ \\
\hline$(0.005)$ & $(0.008)$ & $(0.009)$ \\
\hline $0.320 * *$ & I & $0.345^{* *}$ \\
\hline$(0.024)$ & & $(0.024)$ \\
\hline \multirow[t]{2}{*}{1} & 0.102 & $0.128 *$ \\
\hline & $(0.068)$ & $(0.055)$ \\
\hline 0.006 & $0.079 * *$ & 0.022 \\
\hline$(0.017)$ & $(0.013)$ & $(0.014)$ \\
\hline $0.016 * *$ & $0.022 * *$ & $0.030 * *$ \\
\hline$(0.006)$ & $(0.004)$ & $(0.004)$ \\
\hline$-0.052 * *$ & $-0.030 * *$ & $-0.011 *$ \\
\hline$(0.008)$ & $(0.006)$ & $(0.005)$ \\
\hline 0.011 & $0.019 * *$ & $0.028 * *$ \\
\hline$(0.011)$ & $(0.006)$ & $(0.006)$ \\
\hline $0.122^{*}$ & -0.014 & $0.030 * *$ \\
\hline$(0.058)$ & $(0.013)$ & $(0.011)$ \\
\hline
\end{tabular}


Sale of motor vehicles (501)

Maintenance and repair of motor vehicles (502)

Sale of motor vehicle parts and accessories (503)

Sale, maintenance and repair of motorcycles and related parts and accessories (504)

Retail sale of automotive fuel (505)

Wholesale on a fee or contract basis (511)

Wholesale of agricultural raw materials and live animals (512)

Wholesale of food, beverages and tobacco (513)

Wholesale of household goods (514)

Wholesale of non-agricultural intermediate products, waste and scrap (515)

Wholesale of machinery, equipment and supplies (516)

Other wholesale (517)

Retail sale in non-specialised stores (521)

Retail sale of food, beverages and tobacco in specialised stores (522)

Retail sale of pharmaceutical and medical goods, cosmetic and toilet articles (523)

Other retail sale of new goods in specialised store (524)

Retail sale of second-hand goods in stores (525)

Retail sale not in stores (526)

Repair of personal and household goods (527)

Hotels (551)

Camping sites and other provision of short-stay accommodation (552)

Restaurants (553)

Bars (554)

Canteens and catering (555)

Transport via railways (601)

Other land transport (602)

Sea and coastal water transport (611)

Inland water transport (612)

Scheduled air transport (621)

Non-scheduled air transport (622)

\begin{tabular}{|c|c|c|}
\hline $0.029 * *$ & 0.012 & $0.033 * *$ \\
\hline$(0.010)$ & $(0.008)$ & $(0.007)$ \\
\hline$-0.040 * *$ & $0.030 * *$ & $0.020 *$ \\
\hline$(0.008)$ & $(0.010)$ & $(0.009)$ \\
\hline$-0.076^{* *}$ & -0.014 & -0.005 \\
\hline$(0.010)$ & $(0.011)$ & $(0.011)$ \\
\hline$-0.057^{\circ}$ & -0.030 & -0.017 \\
\hline$(0.034)$ & $(0.021)$ & $(0.029)$ \\
\hline$-0.042^{\circ}$ & $-0.115^{* *}$ & $-0.059 * *$ \\
\hline$(0.025)$ & $(0.025)$ & $(0.018)$ \\
\hline $0.154 * *$ & $0.146^{* *}$ & $0.080 * *$ \\
\hline$(0.039)$ & $(0.029)$ & $(0.018)$ \\
\hline$-0.049^{*}$ & $-0.120 * *$ & -0.026 \\
\hline$(0.021)$ & $(0.021)$ & $(0.025)$ \\
\hline$-0.056 * *$ & $-0.060 * *$ & $-0.041 * *$ \\
\hline$(0.008)$ & $(0.007)$ & $(0.007)$ \\
\hline-0.003 & -0.003 & $0.024 * *$ \\
\hline$(0.006)$ & $(0.007)$ & $(0.006)$ \\
\hline $0.030 * *$ & $0.035 * *$ & $0.026 * *$ \\
\hline$(0.007)$ & $(0.009)$ & $(0.007)$ \\
\hline $0.018 * *$ & $0.036 * *$ & $0.028 * *$ \\
\hline$(0.006)$ & $(0.007)$ & $(0.006)$ \\
\hline$-0.065 *$ & 0.018 & -0.028 \\
\hline$(0.031)$ & $(0.026)$ & $(0.021)$ \\
\hline$-0.108 * *$ & $-0.093 * *$ & $-0.057 * *$ \\
\hline$(0.008)$ & $(0.005)$ & $(0.005)$ \\
\hline$-0.172 * *$ & $-0.118 * *$ & $-0.095 * *$ \\
\hline$(0.014)$ & $(0.013)$ & $(0.011)$ \\
\hline$-0.077 * *$ & $-0.110 * *$ & $-0.089 * *$ \\
\hline$(0.016)$ & $(0.013)$ & $(0.022)$ \\
\hline$-0.127 * *$ & $-0.098 * *$ & $-0.085^{* *}$ \\
\hline$(0.008)$ & $(0.007)$ & $(0.006)$ \\
\hline$-0.204 * *$ & $-0.139 * *$ & $-0.139 * *$ \\
\hline$(0.038)$ & $(0.021)$ & $(0.023)$ \\
\hline$-0.067 * *$ & $-0.161 * *$ & $-0.135 * *$ \\
\hline$(0.019)$ & $(0.012)$ & $(0.013)$ \\
\hline$-0.151 * *$ & $-0.074 * *$ & $-0.053 * *$ \\
\hline$(0.038)$ & $(0.012)$ & $(0.014)$ \\
\hline$-0.134 * *$ & $-0.150 * *$ & $-0.155^{* *}$ \\
\hline$(0.014)$ & $(0.010)$ & $(0.008)$ \\
\hline$-0.095 * *$ & $-0.165 * *$ & $-0.144 * *$ \\
\hline$(0.028)$ & $(0.012)$ & $(0.011)$ \\
\hline$-0.156^{* *}$ & $-0.140 * *$ & $-0.170 * *$ \\
\hline$(0.013)$ & $(0.008)$ & $(0.007)$ \\
\hline$-0.124 * *$ & $-0.213 * *$ & $-0.217 * *$ \\
\hline$(0.025)$ & $(0.021)$ & $(0.017)$ \\
\hline$-0.124 * *$ & $-0.163 * *$ & $-0.087 * *$ \\
\hline$(0.017)$ & $(0.010)$ & $(0.010)$ \\
\hline \multirow[t]{2}{*}{1} & I & $0.129 * *$ \\
\hline & & $(0.036)$ \\
\hline$-0.062 * *$ & $-0.092 * *$ & -0.078 \\
\hline$(0.008)$ & $(0.006)$ & $(0.006)$ \\
\hline $0.150 * *$ & $0.110^{* *}$ & 0.018 \\
\hline$(0.032)$ & $(0.026)$ & $(0.022)$ \\
\hline $0.245^{* *}$ & 0.107 & $0.046^{\circ}$ \\
\hline$(0.032)$ & $(0.067)$ & $(0.025)$ \\
\hline $0.185^{* *}$ & $0.086^{* *}$ & 0.034 \\
\hline$(0.034)$ & $(0.020)$ & $(0.030)$ \\
\hline $0.079^{\circ}$ & $0.159 * *$ & $0.314^{* *}$ \\
\hline$(0.046)$ & $(0.032)$ & $(0.046)$ \\
\hline
\end{tabular}


Space transport (623)

Cargo handling and storage (631)

0.036

(0.051)

$0.099 * *$

(0.016)

$-0.086^{* *}$

(0.033)

$-0.065^{* *}$

(0.017)

$0.061 * *$

(0.008)

$-0.125 * *$

(0.024)

$0.347 * *$

(0.033)

$0.122 * *$

(0.004)

$0.105 * *$

(0.013)

$0.062 * *$

$(0.006)$

0.138 *

$(0.058)$

0.005

$(0.013)$

0.060 **

$(0.023)$

$-0.023$

(0.024)

0.006

(0.041)

$-0.013$

$(0.022)$

$-0.033^{\circ}$

(0.019)

$-0.040$

(0.030)

$-0.208 * *$

(0.022)

0.030 **

(0.011)

$-0.003$

(0.013)

$0.127 * *$

$(0.032)$

$-0.086^{\circ}$

(0.048)

$-0.092 *$

(0.041)

$-0.196 * *$

(0.033)

$0.064 * *$

(0.016)

$0.207 * *$

(0.045)

0.094**

(0.007)

0.014

(0.010)

$0.099 * *$
$-0.037 * *$

(0.011)

0.120 **

(0.027)

$-0.132 * *$

(0.014)

$0.047 * *$

(0.010)

$-0.103 * *$

$(0.017)$

0.050 **

(0.017)

$0.073 * *$

(0.006)

$0.075^{* *}$

$(0.016)$

$0.039 * *$

$(0.007)$

0.086 **

(0.023)

0.006

(0.018)

$0.109 * *$

(0.028)

0.007

(0.015)

$0.045^{* *}$

(0.018)

0.038*

(0.016)

$0.176^{* *}$

(0.034)

0.042 *

(0.021)

$-0.122 * *$

(0.028)

$-0.010$

(0.012)

0.015

(0.010)

$-0.055^{* *}$

(0.019)

$-0.009$

(0.021)

$-0.127^{* *}$

(0.016)

0.043

$(0.035)$

$0.068 * *$

(0.010)

$0.238 * *$

(0.042)

$0.106^{* *}$

(0.008)

$-0.008$

(0.010)

0.007
$-0.006$

(0.007)

$0.063 * *$

(0.017)

$-0.045^{* *}$

(0.013)

$0.047 * *$

(0.009)

$-0.061^{* *}$

(0.012)

$0.095 * *$

(0.012)

$0.062 * *$

(0.005)

$0.058 * *$

(0.013)

$0.073 * *$

(0.007)

$0.054 * *$

(0.015)

0.016

(0.014)

$0.126^{* *}$

(0.025)

$0.038^{\circ}$

(0.021)

0.007

(0.016)

0.028

(0.026)

$0.153 * *$

(0.024)

$0.028^{\circ}$

(0.016)

$-0.126 * *$

(0.017)

$0.035^{* *}$

(0.010)

$0.027 * *$

(0.009)

$0.029^{\circ}$

(0.016)

0.017

(0.020)

$-0.091 * *$

(0.014)

0.016

(0.024)

$0.046^{* *}$

(0.011)

$0.060^{*}$

$(0.029)$

$0.097 * *$

(0.008)

$-0.075^{* *}$

(0.010)

0.004 
Advertising (744)

\begin{tabular}{ccc}
$(0.014)$ & $(0.012)$ & $(0.012)$ \\
0.019 & -0.019 & $-0.160^{* *}$ \\
$(0.017)$ & $(0.016)$ & $(0.016)$ \\
$-0.073^{* *}$ & $-0.097 * *$ & $0.091 * *$ \\
$(0.014)$ & $(0.009)$ & $(0.018)$ \\
$-0.121^{* *}$ & $-0.148^{* *}$ & -0.013 \\
$(0.013)$ & $(0.011)$ & $(0.009)$ \\
$-0.020^{* *}$ & -0.005 & -0.008 \\
$(0.007)$ & $(0.008)$ & $(0.008)$ \\
$-0.080^{* *}$ & $0.060^{* *}$ & $-0.050^{* *}$ \\
$(0.014)$ & $(0.010)$ & $(0.007)$ \\
\hline 0.713 & 0.659 & 0.627 \\
$535.5 * *$ & $479.5 * *$ & $405.0 * *$ \\
$50.8 * *$ & $56.6 * *$ & $51.22 * *$ \\
$72.6 \%$ & $75.6 \%$ & $76.1 \%$ \\
$(127 / 175)$ & $(130 / 172)$ & $(137 / 180)$ \\
0.599 & 0.552 & 0.570 \\
0.084 & 0.080 & 0.072 \\
& & \\
175 & 172 & 180 \\
67,023 & 108,677 & 102,594
\end{tabular}

Labour recruitment and provision of personnel (745)

Investigation and security activities (746)

Industrial cleaning (747)

Miscellaneous business activities n.e.c (748)

Adjusted $\mathrm{R}^{2}$ of wage regression

F-test relative to the estimated wage regression

F-test relative to the sectoral dummies

Per cent significant industry wage differentials at the $10 \%$ level

Range of industry wage differentials

Weighted adjusted standard deviation (WASD) of the inter-industry differentials

Number of industries 08,677

102,594

Number of observations

Notes: Standard errors of the industry wage differentials, computed according to Zanchi (1998), are reported between brackets. $* * / * /{ }^{\circ}$ : industry wage differential significant at the 1,5 and $10 \%$, respectively. 
APPENDIX 6: Inter-Industry Wage Differentials and their Dispersion, Including Annual Bonuses, Nace 2-digit (SES 1995, 2002).

\begin{tabular}{|c|c|c|}
\hline Industry (NACE 2-digit) / Data set: & SES 1995 & SES 2002 \\
\hline Mining of coal and lignite; extraction of peat (10) & / & $\begin{array}{l}-0.173 * * \\
(0.023)\end{array}$ \\
\hline Other mining and quarrying (14) & $\begin{array}{c}0.017 \\
(0.015)\end{array}$ & $\begin{array}{l}0.009^{*} \\
(0.004)\end{array}$ \\
\hline Manufacture of food products and beverages (15) & $\begin{array}{c}0.002 \\
(0.006)\end{array}$ & / \\
\hline Manufacture of tobacco products (16) & $\begin{array}{c}0.017 \\
(0.020)\end{array}$ & $\begin{array}{c}0.044 * * \\
(0.013)\end{array}$ \\
\hline Manufacture of textiles (17) & $\begin{array}{c}-0.111 * * \\
(0.007)\end{array}$ & $\begin{array}{c}-0.093 * * \\
(0.006)\end{array}$ \\
\hline Manufacture of wearing apparel; dressing and dyeing of fur (18) & $\begin{array}{c}-0.140 * * \\
(0.011)\end{array}$ & $\begin{array}{l}-0.144 * * \\
(0.011)\end{array}$ \\
\hline $\begin{array}{l}\text { Tanning and dressing of leather; manufacture of luggage, handbags, } \\
\text { saddlery, harness and footwear (19) }\end{array}$ & $\begin{array}{l}-0.020 \\
(0.024)\end{array}$ & $\begin{array}{l}-0.083 * * \\
(0.016)\end{array}$ \\
\hline $\begin{array}{l}\text { Manufacture of wood and products of wood and cork, except furniture; } \\
\text { manufacture of articles of straw and plaiting materials (20) }\end{array}$ & $\begin{array}{c}-0.059 * * \\
(0.007)\end{array}$ & $\begin{array}{l}-0.100 * * \\
(0.006)\end{array}$ \\
\hline Manufacture of pulp, paper and paper products (21) & $\begin{array}{l}0.070^{* *} \\
(0.009)\end{array}$ & $\begin{array}{l}0.062 * * \\
(0.006)\end{array}$ \\
\hline Publishing, printing and reproduction of recorded media (22) & $\begin{array}{l}0.086 * * \\
(0.008)\end{array}$ & $\begin{array}{l}0.022^{\circ} \\
(0.013)\end{array}$ \\
\hline Manufacture of coke, refined petroleum products and nuclear fuel (23) & $\begin{array}{l}0.210^{* *} \\
(0.016)\end{array}$ & $\begin{array}{c}0.193^{* *} \\
(0.016)\end{array}$ \\
\hline Manufacture of chemicals and chemical products (24) & $\begin{array}{l}0.102 * * \\
(0.004)\end{array}$ & $\begin{array}{l}0.109 * * \\
(0.004)\end{array}$ \\
\hline Manufacture of rubber and plastic products (25) & $\begin{array}{l}-0.002 \\
(0.006)\end{array}$ & $\begin{array}{c}-0.019 * * \\
(0.005)\end{array}$ \\
\hline Manufacture of other non-metallic mineral products (26) & $\begin{array}{l}0.013 * \\
(0.006)\end{array}$ & $\begin{array}{l}0.026 * * \\
(0.005)\end{array}$ \\
\hline Manufacture of basic metals (27) & $\begin{array}{l}0.049 * * \\
(0.007)\end{array}$ & $\begin{array}{l}-0.020 * * \\
(0.007)\end{array}$ \\
\hline $\begin{array}{l}\text { Manufacture of fabricated metal products, except machinery and } \\
\text { equipment (28) }\end{array}$ & $\begin{array}{l}-0.001 \\
(0.004)\end{array}$ & $\begin{array}{l}-0.007^{\circ} \\
(0.004)\end{array}$ \\
\hline Manufacture of machinery and equipment n.e.c. (29) & $\begin{array}{c}-0.044 * * \\
(0.005)\end{array}$ & $\begin{array}{l}0.016^{* *} \\
(0.005)\end{array}$ \\
\hline Manufacture of office machinery and computers (30) & $\begin{array}{c}0.040 \\
(0.026)\end{array}$ & $\begin{array}{l}-0.050 * * \\
(0.018)\end{array}$ \\
\hline Manufacture of electrical machinery and apparatus n.e.c. (31) & $\begin{array}{l}-0.014^{\circ} \\
(0.008)\end{array}$ & $\begin{array}{c}0.002 \\
(0.007)\end{array}$ \\
\hline $\begin{array}{l}\text { Manufacture of radio, television and communications equipment and } \\
\text { apparatus (32) }\end{array}$ & $\begin{array}{c}0.003 \\
(0.008)\end{array}$ & $\begin{array}{l}0.104 * * \\
(0.009)\end{array}$ \\
\hline $\begin{array}{l}\text { Manufacture of medical, precision and optical instruments, watches and } \\
\text { clocks (33) }\end{array}$ & $\begin{array}{l}0.036^{* *} \\
(0.013)\end{array}$ & $\begin{array}{l}-0.006 \\
(0.009)\end{array}$ \\
\hline Manufacture of motor vehicles, trailers and semi-trailers (34) & $\begin{array}{l}-0.019 * * \\
(0.005)\end{array}$ & $\begin{array}{l}-0.005 \\
(0.006)\end{array}$ \\
\hline Manufacture of other transport equipment (35) & $\begin{array}{c}0.002 \\
(0.010)\end{array}$ & $\begin{array}{c}-0.028^{* *} \\
(0.008)\end{array}$ \\
\hline Manufacture of furniture; manufacturing n.e.c. (36) & $\begin{array}{c}-0.096 * * \\
(0.007)\end{array}$ & $\begin{array}{c}-0.129 * * \\
(0.006)\end{array}$ \\
\hline Recycling (37) & $\begin{array}{l}-0.050^{* *} \\
(0.014)\end{array}$ & $\begin{array}{l}-0.015 \\
(0.010)\end{array}$ \\
\hline Electricity, gas, steam and hot water supply (40) & $\begin{array}{l}0.322 * * \\
(0.006)\end{array}$ & $\begin{array}{c}0.345 * * \\
(0.010)\end{array}$ \\
\hline Collection, purification and distribution of water (41) & / & $\begin{array}{c}0.242 * * \\
(0.086)\end{array}$ \\
\hline Construction (45) & $\begin{array}{c}-0.050 * * \\
(0.005)\end{array}$ & $\begin{array}{c}-0.010^{* * *} \\
(0.004)\end{array}$ \\
\hline
\end{tabular}


Sale, maintenance and repair of motor vehicles and motorcycles; retail sale of automotive fuel (50)

\begin{tabular}{|c|c|}
\hline$-0.027 * *$ & $0.040 * *$ \\
\hline$(0.006)$ & $(0.005)$ \\
\hline $0.008 *$ & $0.029 * *$ \\
\hline$(0.003)$ & $(0.003)$ \\
\hline$-0.090 * *$ & $-0.058 * *$ \\
\hline$(0.006)$ & $(0.004)$ \\
\hline$-0.108 * *$ & $-0.209 * *$ \\
\hline$(0.009)$ & $(0.006)$ \\
\hline$-0.085^{* *}$ & $-0.091 * *$ \\
\hline$(0.008)$ & $(0.006)$ \\
\hline $0.223 * *$ & 0.018 \\
\hline$(0.024)$ & $(0.018)$ \\
\hline $0.164 * *$ & $0.114 * *$ \\
\hline$(0.030)$ & $(0.028)$ \\
\hline $0.032 * *$ & $0.020 * *$ \\
\hline$(0.008)$ & $(0.005)$ \\
\hline $0.322 * *$ & $0.100 * *$ \\
\hline$(0.033)$ & $(0.011)$ \\
\hline $0.130 * *$ & $0.083 * *$ \\
\hline$(0.004)$ & $(0.006)$ \\
\hline $0.058 * *$ & $0.085 * *$ \\
\hline$(0.006)$ & $(0.008)$ \\
\hline 0.005 & $0.049 * *$ \\
\hline$(0.013)$ & $(0.012)$ \\
\hline-0.005 & $0.040 * *$ \\
\hline$(0.025)$ & $(0.015)$ \\
\hline$-0.041 *$ & $0.035 * *$ \\
\hline$(0.017)$ & $(0.014)$ \\
\hline 0.004 & $0.030 * *$ \\
\hline$(0.008)$ & $(0.007)$ \\
\hline $0.049 * *$ & $0.032 * *$ \\
\hline$(0.016)$ & $(0.011)$ \\
\hline-0.004 & 0.006 \\
\hline$(0.004)$ & $(0.005)$ \\
\hline 0.720 & 0.649 \\
\hline $1,350.6 * *$ & $1,071.0 * *$ \\
\hline $165.1 * *$ & $171.0^{* *}$ \\
\hline $69.8 \%$ & $86.4 \%$ \\
\hline$(30 / 43)$ & $(38 / 44)$ \\
\hline 0.462 & 0.554 \\
\hline 0.081 & 0.074 \\
\hline 43 & 44 \\
\hline 67,023 & 102,594 \\
\hline
\end{tabular}

Wholesale trade and commission trade, except of motor vehicles and motorcycles (51)

Retail trade, except of motor vehicles and motorcycles; repair of personal and household goods (52)

Hotels and restaurants (55)

Land transport; transport via pipelines (60)

Water transport (61)

Air transport (62)

Supporting and auxiliary transport activities; activities of travel agencies (63)

Post and telecommunications (64)

Financial intermediation, except insurance and pension funding (65)

Insurance and pension funding, except compulsory social security (66)

Activities auxiliary to financial intermediation (67)

Real estate activities (70)

Renting of machinery and equipment without operator and of personal and household goods (71)

Computer and related activities (72)

Research and development (73)

Other businesses activities (74)

Adjusted $\mathrm{R}^{2}$ of wage regression

F-test relative to the estimated relation

F-test relative to the sectoral dummies

Per cent significant industry wage differentials at the $10 \%$ level.

Range of industry wage differentials

Weighted adjusted standard deviation (WASD) of the

inter-industry differentials

Number of industries

102,594

Notes: Standard errors of the industry wage differentials, computed according to Zanchi (1998), are reported between brackets. $* * / * /{ }^{\circ}$ : industry wage differential significant at the 1,5 and $10 \%$, respectively. 
APPENDIX 7: Inter-Industry Wage Differentials and their Dispersion, Including Annual Bonuses, Nace 3-digit (SES 1995, 2002).

\begin{tabular}{|c|c|c|}
\hline Industry (Nace 3-digit) / Data set: & SES 1995 & SES 2002 \\
\hline Mining and agglomeration of hard coal (101) & / & $\begin{array}{c}-0158 * * \\
(0.030)\end{array}$ \\
\hline Extraction and agglomeration of peat (103) & / & $\begin{array}{c}-0.178 * * \\
(0.034)\end{array}$ \\
\hline Quarrying of stone (141) & $\begin{array}{c}0.019 \\
(0.017)\end{array}$ & $\begin{array}{c}0.045 * * \\
(0.013)\end{array}$ \\
\hline Quarrying of sand and clay (142) & $\begin{array}{c}0.095 * * \\
(0.030)\end{array}$ & $\begin{array}{c}0.071 * * \\
(0.021)\end{array}$ \\
\hline Mining of chemical and fertiliser minerals (143) & $\begin{array}{c}-0.033 \\
(0.084)\end{array}$ & $\begin{array}{c}-0.031 \\
(0.022)\end{array}$ \\
\hline Other mining and quarrying n.e.c. (145) & $\begin{array}{c}-0.218 * * \\
(0.024)\end{array}$ & $\begin{array}{c}0.035 \\
(0.030)\end{array}$ \\
\hline Production, processing and preserving of meat and meat products (151) & $\begin{array}{c}0.006 \\
(0.009)\end{array}$ & $\begin{array}{l}-0.018 * \\
(0.007)\end{array}$ \\
\hline Processing and preserving of fish and fish products (152) & $\begin{array}{c}-0.023 \\
(0.017)\end{array}$ & $\begin{array}{c}0.022 \\
(0.021)\end{array}$ \\
\hline Processing and preserving of fruit and vegetables (153) & $\begin{array}{c}-0.083 * * \\
(0.011)\end{array}$ & $\begin{array}{l}-0.015 \\
(0.010)\end{array}$ \\
\hline Manufacture of vegetable and animal oils and fats (154) & $\begin{array}{c}0.061 * * \\
(0.018)\end{array}$ & $\begin{array}{c}0.083 * * \\
(0.022)\end{array}$ \\
\hline Manufacture of dairy products (155) & $\begin{array}{c}0.009 \\
(0.012)\end{array}$ & $\begin{array}{l}-0.014 \\
(0.009)\end{array}$ \\
\hline Manufacture of grain mill products, starches and starch products (156) & $\begin{array}{c}0.056 * * \\
(0.017)\end{array}$ & $\begin{array}{c}0.110 * * \\
(0.016)\end{array}$ \\
\hline Manufacture of prepared animal feeds (157) & $\begin{array}{l}0.032^{\circ} \\
(0.017)\end{array}$ & $\begin{array}{c}0.015 \\
(0.016)\end{array}$ \\
\hline Manufacture of other food products (158) & $\begin{array}{c}0.003 \\
(0.011)\end{array}$ & $\begin{array}{c}0.020 * * \\
(0.007)\end{array}$ \\
\hline Manufacture of beverages (159) & $\begin{array}{c}-0.027 * \\
(0.012)\end{array}$ & $\begin{array}{c}0.007 \\
(0.009)\end{array}$ \\
\hline Manufacture of tobacco product (160) & $\begin{array}{c}0.022 \\
(0.019)\end{array}$ & $\begin{array}{c}0.051 * * \\
(0.013)\end{array}$ \\
\hline Preparation and spinning of textile fibres (171) & $\begin{array}{c}-0.135^{* *} \\
(0.018)\end{array}$ & $\begin{array}{c}-0.049 * * \\
(0.014)\end{array}$ \\
\hline Textile weaving (172) & $\begin{array}{c}-0.111 * * \\
(0.012)\end{array}$ & $\begin{array}{c}-0.053 * * \\
(0.010)\end{array}$ \\
\hline Finishing of textiles (173) & $\begin{array}{c}-0.154 * * \\
(0.033)\end{array}$ & $\begin{array}{c}-0.093 * * \\
(0.011)\end{array}$ \\
\hline Manufacture of made-up textile articles, except apparel (174) & $\begin{array}{c}-0.131^{* *} \\
(0.015)\end{array}$ & $\begin{array}{c}-0.131^{* *} \\
(0.016)\end{array}$ \\
\hline Manufacture of other textiles (175) & $\begin{array}{c}-0.051^{* *} \\
(0.011)\end{array}$ & $\begin{array}{c}-0.093 * * \\
(0.010)\end{array}$ \\
\hline Manufacture of knitted and crocheted fabrics (176) & $\begin{array}{c}-0.171 * * \\
(0.064)\end{array}$ & $\begin{array}{c}-0.074 * * \\
(0.019)\end{array}$ \\
\hline Manufacture of knitted and crocheted articles (177) & $\begin{array}{c}-0.318^{* *} \\
(0.024)\end{array}$ & $\begin{array}{c}-0.174 * * \\
(0.014)\end{array}$ \\
\hline Manufacture of other wearing apparel and accessories (182) & $\begin{array}{c}-0.147 * * \\
(0.011)\end{array}$ & $\begin{array}{c}-0.142 * * \\
(0.011)\end{array}$ \\
\hline Dressing and dyeing of fur; manufacture of articles of fur (183) & $\begin{array}{c}-0.188 * * \\
(0.030)\end{array}$ & $\begin{array}{c}-0.112 * * \\
(0.036)\end{array}$ \\
\hline Tanning and dressing of leather (191) & $\begin{array}{c}-0.125^{* *} \\
(0.016)\end{array}$ & $\begin{array}{c}-0.126^{* *} \\
(0.032)\end{array}$ \\
\hline Manufacture of luggage, handbags and the like, saddlery and harness (192) & $\begin{array}{c}0.056 \\
(0.043)\end{array}$ & $\begin{array}{c}-0.064 * * \\
(0.022)\end{array}$ \\
\hline Manufacture of footwear (193) & $\begin{array}{c}-0.067 * * \\
(0.022)\end{array}$ & $\begin{array}{c}-0.101 * * \\
(0.019)\end{array}$ \\
\hline
\end{tabular}


Sawmilling and planing of wood, impregnation of wood (201)

\begin{tabular}{|c|c|}
\hline$-0.089 * *$ & $-0.118 * *$ \\
\hline$(0.014)$ & $(0.011)$ \\
\hline 0.011 & $-0.082 * *$ \\
\hline$(0.016)$ & $(0.012)$ \\
\hline$-0.075 * *$ & $-0.100 * *$ \\
\hline$(0.008)$ & $(0.010)$ \\
\hline-0.019 & $-0.083 * *$ \\
\hline$(0.024)$ & $(0.015)$ \\
\hline$-0.097 * *$ & $-0.093 * *$ \\
\hline$(0.030)$ & $(0.012)$ \\
\hline $0.196 * *$ & $0.134 * *$ \\
\hline$(0.016)$ & $(0.012)$ \\
\hline $0.024 *$ & $0.046^{* *}$ \\
\hline$(0.011)$ & $(0.007)$ \\
\hline 0.007 & $-0.059 * *$ \\
\hline$(0.018)$ & $(0.020)$ \\
\hline $0.088 * *$ & $0.122 * *$ \\
\hline$(0.008)$ & $(0.007)$ \\
\hline & 0.029 \\
\hline 1 & $(0.041)$ \\
\hline $0.124 * *$ & $0.186 * *$ \\
\hline$(0.039)$ & $(0.028)$ \\
\hline $0.290 * *$ & $0.276^{* *}$ \\
\hline$(0.020)$ & $(0.020)$ \\
\hline $0.044^{\circ}$ & -0.002 \\
\hline$(0.024)$ & $(0.017)$ \\
\hline $0.161 * *$ & $0.168 * *$ \\
\hline$(0.005)$ & $(0.006)$ \\
\hline $0.093 * *$ & $0.201 * *$ \\
\hline$(0.032)$ & $(0.028)$ \\
\hline $0.075 * *$ & $0.036 * *$ \\
\hline$(0.017)$ & $(0.011)$ \\
\hline $0.032 * *$ & $0.087 * *$ \\
\hline$(0.008)$ & $(0.010)$ \\
\hline-0.016 & $-0.045 * *$ \\
\hline$(0.013)$ & $(0.010)$ \\
\hline $0.101 * *$ & $0.134 * *$ \\
\hline$(0.013)$ & $(0.010)$ \\
\hline $0.042 *$ & 0.002 \\
\hline$(0.018)$ & $(0.017)$ \\
\hline-0.019 & -0.012 \\
\hline$(0.017)$ & $(0.011)$ \\
\hline 0.002 & $-0.011^{\circ}$ \\
\hline$(0.007)$ & $(0.006)$ \\
\hline-0.008 & 0.011 \\
\hline$(0.011)$ & $(0.009)$ \\
\hline-0.019 & $-0.051 * *$ \\
\hline$(0.019)$ & $(0.014)$ \\
\hline$-0.049 * *$ & 0.022 \\
\hline$(0.018)$ & $(0.018)$ \\
\hline-0.025 & $0.033 * *$ \\
\hline$(0.016)$ & $(0.012)$ \\
\hline $0.150 * *$ & $0.203 * *$ \\
\hline$(0.015)$ & $(0.019)$ \\
\hline 0.010 & $0.041 * *$ \\
\hline (0.009) & $(0.008)$ \\
\hline-0.007 & 0.002 \\
\hline$(0.028)$ & $(0.020)$ \\
\hline $0.080 *$ & 0.016 \\
\hline$(0.037)$ & $(0.018)$ \\
\hline
\end{tabular}

Manufacture of veneer sheets; manufacture of plywood, laminboard, particle

board, fibre board and other panels and boards (202)

Manufacture of builders' carpentry and joinery (203)

Manufacture of wooden containers (204)

Manufacture of other products of wood; manufacture of articles of cork, straw and plaiting materials (205)

Manufacture of pulp, paper and paperboard (211)

Manufacture of articles of paper and paperboard (212)

Publishing (221)

Printing and service activities related to printing (222)

Reproduction of recorded media (223)

Manufacture of coke oven products (231)

Manufacture of refined petroleum products (232)

Processing of nuclear fuel (233)

Manufacture of basic chemicals (241)

Manufacture of pesticides and other agro-chemical products (242)

Manufacture of paints, varnishes and similar coatings, printing ink and mastics (243)

Manufacture of pharmaceuticals, medicinal chemicals and botanical product (244)

Manufacture of soap and detergents, cleaning and polishing preparations, perfumes and toilet preparations (245)

Manufacture of other chemical products (246)

Manufacture of man-made fibres (247)

Manufacture of rubber products (251)

Manufacture of plastic products (252)

Manufacture of glass and glass products (261)

Manufacture of non-refractory ceramic goods other than for construction purposes; manufacture of refractory ceramic products (262)

Manufacture of ceramic tiles and flags (263)

Manufacture of bricks, tiles and construction products, in baked clay (264)

Manufacture of cement, lime and plaster (265)

Manufacture of articles of concrete, plaster and cement (266)

Cutting, shaping and finishing of stone (267)

Manufacture of other non-metallic mineral products (268)

$(0.037)$

$(0.018)$ 
Manufacture of tubes (272)

Other first processing of iron and steel and production of non-ECSC ferro-alloys

Casting of metals (275)

Manufacture of structural metal products (281)

$(0.011)$

$-0.028$

$0.074 * *$

$(0.018)$

$(0.011)$

$0.076^{* *}$

$-0.013$

$(0.010)$

$(0.011)$

$-0.037 * *$

0.005

$(0.009)$

(0.009)

$-0.017 * *$

Manufacture of tanks, reservoirs and containers of metal; manufacture of central

0.006

(0.006)

heating radiators and boilers (282)

$(0.011)$

$-0.020 *$

Manufacture of steam generators, except central heating hot water boilers (283)

$-0.054 * *$

$(0.009)$

$(0.018)$

Forging, pressing, stamping and roll forming of metal; powder metallurgy (284)

Treatment and coating of metals; general mechanical engineering (285)

$(0.017)$

$-0.022^{\circ}$

$-0.013$

$(0.012)$

(0.010)

0.005

Manufacture of cutlery, tools and general hardware (286)

Manufacture of other fabricated metal products (287)

$-0.001$

$(0.008)$

(0.013)

0.009

$-0.003$

(0.012)

(0.014)

0.015

Manufacture of machinery for the production and use of mechanical power, except aircraft, vehicle and cycle engines (291)

$0.023^{*}$

(0.009)

Manufacture of other general purpose machinery (292)

(0.011)

$0.063 * *$

$-0.058 * *$

(0.011)

(0.008)

0.011

Manufacture of agricultural and forestry machinery (293)

Manufacture of machine-tools (294)

Manufacture of other special purpose machinery (295)

Manufacture of weapons and ammunition (296)

$-0.033 * *$

$(0.008)$

$-0.049^{*} \quad 0.006$

$(0.024) \quad(0.014)$

$-0.061 * * \quad-0.002$

$(0.007) \quad(0.008)$

$0.108 * * \quad 0.087 * *$

(0.012) (0.019)

Manufacture of domestic appliances n.e.c. (297)

$-0.106^{* *}$

$-0.039 * *$

Manufacture of office machinery and computers (300)

(0.018)

(0.015)

0.029

$-0.043^{*}$

Manufacture of electric motors, generators and transformers (311)

Manufacture of electricity distribution and control apparatus (312)

$(0.026)$

(0.018)

$-0.018$

0.013

(0.016)

(0.015)

0.016

$-0.027 * *$

Manufacture of insulated wire and cable (313)

(0.012)

(0.010)

$0.047 * *$

0.040 *

(0.013)

(0.020)

Manufacture of accumulators, primary cells and primary batteries (314)

$0.036^{\circ}$

$0.066^{* *}$

Manufacture of lighting equipment and electric lamps (315)

(0.021)

(0.020)

$-0.036^{*}$

$0.046^{* *}$

(0.018)

(0.013)

Manufacture of electrical equipment n.e.c. (316)

$-0.156^{* *}$

0.003

(0.022)

(0.038)

Manufacture of electronic valves and tubes and other electronic components

$-0.005$

$0.092 * *$

(321)

(0.015)

$0.045 * *$

(0.013)

Manufacture of television and radio transmitters and apparatus for line telephony

(0.009)

$-0.109 * *$

$0.163 * *$

and line telegraphy (322)

Manufacture of television and radio receivers, sound or video recording or reproducing apparatus and associated goods (323)

$(0.013)$

$(0.017)$

Manufacture of medical and surgical equipment and orthopaedic appliances (331)

$0.080 *$ 
Manufacture of instruments and appliances for measuring, checking, testing,

$0.100 * * \quad 0.061 * *$ navigating and other purposes, except industrial process control equipment (332)

Manufacture of industrial process control equipment (333)

Manufacture of optical instruments and photographic equipment (334)

$(0.023)$

(0.017)

$-0.118^{* *} \quad-0.039^{\circ}$

$(0.040) \quad(0.023)$

Manufacture of watches and clocks (335)

$-0.115^{* *}$

$-0.046^{\circ}$

Manufacture of motor vehicles (341)

$(0.026)$

(0.025)

$0.023 * * \quad 0.007$

$(0.006) \quad(0.008)$

Manufacture of bodies (coachwork) for motor vehicles; manufacture of trailers $-0.070 * *$ $-0.019 * *$ and semi-trailers (342)

$(0.007)$

$(0.007)$

Manufacture of parts and accessories for motor vehicles and their engines (343)

$-0.045^{*}$

Building and repairing of ships and boats (351)

0.019

(0.007)

(0.029)

$0.035^{* *}$

Manufacture of railway and tramway locomotives and rolling stock (352)

0.032

(0.012)

(0.026)

$-0.011$

Manufacture of aircraft and spacecraft (353)

0.015

(0.022)

(0.010)

$-0.035^{* *}$

Manufacture of motorcycles and bicycles (354)

$-0.033$

(0.010)

(0.026)

$-0.054 * *$

Manufacture of other transport equipment n.e.c. (355)

$-0.062 *$

$(0.015)$

(0.030)

$-0.013$

Manufacture of furniture (361)

Manufacture of jewellery and related articles (362)

$-0.074 * *$

(0.025)

(0.007)

$-0.113 * *$

$-0.308 * *$

(0.006)

$(0.018)$

$-0.276^{* *}$

Manufacture of musical instruments (363)

0.006

(0.021)

$(0.019)$

$-0.136^{* *}$

$-0.134 * *$

Manufacture of sports goods (364)

Manufacture of games and toys (365)

$(0.024)$

(0.021)

0.012

$-0.247 * *$

$(0.031)$

(0.016)

Miscellaneous manufacturing n.e.c (366)

$-0.113 * *$

$0.040^{*}$

$(0.032)$

0.021

Recycling of metal waste and scrap (371)

$0.163 * *$

$(0.017)$

$(0.044)$

$-0.091 * *$

$-0.006$

Recycling of non-metal waste and scrap (372)

$(0.012)$

$0.335 * *$

(0.006)

$0.401 * *$

(0.012)

Production and distribution of electricity (401)

Manufacture of gas; distribution of gaseous fuels through mains (402)

(0.027)

Collection, purification and distribution of water (410)

Site preparation (451)

Building of complete constructions or parts thereof; civil engineering (452)

Building installation (453)

Building completion (454)

Renting of construction or demolition equipment with operator (455)

Sale of motor vehicles (501)

$-0.019$

(0.015)

$0.336 * *$

(0.011) 
Sale of motor vehicle parts and accessories (503)

\begin{tabular}{|c|c|}
\hline$-0.069 * *$ & 0.015 \\
\hline$(0.012)$ & $(0.011)$ \\
\hline-0.021 & 0.017 \\
\hline$(0.036)$ & $(0.026)$ \\
\hline-0.034 & -0.035 \\
\hline$(0.026)$ & $(0.028)$ \\
\hline $0.187 * *$ & $0.102 * *$ \\
\hline$(0.045)$ & $(0.020)$ \\
\hline$-0.058 * *$ & -0.012 \\
\hline$(0.020)$ & $(0.026)$ \\
\hline$-0.041 * *$ & $-0.023 * *$ \\
\hline$(0.008)$ & $(0.008)$ \\
\hline 0.010 & $0.046^{* *}$ \\
\hline$(0.006)$ & $(0.006)$ \\
\hline $0.037 * *$ & $0.034 * *$ \\
\hline$(0.008)$ & $(0.007)$ \\
\hline $0.032 * *$ & $0.039 * *$ \\
\hline$(0.006)$ & $(0.006)$ \\
\hline$-0.098 * *$ & $-0.037^{\circ}$ \\
\hline$(0.034)$ & $(0.022)$ \\
\hline$-0.078 * *$ & $-0.063 * *$ \\
\hline$(0.009)$ & $(0.006)$ \\
\hline$-0.157 * *$ & $-0.074 * *$ \\
\hline$(0.014)$ & $(0.016)$ \\
\hline$-0.043^{*}$ & $-0.095 * *$ \\
\hline$(0.017)$ & $(0.022)$ \\
\hline$-0.130 * *$ & $-0.078 * *$ \\
\hline$(0.008)$ & $(0.006)$ \\
\hline$-0.213 * *$ & $-0.158 * *$ \\
\hline$(0.034)$ & $(0.024)$ \\
\hline$-0.045^{*}$ & $-0.109 * *$ \\
\hline$(0.020)$ & $(0.013)$ \\
\hline$-0.170 * *$ & $-0.059 * *$ \\
\hline$(0.041)$ & $(0.015)$ \\
\hline$-0.164 * *$ & $-0.224 * *$ \\
\hline$(0.015)$ & $(0.009)$ \\
\hline$-0.127^{* *}$ & $-0.193 * *$ \\
\hline$(0.027)$ & $(0.013)$ \\
\hline$-0.191 * *$ & $-0.254 * *$ \\
\hline$(0.013)$ & $(0.008)$ \\
\hline$-0.108 * *$ & $-0.311 * *$ \\
\hline$(0.025)$ & $(0.018)$ \\
\hline$-0.144 * *$ & $-0.147 * *$ \\
\hline$(0.019)$ & $(0.011)$ \\
\hline 1 & $0.091 *$ \\
\hline & $(0.038)$ \\
\hline$-0.089 * *$ & $-0.094 * *$ \\
\hline$(0.008)$ & $(0.006)$ \\
\hline $0.205 * *$ & 0.030 \\
\hline$(0.032)$ & $(0.022)$ \\
\hline $0.267 * *$ & 0.009 \\
\hline$(0.032)$ & $(0.027)$ \\
\hline $0.193^{* *}$ & 0.006 \\
\hline$(0.033)$ & $(0.032)$ \\
\hline 0.027 & $0.312 * *$ \\
\hline$(0.048)$ & $(0.045)$ \\
\hline 0.057 & \\
\hline$(0.061)$ & p \\
\hline $0.108 * *$ & -0.003 \\
\hline$(0.018)$ & $(0.008)$ \\
\hline
\end{tabular}

Sale, maintenance and repair of motorcycles and related parts and accessories (504)

Retail sale of automotive fuel (505)

Wholesale on a fee or contract basis (511)

Wholesale of agricultural raw materials and live animals (512)

Wholesale of food, beverages and tobacco (513)

Wholesale of household goods (514)

Wholesale of non-agricultural intermediate products, waste and scrap (515)

Wholesale of machinery, equipment and supplies (516)

Other wholesale (517)

Retail sale in non-specialised stores (521)

Retail sale of food, beverages and tobacco in specialised stores (522)

Retail sale of pharmaceutical and medical goods, cosmetic and toilet articles (523)

Other retail sale of new goods in specialised store (524)

Retail sale of second-hand goods in stores (525)

Retail sale not in stores (526)

Repair of personal and household goods (527)

Hotels (551)

Camping sites and other provision of short-stay accommodation (552)

Restaurants (553)

Bars (554)

Canteens and catering (555)

Transport via railways (601)

Other land transport (602)

Sea and coastal water transport (611)

Inland water transport (612)

Scheduled air transport (621)

Non-scheduled air transport (622)

Space transport (623)

Cargo handling and storage (631) 
Other supporting transport activities (632)

Activities of travel agencies and tour operators; tourist assistance activities n.e.c. (633)

Activities of other transport agencies (634)

Post and courier activities (641)

Telecommunications (642)

Monetary intermediation (651)

Other financial intermediation (652)

Insurance and pension funding, except compulsory social security (660)

Activities auxiliary to financial intermediation, except insurance and pension funding (671)

Activities auxiliary to insurance and pension funding (672)

Real estate activities with own property (701)

Letting of own property (702)

Real estate activities on a fee or contract basis (703)

Renting of automobiles (711)

Renting of other transport equipment (712)

Renting of other machinery and equipment (713)

Renting of personal and household goods n.e.c. (714)

Hardware consultancy (721)

Software consultancy and supply (722)

Data processing (723)

Data base activities (724)

Maintenance and repair of office, accounting and computing machinery (725)

Other computer related activities (726)

Research and experimental development on natural sciences and engineering (731)

Research and experimental development on social sciences and humanities (732)

Legal, accounting, book-keeping and auditing activities; tax consultancy; market research and public opinion polling; business and management consultancy; holdings (741)

Architectural and engineering activities and related technical consultancy (742)

Technical testing and analysis (743)

Advertising (744)

Labour recruitment and provision of personnel (745)

\begin{tabular}{|c|c|}
\hline$-0.063^{\circ}$ & $0.074 * *$ \\
\hline$(0.033)$ & $(0.018)$ \\
\hline$-0.051 * *$ & $-0.028 *$ \\
\hline$(0.017)$ & $(0.013)$ \\
\hline $0.050 * *$ & $0.057 * *$ \\
\hline$(0.009)$ & $(0.009)$ \\
\hline$-0.148 * *$ & $-0.071 * *$ \\
\hline$(0.024)$ & $(0.013)$ \\
\hline $0.437 * *$ & $0.155 * *$ \\
\hline$(0.036)$ & $(0.013)$ \\
\hline $0.141 * *$ & $0.084 * *$ \\
\hline$(0.004)$ & $(0.006)$ \\
\hline $0.137 * *$ & $0.092 * *$ \\
\hline$(0.014)$ & $(0.016)$ \\
\hline $0.069 * *$ & $0.086 * *$ \\
\hline$(0.006)$ & $(0.007)$ \\
\hline $0.137 * *$ & $0.102 * *$ \\
\hline$(0.053)$ & $(0.018)$ \\
\hline 0.002 & 0.000 \\
\hline$(0.014)$ & $(0.015)$ \\
\hline 0.021 & $0.126^{* *}$ \\
\hline$(0.037)$ & $(0.026)$ \\
\hline$-0.074 * *$ & 0.030 \\
\hline$(0.026)$ & $(0.022)$ \\
\hline 0.031 & 0.023 \\
\hline$(0.040)$ & $(0.018)$ \\
\hline-0.012 & $0.079 * *$ \\
\hline$(0.024)$ & $(0.028)$ \\
\hline$-0.065 * *$ & $0.146^{* *}$ \\
\hline$(0.023)$ & $(0.023)$ \\
\hline-0.042 & $0.041 *$ \\
\hline$(0.032)$ & $(0.016)$ \\
\hline$-0.241 * *$ & $-0.142 * *$ \\
\hline$(0.023)$ & $(0.017)$ \\
\hline $0.026^{*}$ & $0.041 * *$ \\
\hline$(0.012)$ & $(0.010)$ \\
\hline 0.007 & $0.043 * *$ \\
\hline$(0.014)$ & $(0.010)$ \\
\hline $0.135 * *$ & $0.030^{\circ}$ \\
\hline$(0.032)$ & $(0.017)$ \\
\hline-0.069 & 0.017 \\
\hline$(0.048)$ & $(0.021)$ \\
\hline$-0.081^{\circ}$ & $-0.064 * *$ \\
\hline$(0.041)$ & $(0.016)$ \\
\hline$-0.164 * *$ & 0.036 \\
\hline$(0.044)$ & $(0.027)$ \\
\hline $0.061 * *$ & 0.036 \\
\hline$(0.016)$ & $(0.011)$ \\
\hline $0.191 * *$ & 0.043 \\
\hline$(0.044)$ & $(0.029)$ \\
\hline $0.098 * *$ & $0.110 * *$ \\
\hline$(0.008)$ & $(0.008)$ \\
\hline $0.018^{\circ}$ & $-0.063 * *$ \\
\hline$(0.011)$ & $(0.011)$ \\
\hline $0.117 * *$ & 0.013 \\
\hline$(0.014)$ & $(0.012)$ \\
\hline 0.018 & $-0.195 * *$ \\
\hline$(0.017)$ & $(0.017)$ \\
\hline$-0.102 * *$ & $0.066^{* *}$ \\
\hline
\end{tabular}


(0.015)

$(0.021)$

Investigation and security activities (746)

$-0.193 * *$

Industrial cleaning (747)

Adjusted $\mathrm{R}^{2}$ of wage regression

$(0.015)$ 0.008

F-test relative to the estimated wage regression

$0.733 \quad 0.662$

F-test relative to the sectoral dummies

Per cent significant industry wage differentials at the $10 \%$ level

Weighted adjusted standard deviation (WASD) of the inter-industry differentials

Notes: Standard errors of the industry wage differentials, computed according to Zanchi (1998), are reported between brackets. $* * / * /{ }^{\circ}$ : industry wage differential significant at the 1,5 and $10 \%$, respectively.

APPENDIX 8: Pearson / Spearman Correlation Coefficients Between Industry Wage Differentials, Excluding Annual Bonuses, Nace 3-digit (SES 1995, 1999, 2002)

\begin{tabular}{|l|c|c|}
\hline & SES 1995 & SES 2002 \\
\hline SES 1999 & $0.738^{* * / 0.742^{* *}}$ & $0.816^{* *} / 0.792^{* *}$ \\
& $(\mathrm{n}=168)$ & $(\mathrm{n}=171)$ \\
\hline SES 2002 & $0.709^{* *} / 0.703^{* *}$ & \\
& $(\mathrm{n}=174)$ & \\
\hline
\end{tabular}

Notes: $\mathrm{n}$ stands for the number of observations/sectors.

$* * / * / 0$ : correlation coefficient significant at 1,5 and $10 \%$, respectively.

APPENDIX 9: Pearson / Spearman Correlation Coefficients Between Industry Wage Differentials, Including Annual Bonuses, Nace 2- and 3-digit (SES 1995, 2002)

\begin{tabular}{|l|l|c|}
\hline \multicolumn{2}{|c|}{} & SES 2002 \\
\hline SES 1995 & Nace 2-digit & $\begin{array}{c}0.796 * * / 0.729 * * \\
(\mathrm{n}=42)\end{array}$ \\
\cline { 2 - 3 } & Nace 3-digit & $\begin{array}{c}0.700 * * / 0.658 * * \\
(\mathrm{n}=174)\end{array}$ \\
\hline
\end{tabular}

Notes: $\mathrm{n}$ stands for the number of observations/sectors.

$* * / * / \circ$ : correlation coefficient significant at the 1,5 and $10 \%$, respectively. 
Appendix 10: Industry Coefficients along the Distribution and their Difference, Nace 2digit, Including Annual Bonuses (SES 1995)

Industry (NACE 2-digit):

10th 90th Difference

percentile percentile between 90 th and

Other mining and quarrying (14)

Manufacture of food products and beverages (15)

Manufacture of tobacco products (16)

Manufacture of textiles (17)

Manufacture of wearing apparel; dressing and dyeing of fur (18)

Tanning and dressing of leather; manufacture of luggage,

handbags, saddlery, harness and footwear (19)

Manufacture of wood and products of wood and cork, except

furniture; manufacture of articles of straw and plaiting materials (20)

Manufacture of pulp, paper and paper products (21)

Publishing, printing and reproduction of recorded media (22)

Manufacture of coke, refined petroleum products and nuclear fuel (23)

Manufacture of chemicals and chemical products (24)

Manufacture of rubber and plastic products (25)

Manufacture of other non-metallic mineral products (26)

Manufacture of basic metals (27)

Manufacture of fabricated metal products, except machinery and equipment (28)

Manufacture of machinery and equipment n.e.c. (29)

Manufacture of office machinery and computers (30)

Manufacture of electrical machinery and apparatus n.e.c. (31)

Manufacture of radio, television and communications equipment and apparatus (32)

Manufacture of medical, precision and optical instruments, watches and clocks (33)

Manufacture of motor vehicles, trailers and semi-trailers (34)

Manufacture of other transport equipment (35)

Manufacture of furniture; manufacturing n.e.c. (36)

Recycling (37)

Electricity, gas, steam and hot water supply (40)

Construction (45)

Sale, maintenance and repair of motor vehicles and motorcycles;

\begin{tabular}{|c|c|c|}
\hline $0.043 *$ & $0084 * *$ & 0041 \\
\hline$(0.021)$ & $(0.028)$ & $(0.035)$ \\
\hline $0.063 * *$ & $0.113^{* *}$ & $0.050 * *$ \\
\hline$(0.007)$ & $(0.012)$ & $(0.014)$ \\
\hline $0.080 * *$ & $0.143^{* *}$ & $0.062^{\circ}$ \\
\hline$(0.023)$ & $(0.023)$ & $(0.033)$ \\
\hline$-0.085 * *$ & 0.013 & $0.098 * *$ \\
\hline$(0.011)$ & $(0.013)$ & $(0.017)$ \\
\hline$-0.101 * *$ & -0.004 & $0.097 * *$ \\
\hline$(0.011)$ & $(0.029)$ & $(0.031)$ \\
\hline $0.024^{\circ}$ & 0.022 & -0.002 \\
\hline$(0.014)$ & $(0.027)$ & $(0.031)$ \\
\hline $0.051 * *$ & $0.033 *$ & -0.018 \\
\hline$(0.009)$ & $(0.015)$ & $(0.018)$ \\
\hline $0.115^{* *}$ & $0.265^{* *}$ & $0.151 * *$ \\
\hline$(0.012)$ & $(0.023)$ & $(0.026)$ \\
\hline $0.134 * *$ & $0.176^{* *}$ & $0.042 *$ \\
\hline$(0.013)$ & $(0.016)$ & $(0.020)$ \\
\hline $0.152 * *$ & $0.393 * *$ & $0.242 * *$ \\
\hline$(0.019)$ & $(0.024)$ & $(0.030)$ \\
\hline $0.156^{* *}$ & $0.220 * *$ & $0.064 * *$ \\
\hline$(0.009)$ & $(0.012)$ & $(0.015)$ \\
\hline $0.055^{* *}$ & $0.080 * *$ & 0.025 \\
\hline$(0.009)$ & $(0.014)$ & $(0.017)$ \\
\hline $0.075^{* *}$ & $0.117^{* *}$ & $0.042^{*}$ \\
\hline$(0.010)$ & $(0.014)$ & $(0.017)$ \\
\hline $0.088 * *$ & $0.186^{* *}$ & $0.098 * *$ \\
\hline$(0.009)$ & $(0.014)$ & $(0.017)$ \\
\hline $0.107 * *$ & $0.063 * *$ & $-0.043 * *$ \\
\hline$(0.008)$ & $(0.012)$ & $(0.014)$ \\
\hline $0.041 * *$ & $0.053 * *$ & 0.011 \\
\hline$(0.008)$ & $(0.011)$ & $(0.014)$ \\
\hline $0.152 * *$ & $0.118^{*}$ & -0.034 \\
\hline$(0.028)$ & $(0.058)$ & $(0.064)$ \\
\hline $0.021^{\circ}$ & $0.097 * *$ & $0.076 * *$ \\
\hline$(0.011)$ & $(0.013)$ & $(0.018)$ \\
\hline $0.029 * *$ & $0.148 * *$ & $0.118^{* *}$ \\
\hline$(0.011)$ & $(0.018)$ & $(0.021)$ \\
\hline $0.094 * *$ & $0.173 * *$ & $0.079 *$ \\
\hline$(0.012)$ & $(0.031)$ & $(0.034)$ \\
\hline $0.068 * *$ & $0.044 * *$ & $-0.025^{\circ}$ \\
\hline$(0.008)$ & $(0.012)$ & $(0.014)$ \\
\hline $0.062 * *$ & $0.051 * *$ & -0.011 \\
\hline$(0.011)$ & $(0.014)$ & $(0.018)$ \\
\hline$-0.034 * *$ & 0.008 & $0.043 * *$ \\
\hline$(0.011)$ & $(0.013)$ & $(0.017)$ \\
\hline 0.033 & 0.021 & -0.011 \\
\hline$(0.021)$ & $(0.030)$ & $(0.036)$ \\
\hline $0.420 * *$ & $0.403^{* *}$ & -0.017 \\
\hline$(0.009)$ & $(0.012)$ & $(0.015)$ \\
\hline $0.037 * *$ & $0.022 *$ & -0.014 \\
\hline$(0.008)$ & $(0.011)$ & $(0.014)$ \\
\hline $0.064 * *$ & $0.047 * *$ & -0.017 \\
\hline
\end{tabular}


retail sale of automotive fuel (50)

Wholesale trade and commission trade, except of motor vehicles

$(0.009)$

$0.061 *$

$(0.012)$

$(0.015)$

and motorcycles (51)

Hotels and restaurants (55)

Land transport; transport via pipelines (60)

Water transport (61)

Air transport (62)

Supporting and auxiliary transport activities; activities of travel agencies (63)

Post and telecommunications (64)

Financial intermediation, except insurance and pension funding (65)

Insurance and pension funding, except compulsory social security (66)

Activities auxiliary to financial intermediation (67)

Real estate activities (70)

Renting of machinery and equipment without operator and of personal and household goods (71)

Computer and related activities (72)

Research and development (73)

Other businesses activities (74)

$\begin{array}{lll}(0.006) & (0.011) & (0.013)\end{array}$

$\begin{array}{lll}-0.017 & -0.078 * * & -0.061 * *\end{array}$

$\begin{array}{lll}(0.014) & (0.016) \quad(0.021)\end{array}$

$-0.074 * * \quad 0.052 * * \quad 0.126 * *$

$\begin{array}{lll}(0.010) & (0.020) & (0.022)\end{array}$

$0.256 * * \quad 0.304 * * \quad 0.048$

$\begin{array}{lll}(0.026) & (0.041) & (0.048)\end{array}$

$\begin{array}{lll}0.110 & 0.249 * * & 0.138\end{array}$

$\begin{array}{lll}(0.079) & (0.040) & (0.089)\end{array}$

$0.063 * * \quad 0.151 * * \quad 0.089 * *$

$\begin{array}{lll}(0.011) & (0.016) & (0.019)\end{array}$

$0.007 \quad 0.598 * * \quad 0.591 * *$

$\begin{array}{lll}(0.031) & (0.059) \quad(0.066)\end{array}$

$0.197 * * \quad 0.208 * * \quad 0.011$

$\begin{array}{lll}(0.008) & (0.011) \quad(0.013)\end{array}$

$0.146 * * \quad 0.157 * * \quad 0.011$

$\begin{array}{lll}(0.010) & (0.014) \quad(0.017)\end{array}$

$0.061 * * \quad 0.102 * * \quad 0.041$

$\begin{array}{lll}(0.018) & (0.034) \quad(0.038)\end{array}$

$0.084 * * \quad 0.030 \quad-0.053$

$\begin{array}{lll}(0.027) & (0.037) & (0.046)\end{array}$

$\begin{array}{lll}-0.023 & 0.033 & 0.056\end{array}$

$\begin{array}{lll}(0.015) & (0.033) & (0.036)\end{array}$

$0.075^{* *} \quad 0.191 * * \quad 0.117$

$\begin{array}{lll}(0.013) & (0.019) \quad(0.023)\end{array}$

$0.191 * * \quad 0.135 * * \quad-0.056^{\circ}$

$\begin{array}{lll}(0.021) & (0.025) \quad(0.033)\end{array}$

$0.064 * * \quad 0.128 * * \quad 0.063 * *$

$\begin{array}{lll}(0.008) & (0.011) & (0.014)\end{array}$

$\begin{array}{lll}0.075 & 0.170 & 0.056\end{array}$

Means

0.075

0.097

0.026

Average difference for the 15 worse-paying industries

$83.3 \% \quad 83.3 \% \quad 50.0 \%$

$0.783 * * \quad 0.934 * * \quad 0.253$

$0.749 * * 0.939 * * \quad 0.471 * *$

Correlation between OLS and QR coefficients (Pearson)

Notes: Industry wage coefficients are estimated on the basis of equation (1) where the dependent variable is the ln of individual gross hourly wages including annual bonuses. Bootstrapped standard errors are reported between brackets (1000 iterations). $* * / * / 0$ : coefficient significant at the 1,5 and 10 per cent level, respectively. 
APPENDIX 11: Correlation between Industry Wage Differentials and Industry Profitability along the Conditional Wage distribution.

\begin{tabular}{|c|c|c|c|c|}
\hline & & & Nace 2-digit & Nace 3-digit \\
\hline \multirow[t]{6}{*}{1995} & \multirow[t]{2}{*}{ OLS } & Pearson & $0.488^{* *}$ & $0.502 * *$ \\
\hline & & Spearman & $0.477 * *$ & $0.573 * *$ \\
\hline & \multirow[t]{2}{*}{ Q10 } & Pearson & $0.590 * *$ & \multirow{2}{*}{ / } \\
\hline & & Spearman & $0.544 * *$ & \\
\hline & \multirow[t]{2}{*}{ Q90 } & Pearson & $0.369^{*}$ & \multirow{2}{*}{ / } \\
\hline & & Spearman & $0.443 * *$ & \\
\hline \multirow[t]{6}{*}{2002} & \multirow[t]{2}{*}{ OLS } & Pearson & $0.580 * *$ & $0.360 * *$ \\
\hline & & Spearman & $0.589 * *$ & $0.445 * *$ \\
\hline & \multirow[t]{2}{*}{ Q10 } & Pearson & $0.393^{*}$ & \multirow{2}{*}{ / } \\
\hline & & Spearman & $0.498 * *$ & \\
\hline & \multirow[t]{2}{*}{ Q90 } & Pearson & $0.603 * *$ & \multirow{2}{*}{ l } \\
\hline & & Spearman & $0.590 * *$ & \\
\hline
\end{tabular}

Notes: Data on industry profitability are drawn from the Structure of Business Survey. The industry profitability has been estimated by the industry level gross operating surplus per employee. Industry wage differentials have been computed on the basis of equation (1) where the dependent variable is the ln of gross hourly wages including annual bonuses. $* * / * / 0$ : coefficient significant at the 1,5 and 10 per cent level, respectively.

\section{APPENDIX 12: Estimated Industry Wage Differentials against Industry Profitability, Including Annual Bonuses, Nace 3-digit (SES 1995, 2002)}

\begin{tabular}{lcccc}
\hline & $1995(\mathrm{OLS})$ & $2002(\mathrm{OLS})$ & Pooled (OLS) & Fixed Effect \\
\hline Intercept & $-0.053^{* *}$ & $-0.035^{* *}$ & $-0.044^{* *}$ & 0.000 \\
& $(0.010)$ & $(0.009)$ & $(0.009)$ & $(0.011)$ \\
Profits-per-worker & $1.77^{* *}$ & $0.96^{* *}(0.209)$ & $1.34^{* *}$ & -0.51 \\
(millions of EUR ) & $(0.251)$ & & $(0.164)$ & $(0.452)$ \\
Dummy for 1995 & $/$ & $/$ & Reference & $/$ \\
Dummy for 2002 & $/$ & $/$ & -0.001 & $/$ \\
& & & $(0.011)$ & 1.27 \\
F-test & $49.72^{* *}$ & $21.03^{* *}$ & $33.42^{* *}$ & 0.197 \\
Adjusted R & 0.270 & 0.124 & 0.191 & 276
\end{tabular}

Notes: Industry wage differentials (at the Nace 3-digit level) are the dependent variable. They have been computed on the basis of equation (1) where the explained variable is the ln of gross hourly wage including annual bonuses. The industry profitability has been estimated by the industry level gross operating surplus per employee. White (1980) heteroscedasticity-consistent standard errors are reported between brackets. $* * / * / 0$ : coefficient significant at the 1,5 and 10 per cent level, respectively. 
APPENDIX 13: Estimated Industry Wage Differentials against Industry Profitability, Including Annual Bonuses, Nace 2-digit (SES 1995, 2002)

\begin{tabular}{|c|c|c|c|c|}
\hline & 1995 (OLS) & $2002(\mathrm{OLS})$ & Pooled (OLS) & Fixed Effect \\
\hline Intercept & $\begin{array}{l}-0.027 \\
(0.020)\end{array}$ & $\begin{array}{c}-0.037^{*} \\
(0.017)\end{array}$ & $\begin{array}{c}-0.020 \\
(0.016)\end{array}$ & $\begin{array}{c}0.029^{\circ} \\
(0.015)\end{array}$ \\
\hline $\begin{array}{l}\text { Profits-per-worker } \\
\text { (millions of EUR ) }\end{array}$ & $\begin{array}{l}1.96 * * \\
(0.57)\end{array}$ & $\begin{array}{l}1.55^{* *} \\
(0.32)\end{array}$ & $\begin{array}{l}1.67 * * \\
(0.29)\end{array}$ & $\begin{array}{l}-0.42 \\
(0.49)\end{array}$ \\
\hline Dummy for 1995 & l & / & Reference & l \\
\hline Dummy for 2002 & l & l & $\begin{array}{l}-0.021 \\
(0.020)\end{array}$ & l \\
\hline F-test & $12.02 * *$ & $23.52 * *$ & $16.88 * *$ & 0.73 \\
\hline Adjusted $\mathrm{R}^{2}$ & 0.225 & 0.372 & 0.292 & 0.300 \\
\hline Number of observations & 39 & 39 & 78 & 78 \\
\hline
\end{tabular}

Notes: Industry wage differentials (at the Nace two-digit level) are the dependent variable. They have been computed on the basis of equation (1) where the explained variable is the ln of gross hourly wage including annual bonuses. The industry profitability has been estimated by the industry level gross operating surplus per employee. White (1980) heteroscedasticity-consistent standard errors are reported between brackets. $* * / * / 0$ : coefficient significant at the 1,5 and 10 per cent level, respectively.

APPENDIX 14: Estimated Industry Wage Differentials against Industry Profitability, Excluding Annual Bonuses, Nace 2-digit (SES 1995, 1999, 2002)

\begin{tabular}{lccccc}
\hline & $1995(\mathrm{OLS})$ & $1999(\mathrm{OLS})$ & $2002(\mathrm{OLS})$ & Pooled (OLS) & Fixed Effect \\
\hline Intercept & -0.016 & $-0.037^{*}$ & $-0.029^{*}$ & -0.014 & $0.033^{* *}$ \\
& $(0.017)$ & $(0.015)$ & $(0.012)$ & $(0.012)$ & $(0.009)$ \\
Profits-per-worker & $1.46^{* *}$ & $1.82^{* *}$ & $1.15^{* *}$ & $1.38^{* *}$ & $-0.71^{*}$ \\
(millions of EUR ) & $(0.48)$ & $(0.41)$ & $(0.23)$ & $(0.20)$ & $(0.30)$ \\
Dummy for 1995 & $/$ & $/$ & $/$ & Reference & $/$ \\
Dummy for 1999 & $/$ & $/$ & $/$ & -0.011 & $/$ \\
& & & & $(0.016)$ & $/$ \\
Dummy for 2002 & $/$ & $/$ & & -0.022 & $(0.016)$ \\
\hline F-test & $9.34^{* *}$ & $19.72^{* *}$ & $23.91^{* *}$ & $15.75^{* *}$ & $5.61^{*}$ \\
Adjusted R & 0.18 & 0.33 & 0.376 & 0.276 & 0.283 \\
Number of observations & 39 & 39 & 39 & 117 & 117 \\
\hline
\end{tabular}

Notes: Industry wage differentials (at the Nace two-digit level) are the dependent variable. They have been computed on the basis of equation (1) where the explained variable is the ln of gross hourly wage excluding annual bonuses. The industry profitability has been estimated by the industry level gross operating surplus per employee. White (1980) heteroscedasticity-consistent standard errors are reported between brackets. $* * / * / 0$ : coefficient significant at the 1,5 and 10 per cent level, respectively. 
APPENDIX 15: Estimated Industry Wage Differentials against Industry Profitability along the Distribution, Including Annual Bonuses, Nace 2-digit (SES 1995, 2002)

\begin{tabular}{|c|c|c|c|c|c|c|c|c|}
\hline \multirow[b]{3}{*}{ Intercept } & \multicolumn{4}{|c|}{ Q10 } & \multicolumn{4}{|c|}{ Q90 } \\
\hline & $\begin{array}{c}1995 \\
(\mathrm{OLS})\end{array}$ & $\begin{array}{c}2002 \\
\text { (OLS) }\end{array}$ & $\begin{array}{c}\text { Pooled } \\
\text { (OLS) }\end{array}$ & $\begin{array}{l}\text { Fixed } \\
\text { effect }\end{array}$ & $\begin{array}{l}1995 \\
(\mathrm{OLS})\end{array}$ & $\begin{array}{c}2002 \\
\text { (OLS) }\end{array}$ & $\begin{array}{l}\text { Pooled } \\
\text { (OLS) }\end{array}$ & $\begin{array}{l}\text { Fixed } \\
\text { effect }\end{array}$ \\
\hline & $\begin{array}{l}-0.044 \\
(0.016)\end{array}$ & $\begin{array}{l}-0.016 \\
(0.017)\end{array}$ & $\begin{array}{l}-0.024^{\circ} \\
(0.014)\end{array}$ & $\begin{array}{c}0.011 \\
(0.014)\end{array}$ & $\begin{array}{c}0.022 \\
(0.027)\end{array}$ & $\begin{array}{l}-0.046^{*} \\
(0.019)\end{array}$ & $\begin{array}{c}-0.020 \\
(0.0194)\end{array}$ & $\begin{array}{c}0.033 \\
(0.021)\end{array}$ \\
\hline $\begin{array}{l}\text { Profits-per-worker } \\
\text { (millions of EUR) }\end{array}$ & $\begin{array}{c}2.05 * * \\
(0.46)\end{array}$ & $\begin{array}{l}085 * * \\
(0.32)\end{array}$ & $\begin{array}{l}1.21^{* *} \\
(0.26)\end{array}$ & $\begin{array}{l}-0.06 \\
(0.47)\end{array}$ & $\begin{array}{c}1.85^{*} \\
(0.75)\end{array}$ & $\begin{array}{l}1.73 * * \\
(0.37)\end{array}$ & $\begin{array}{c}1.77 \\
(0.36)\end{array}$ & $\begin{array}{l}-0.52 \\
(0.69)\end{array}$ \\
\hline Dummy for 1995 & I & / & Reference & / & l & / & Reference & / \\
\hline Dummy for 2002 & l & l & $\begin{array}{l}-0.004 \\
(0.018)\end{array}$ & / & l & I & $\begin{array}{l}-0.027 \\
(0.025)\end{array}$ & I \\
\hline F-test & $20.28 * *$ & $7.24 * *$ & $10.68 * *$ & 0.02 & $6.13 *$ & $22.15 * *$ & $12.18 * *$ & 0.58 \\
\hline Adjusted $\mathrm{R}^{2}$ & 0.337 & 0.138 & 0.199 & 0.219 & 0.119 & 0.352 & 0.223 & 0.231 \\
\hline $\begin{array}{l}\text { Number of } \\
\text { observations }\end{array}$ & 39 & 40 & 79 & 79 & 39 & 40 & 79 & 40 \\
\hline
\end{tabular}

Notes: Industry wage differentials (at the Nace two-digit level) are the dependent variable. They have been computed on the basis of equation (1) where the explained variable is the ln of gross hourly wage including annual bonuses. The industry profitability has been estimated by the industry level gross operating surplus per employee. White (1980) heteroscedasticity-consistent standard errors are reported between brackets. $* * / * / 0$ : coefficient significant at the 1,5 and 10 per cent level, respectively. 
APPENDIX 16: Earnings Equations, with and without Profits (SES-SBS 1995)

\begin{tabular}{|c|c|c|}
\hline Variables/Models: & $\begin{array}{c}\text { OLS } \\
\text { (without profits) }\end{array}$ & $\begin{array}{c}\text { 2SLS } \\
\text { (with instrumented } \\
\text { profits) }\end{array}$ \\
\hline Intercept & $\begin{array}{l}5.755^{* *} \\
(0.044)\end{array}$ & $\begin{array}{c}5.523 * * \\
(0.076)\end{array}$ \\
\hline Profits-per-worker $(\ln )^{\mathrm{a}}$ & / & $\begin{array}{l}0.063 * * \\
(0.005)\end{array}$ \\
\hline \multicolumn{3}{|l|}{ Education: } \\
\hline Primary or no degree & Reference & Reference \\
\hline Lower secondary & $\begin{array}{c}0.045 * * \\
(0.005)\end{array}$ & $\begin{array}{c}0.047 * * \\
(0.010)\end{array}$ \\
\hline General upper secondary & $\begin{array}{l}0.143 * * \\
(0.006)\end{array}$ & $\begin{array}{l}0.144 * * \\
(0.012)\end{array}$ \\
\hline Technical/Artistic/Prof. upper secondary & $\begin{array}{l}0.143 * * \\
(0.006)\end{array}$ & $\begin{array}{l}0.143 * * \\
(0.011)\end{array}$ \\
\hline Higher non university short type, higher artistic training & $\begin{array}{l}0.259 * * \\
(0.008)\end{array}$ & $\begin{array}{l}0.252 * * \\
(0.014)\end{array}$ \\
\hline University and non-university higher education, long type & $\begin{array}{l}0.419 * * \\
(0.010)\end{array}$ & $\begin{array}{c}0.414 * * \\
(0.018)\end{array}$ \\
\hline Post-graduate & $\begin{array}{l}0.587 * * \\
(0.031)\end{array}$ & $\begin{array}{l}0.583 * * \\
(0.047)\end{array}$ \\
\hline Prior experience: & & \\
\hline Simple & $\begin{array}{l}0.017 * * \\
(0.001)\end{array}$ & $\begin{array}{l}0.016 * * \\
(0.001)\end{array}$ \\
\hline Squared $/ 10^{2}$ & $\begin{array}{c}-0.040 * * \\
(0.008)\end{array}$ & $\begin{array}{c}-0.037 * * \\
(0.009)\end{array}$ \\
\hline Cubed $/ 10^{4}$ & $\begin{array}{l}0.026^{\circ} \\
(0.015)\end{array}$ & $\begin{array}{c}0.020 \\
(0.016)\end{array}$ \\
\hline Seniority in the company: & & \\
\hline Simple & $\begin{array}{l}0.019 * * \\
(0.001)\end{array}$ & $\begin{array}{l}0.019 * * \\
(0.001)\end{array}$ \\
\hline Squared $/ 10^{2}$ & $\begin{array}{c}-0.025 * * \\
(0.002)\end{array}$ & $\begin{array}{c}-0.024 * * \\
(0.003)\end{array}$ \\
\hline Hours paid $(\ln )$ & $\begin{array}{c}-0.032 * * \\
(0.008)\end{array}$ & $\begin{array}{c}-0.056^{* *} \\
(0.013)\end{array}$ \\
\hline Bonus for shift work, night work and/or weekend work (Yes) & $\begin{array}{l}0.059 * * \\
(0.004)\end{array}$ & $\begin{array}{l}0.059 * * \\
(0.008)\end{array}$ \\
\hline Overtime paid (Yes) & $\begin{array}{l}0.025 * * \\
(0.005)\end{array}$ & $\begin{array}{l}0.016 * \\
(0.008)\end{array}$ \\
\hline Contract: & & \\
\hline Unlimited-term employment contract & Reference & Reference \\
\hline Limited-term employment contract & $\begin{array}{c}-0.049 * * \\
(0.009)\end{array}$ & $\begin{array}{c}-0.059 * * \\
(0.014)\end{array}$ \\
\hline Apprentice/Trainee contract & $\begin{array}{c}-0.579 * * \\
(0.129)\end{array}$ & $\begin{array}{c}-0.598 * * \\
(0.177)\end{array}$ \\
\hline Other employment contract & $\begin{array}{c}-0.092 * * \\
(0.020)\end{array}$ & $\begin{array}{c}-0.072 * * \\
(0.024)\end{array}$ \\
\hline Female (Yes) & $\begin{array}{c}-0.123 * * \\
(0.004)\end{array}$ & $\begin{array}{c}-0.120 * * \\
(0.007)\end{array}$ \\
\hline Occupation (22 dummies) & Yes & Yes \\
\hline Region: & & \\
\hline Brussels & Reference & Reference \\
\hline Wallonia & $\begin{array}{c}-0.022 * * \\
(0.006)\end{array}$ & $\begin{array}{l}-0.009 \\
(0.014)\end{array}$ \\
\hline Flanders & $\begin{array}{c}-0.046^{* *} \\
(0.005)\end{array}$ & $\begin{array}{c}-0.036^{* *} \\
(0.012)\end{array}$ \\
\hline Supervises the work of co-workers (Yes) & $\begin{array}{l}0.124 * * \\
(0.006)\end{array}$ & $\begin{array}{l}0.129 * * \\
(0.009)\end{array}$ \\
\hline
\end{tabular}


Size of the establishment $(\ln )$

Level of wage bargaining

CA only at the national and/or sectoral level

CA at the company level

$\begin{array}{cc}\text { Reference } & \text { Reference } \\ 0.034^{* *} & 0.029 * * \\ (0.005) & (0.010) \\ -0.004 * & -0.014 \\ (0.006) & (0.013) \\ \text { Yes } & \text { Yes } \\ \text { No } & \text { Yes } \\ / & 1,501 \\ / & 3.497 \\ 0.714 & (0.174) \\ 275.2 * * & 0.712 \\ 34,972 & 512.1 * * \\ \end{array}$

Other

Notes: The dependent variable is the (Naperian) logarithm of the individual gross hourly wages (including annual bonuses). White (1980) heteroscedasticity consistent standard errors are reported between brackets. Group effects estimations use the correction for common variance components within groups proposed by Greenwald (1983) and Moulton (1990). Instruments for profits include per capita firm level value added (at factor costs) and per capita total amount of goods and services purchased by the firm. ${ }^{\text {a }}$ Approximated by the firm annual gross operating surplus per worker. ${ }^{\mathrm{b}} N R^{\prime 2}$ and associated ( $p$-value). $* * / * /{ }^{\circ}$ : coefficient significant at the 1,5 and $10 \%$, respectively. 
APPENDIX 17: Inter-Industry Wage Differentials and their Dispersion, Nace 3-digit, with and without Profits (SES-SBS 1995)

Industry (NACE 2-digit):

Quarrying of stone (141) for profits

Quarrying of sand and clay (142)

$(0.020)$

(instrumented) profits ${ }^{\mathrm{b}}$

Mining of chemical and fertiliser minerals (143)

Other mining and quarrying n.e.c. (145)

$(0.031)$

$-0.070^{\circ}$

0.002

Production, processing and preserving of meat and meat products

(151)

Processing and preserving of fish and fish products (152)

Processing and preserving of fruit and vegetables (153)

Manufacture of vegetable and animal oils and fats (154)

Manufacture of dairy products (155)

Manufacture of grain mill products, starches and starch products (156)

Manufacture of prepared animal feeds (157)

Manufacture of other food products (158)

$-0.199 * *$

$(0.022)$

$(0.040)$

0.050

$(0.041)$

0.019

$-0.282 * *$

(0.011)

(0.013)

$-0.003$

$-0.019$

(0.024)

$(0.022)$

$-0.082 * *$

$(0.012)$

(0.044)

$0.046^{*}$

$-0.128^{* *}$

$(0.019)$

(0.030)

0.002

$-0.040$

(0.012)

$(0.034)$

0.092 **

$-0.016$

(0.019)

(0.025)

0.030

$-0.011$

$(0.019)$

(0.048)

$0.026^{\circ}$

0.046

$(0.015)$

$(0.028)$

$-0.042 * *$

Manufacture of beverages (159)

$(0.013)$

$(0.034)$

Manufacture of tobacco product (160)

$0.033^{\circ}$

$-0.110^{* *}$

$(0.019)$

$(0.028)$

$-0.153 * *$

Preparation and spinning of textile fibres (171)

$(0.020)$

$-0.104 * *$

$(0.032)$

Textile weaving (172)

$(0.013)$

$-0.143^{* *}$

$(0.046)$

$-0.082^{*}$

$-0.109^{* *}$

Finishing of textiles (173)

Manufacture of made-up textile articles, except apparel (174)

$(0.040)$

$-0.189 * *$

$(0.020)$

$-0.085$

$(0.019)$

$(0.125)$

$-0.058 * *$

$-0.187^{* * *}$

Manufacture of other textiles (175)

$(0.013)$

$(0.017)$

$-0.156^{* *}$

$-0.081 * *$

Manufacture of knitted and crocheted fabrics (176)

$(0.059)$

$(0.021)$

$-0.190 * *$

$-0.180^{* *}$

Manufacture of knitted and crocheted articles (177)

Manufacture of other wearing apparel and accessories (182)

(0.028)

$(0.011)$

$-0.133 * *$

$-0.151^{* *}$

$(0.015)$

$(0.031)$

$-0.108 * *$

$-0.113 * *$

$(0.027)$

Dressing and dyeing of fur; manufacture of articles of fur (183)

$(0.036)$

$-0.105^{* *}$

$-0.099 * *$

$(0.017)$

Tanning and dressing of leather (191)

$(0.019)$

$-0.035$

0.052

$(0.054)$

$(0.037)$

$0.055^{*}$

Manufacture of luggage, handbags and the like, saddlery and harness (192)

Manufacture of footwear (193)

0.008

$(0.021)$

$(0.021)$

$0.140^{* *}$

Sawmilling and planing of wood, impregnation of wood (201)

$-0.082 * *$

$(0.034)$

$(0.018)$

$-0.092 *$

$-0.027$

$(0.040)$

Manufacture of veneer sheets; manufacture of plywood, laminboard,

$(0.021)$

$-0.027$

$(0.052)$ 


\begin{tabular}{|c|c|}
\hline$-0.045 * *$ & -0.030 \\
\hline$(0.012)$ & $(0.020)$ \\
\hline 0.018 & 0.009 \\
\hline$(0.032)$ & $(0.079)$ \\
\hline$-0.079 *$ & -0.001 \\
\hline$(0.033)$ & $(0.021)$ \\
\hline $0.186^{* *}$ & $0.141 * *$ \\
\hline$(0.017)$ & $(0.042)$ \\
\hline $0.028^{*}$ & 0.012 \\
\hline$(0.011)$ & $(0.042)$ \\
\hline 0.019 & -0.037 \\
\hline$(0.017)$ & $(0.047)$ \\
\hline $0.109 * *$ & $0.117 * *$ \\
\hline (0.009) & $(0.018)$ \\
\hline I & I \\
\hline $0.298 * *$ & $0.211 * *$ \\
\hline$(0.021)$ & $(0.069)$ \\
\hline $0.063^{*}$ & 0.026 \\
\hline$(0.025)$ & $(0.017)$ \\
\hline $0.160 * *$ & $0.079 * *$ \\
\hline$(0.006)$ & $(0.017)$ \\
\hline $0.103 * *$ & 0.041 \\
\hline$(0.034)$ & $(0.048)$ \\
\hline $0.100 * *$ & $0.050^{\circ}$ \\
\hline$(0.019)$ & $(0.030)$ \\
\hline $0.037 * *$ & $-0.035^{*}$ \\
\hline$(0.008)$ & $(0.014)$ \\
\hline-0.010 & $-0.047^{*}$ \\
\hline$(0.014)$ & $(0.023)$ \\
\hline $0.109 * *$ & $0.062 * *$ \\
\hline$(0.014)$ & $(0.022)$ \\
\hline $0.047^{*}$ & 0.034 \\
\hline$(0.019)$ & $(0.040)$ \\
\hline-0.008 & -0.017 \\
\hline$(0.017)$ & $(0.032)$ \\
\hline $0.026^{* *}$ & 0.012 \\
\hline$(0.009)$ & $(0.021)$ \\
\hline-0.017 & -0.025 \\
\hline$(0.012)$ & $(0.024)$ \\
\hline$-0.033^{\circ}$ & 0.009 \\
\hline$(0.018)$ & $(0.034)$ \\
\hline-0.040 & $-0.058 * *$ \\
\hline$(0.027)$ & $(0.018)$ \\
\hline-0.009 & -0.069 \\
\hline$(0.017)$ & $(0.071)$ \\
\hline $0.144 * *$ & 0.018 \\
\hline$(0.040)$ & $(0.036)$ \\
\hline $0.048 * *$ & $0.033^{*}$ \\
\hline$(0.011)$ & $(0.016)$ \\
\hline-0.046 & $-0.106^{* *}$ \\
\hline$(0.072)$ & $(0.018)$ \\
\hline $0.112 * *$ & $0.120^{\circ}$ \\
\hline$(0.040)$ & $(0.062)$ \\
\hline $0.173 * *$ & $0.101 * *$ \\
\hline$(0.012)$ & $(0.026)$ \\
\hline $0.080 * *$ & $0.047^{\circ}$ \\
\hline$(0.012)$ & $(0.026)$ \\
\hline $0.067 * *$ & $0.053^{\circ}$ \\
\hline$(0.011)$ & $(0.028)$ \\
\hline
\end{tabular}

Manufacture of other products of wood; manufacture of articles of cork, straw and plaiting materials (205)

Manufacture of pulp, paper and paperboard (211)

Manufacture of articles of paper and paperboard (212)

Publishing (221)

Printing and service activities related to printing (222)

Manufacture of coke oven products (231)

Manufacture of refined petroleum products (232)

Processing of nuclear fuel (233)

Manufacture of basic chemicals (241)

Manufacture of pesticides and other agro-chemical products (242)

Manufacture of paints, varnishes and similar coatings, printing ink and mastics (243)

Manufacture of pharmaceuticals, medicinal chemicals and botanical product (244)

Manufacture of soap and detergents, cleaning and polishing

preparations, perfumes and toilet preparations (245)

Manufacture of other chemical products (246)

Manufacture of man-made fibres (247)

Manufacture of rubber products (251)

Manufacture of plastic products (252)

Manufacture of glass and glass products (261)

Manufacture of non-refractory ceramic goods other than for construction purposes; manufacture of refractory ceramic products (262)

Manufacture of ceramic tiles and flags (263)

Manufacture of bricks, tiles and construction products, in baked clay (264)

Manufacture of cement, lime and plaster (265)

Manufacture of articles of concrete, plaster and cement (266)

Cutting, shaping and finishing of stone (267)

Manufacture of other non-metallic mineral products (268)

Manufacture of basic iron and steel and of ferro-alloys (ECSC) (271)

Other first processing of iron and steel and production of non-ECSC ferro-alloys (273)

Manufacture of basic precious and non-ferrous metals (274) 
Manufacture of tanks, reservoirs and containers of metal;

Manufacture of steam generators, except central heating hot water

Forging, pressing, stamping and roll forming of metal; powder

Treatment and coating of metals; general mechanical engineering

$(0.025)$

$(0.063)$ (285)

Manufacture of cutlery, tools and general hardware (286)

$-0.008$

$-0.015$

$(0.013)$

$(0.042)$

$0.042^{\circ}$

Manufacture of other fabricated metal products (287)

$(0.023)$

(0.040)

$-0.008$

0.021

Manufacture of machinery for the production and use of mechanical

Manufacture of other general purpose machinery (292)

$(0.013)$

(0.030)

$-0.057^{* *}$

$-0.019$

Manufacture of agricultural and forestry machinery (293)

(0.011)

(0.028)

$-0.033 * *$

$-0.006$

Manufacture of machine-tools (294)

(0.011)

(0.057)

0.018

0.008

Manufacture of other special purpose machinery (295)

(0.024)

$-0.076^{* *}$

(0.060)

$(0.007) \quad(0.019)$

Manufacture of weapons and ammunition (296)

$0.134 * *$

(0.012)

$0.121 * *$

Manufacture of domestic appliances n.e.c. (297)

$-0.130 * *$

(0.011)

(0.023)

Manufacture of office machinery and computers (300)

Manufacture of electric motors, generators and transformers (311)

Manufacture of electricity distribution and control apparatus (312)

Manufacture of insulated wire and cable (313)

Manufacture of accumulators, primary cells and primary batteries

Manufacture of lighting equipment and electric lamps (315)

Manufacture of electronic valves and tubes and other electronic 
Manufacture of bodies (coachwork) for motor vehicles; manufacture

Manufacture of parts and accessories for motor vehicles and their

Building and repairing of ships and boats (351)

$(0.010)$

$(0.027)$

$-0.060 * * \quad-0.006$

Manufacture of railway and tramway locomotives and rolling stock

$(0.018)$

(0.039) (352)

0.035

$-0.018$

Manufacture of aircraft and spacecraft (353)

$(0.027)$

$(0.041)$

0.009

0.014

Manufacture of motorcycles and bicycles (354)

(0.010)

$(0.020)$

$-0.056^{\circ}$

$-0.000$

$(0.028)$

Manufacture of other transport equipment n.e.c. (355)

Manufacture of furniture (361)

Manufacture of jewellery and related articles (362)

$-0.245^{* *}$

$(0.020)$

(0.034)

Manufacture of musical instruments (363)

Manufacture of sports goods (364)

Manufacture of games and toys (365)

Miscellaneous manufacturing n.e.c (366)

$(0.034)$

$-0.108 * *$

$(0.034)$

0.046

$(0.071)$

Recycling of metal waste and scrap (371)

Recycling of non-metal waste and scrap (372)

$-0.058 * *$

$(0.017)$

Production and distribution of electricity (401)

Manufacture of gas; distribution of gaseous fuels through mains

(402)

Collection, purification and distribution of water (410)

Site preparation (451)

$$
1
$$

$0.412 * *$

$(0.029)$

1

$-0.053^{\circ}$

$(0.027)$

Building of complete constructions or parts thereof; civil engineering

$-0.034 * *$

(0.008)

0.011

(452)

Building installation (453)

Building completion (454)

$-0.113 * *$

$(0.011)$

$-0.048^{\circ}$

(0.029)

Renting of construction or demolition equipment with operator (455)

Sale of motor vehicles (501)

Maintenance and repair of motor vehicles (502)

$-0.014$

(0.026)

$(0.015)$

$-0.024$

$(0.035)$

$-0.051^{*}$

$-0.070$

$(0.025)$

Sale, maintenance and repair of motorcycles and related parts and

Retail sale of automotive fuel (505)

Wholesale on a fee or contract basis (511)

(0.036)

$-0.198 * *$

Wholesale of food, beverages and tobacco (513) 
Wholesale of non-agricultural intermediate products, waste and scrap (515)

Wholesale of machinery, equipment and supplies (516)

\begin{tabular}{|c|c|}
\hline $0.050 * *$ & 0.039 \\
\hline$(0.010)$ & $(0.024)$ \\
\hline $0.029 * *$ & -0.014 \\
\hline$(0.008)$ & $(0.017)$ \\
\hline 1 & 1 \\
\hline$-0.081 * *$ & -0.040 \\
\hline$(0.012)$ & $(0.026)$ \\
\hline$-0.210 * *$ & $-0.229 * *$ \\
\hline$(0.023)$ & $(0.041)$ \\
\hline$-0.053 *$ & $-0.070 *$ \\
\hline$(0.023)$ & $(0.028)$ \\
\hline$-0.106 * *$ & $-0.074 *$ \\
\hline$(0.012)$ & $(0.034)$ \\
\hline / & 1 \\
\hline$-0.088 * *$ & $-0.083^{*}$ \\
\hline$(0.022)$ & $(0.039)$ \\
\hline 1 & I \\
\hline$-0.153 * *$ & $-0.154 * *$ \\
\hline$(0.028)$ & $(0.046)$ \\
\hline / & / \\
\hline$-0.162 * *$ & -0.051 \\
\hline$(0.024)$ & $(0.067)$ \\
\hline 0.053 & -0.009 \\
\hline$(0.091)$ & $(0.034)$ \\
\hline$-0.164 * *$ & 0.019 \\
\hline$(0.027)$ & $(0.034)$ \\
\hline / & I \\
\hline$-0.072 * *$ & -0.057 \\
\hline$(0.011)$ & $(0.041)$ \\
\hline $0.210 * *$ & $0.136^{*}$ \\
\hline$(0.036)$ & $(0.058)$ \\
\hline $0.280 * *$ & $0.294 * *$ \\
\hline$(0.059)$ & $(0.015)$ \\
\hline $0.127^{*}$ & $0.038 * *$ \\
\hline$(0.055)$ & $(0.011)$ \\
\hline 0.071 & $0.280 * *$ \\
\hline$(0.047)$ & $(0.020)$ \\
\hline / & 1 \\
\hline $0.186 * *$ & $0.096^{*}$ \\
\hline$(0.033)$ & $(0.048)$ \\
\hline $0.188^{* *}$ & $0.219^{\circ}$ \\
\hline$(0.065)$ & $(0.129)$ \\
\hline$-0.063 * *$ & -0.013 \\
\hline$(0.022)$ & $(0.019)$ \\
\hline $0.046 * *$ & $0.094 * *$ \\
\hline$(0.012)$ & $(0.031)$ \\
\hline$-0.143 * *$ & $-0.120 * *$ \\
\hline$(0.029)$ & $(0.009)$ \\
\hline $0.431 * *$ & $0.343 * *$ \\
\hline$(0.035)$ & $(0.035)$ \\
\hline
\end{tabular}

Other wholesale (517)

Retail sale in non-specialised stores (521)

Retail sale of food, beverages and tobacco in specialised stores (522)

Retail sale of pharmaceutical and medical goods, cosmetic and toilet articles (523)

Other retail sale of new goods in specialised store (524)

Retail sale of second-hand goods in stores (525)

Retail sale not in stores (526)

Repair of personal and household goods (527)

Hotels (551)

Camping sites and other provision of short-stay accommodation

(552)

Restaurants (553)

Bars (554)

Canteens and catering (555)

Transport via railways (601)

Other land transport (602)

Sea and coastal water transport (611)

Inland water transport (612)

Scheduled air transport (621)

Non-scheduled air transport (622)

Space transport (623)

Cargo handling and storage (631)

Other supporting transport activities (632)

Activities of travel agencies and tour operators; tourist assistance activities n.e.c. (633)

Activities of other transport agencies (634)

Post and courier activities (641)

Telecommunications (642)

Monetary intermediation (651)

Other financial intermediation (652)

Insurance and pension funding, except compulsory social security (660)

Activities auxiliary to financial intermediation, except insurance and pension funding (671)

Activities auxiliary to insurance and pension funding (672)

Real estate activities with own property (701)

Letting of own property (702) 
Real estate activities on a fee or contract basis (703)

Renting of automobiles (711)

$\begin{array}{cc}/ & / \\ 0.035 & -0.034 \\ (0.035) & (0.037) \\ 0.024 & -0.065^{* *} \\ (0.045) & (0.012) \\ 0.196 * * & -0.045 \\ (0.075) & (0.042) \\ -0.261 * * & -0.328^{* *} \\ (0.024) & (0.016) \\ -0.002 & 0.010 \\ (0.015) & (0.053) \\ 0.011 & 0.025 \\ (0.014) & (0.049) \\ 0.081 * & 0.093 * \\ (0.032) & (0.040) \\ / & / \\ -0.053 & -0.031 * * \\ (0.041) & (0.011) \\ / & / \\ 0.120 * * & 0.082^{*} \\ (0.021) & (0.034) \\ / & / \\ 0.087 * * & \\ (0.011) & 0.081 * * \\ & (0.028)\end{array}$

Data base activities (724)

Maintenance and repair of office, accounting and computing machinery (725)

Other computer related activities (726)

Research and experimental development on natural sciences and engineering (731)

Research and experimental development on social sciences and humanities (732)

Legal, accounting, book-keeping and auditing activities; tax

consultancy; market research and public opinion polling; business

$(0.011)$

$(0.028)$

and management consultancy; holdings (741)

Architectural and engineering activities and related technical

$0.028^{\circ} \quad 0.067$

consultancy (742)

Technical testing and analysis (743)

$(0.015) \quad(0.052)$

$0.156^{* *} \quad 0.180 * *$

$(0.018) \quad(0.038)$

$0.062 * * \quad 0.067^{\circ}$

Advertising (744)

$(0.023) \quad(0.036)$

Labour recruitment and provision of personnel (745) $\quad-0.173 * * \quad-0.099$

$\begin{array}{lcc} & (0.055) & (0.157) \\ \text { Investigation and security activities (746) } & -0.190^{* *} & -0.004\end{array}$

$(0.022) \quad(0.025)$

$\begin{array}{lcr}\text { Industrial cleaning (747) } & -0.070^{* *} & 0.040^{*} \\ & (0.010) & (0.018)\end{array}$

Miscellaneous business activities n.e.c (748) $\quad-0.047^{*} \quad-0.062^{*}$

$(0.021) \quad(0.031)$

\begin{tabular}{lcc}
\hline Adjusted $\mathrm{R}^{2}$ of the wage regression & 0.714 & 0.712
\end{tabular}

F-test relative to the estimated wage regression $\quad 275.2^{* *} \quad 512.1^{* *}$

$\begin{array}{lll}\text { F-test relative to the sectoral dummies } & 35.1 * * & 29.2 * *\end{array}$

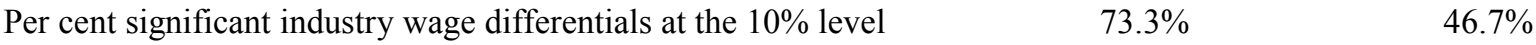

$(110 / 150) \quad(70 / 150)$

$0.692 \quad 0.671$

Range of industry wage differentials

$0.090 \quad 0.062$

Weighted adjusted standard deviation (WASD) of the inter-industry

differentials

Correlation coefficient between industry wage differentials estimated

with and without control for profits:

- Pearson:

- Spearman

$0.783 * *$

Number of industries

150

Number of observations

34,972

150

34,972

Notes: Standard errors of the industry wage differentials, computed according to Zanchi (1998), are reported between brackets. ${ }^{\text {a }}$ Industry wage coefficients are estimated on the basis of equation (1) where the dependent variable is the $\ln$ of individual gross hourly wages including annual bonuses. ${ }^{\mathrm{b}}$ Industry wage coefficients are estimated on the basis of equation (10) where the dependent variable is the $\ln$ of individual gross hourly wages including annual bonuses. Instruments for profits include per capita firm level value added (at factor costs) and per capita total amount of goods and services purchased by the firm. $* * / * /{ }^{\circ}$ : industry wage differential significant at the 1,5 and $10 \%$, respectively. 